\title{
Laparoscopic cholecystectomy in the Netherlands
}

Citation for published version (APA):

Schol, F. P. G. (1995). Laparoscopic cholecystectomy in the Netherlands. [Doctoral Thesis, Maastricht University]. Rijksuniversiteit Limburg. https://doi.org/10.26481/dis.19950622fs

Document status and date:

Published: 01/01/1995

DOI:

10.26481/dis.19950622fs

Document Version:

Publisher's PDF, also known as Version of record

\section{Please check the document version of this publication:}

- A submitted manuscript is the version of the article upon submission and before peer-review. There can be important differences between the submitted version and the official published version of record.

People interested in the research are advised to contact the author for the final version of the publication, or visit the DOI to the publisher's website.

- The final author version and the galley proof are versions of the publication after peer review.

- The final published version features the final layout of the paper including the volume, issue and page numbers.

Link to publication

\footnotetext{
General rights rights.

- You may freely distribute the URL identifying the publication in the public portal. please follow below link for the End User Agreement:

www.umlib.nl/taverne-license

Take down policy

If you believe that this document breaches copyright please contact us at:

repository@maastrichtuniversity.nl

providing details and we will investigate your claim.
}

Copyright and moral rights for the publications made accessible in the public portal are retained by the authors and/or other copyright owners and it is a condition of accessing publications that users recognise and abide by the legal requirements associated with these

- Users may download and print one copy of any publication from the public portal for the purpose of private study or research.

- You may not further distribute the material or use it for any profit-making activity or commercial gain

If the publication is distributed under the terms of Article $25 \mathrm{fa}$ of the Dutch Copyright Act, indicated by the "Taverne" license above, 
Laparoscopic cholecystectomy in The Netherlands 



\section{Laparoscopic cholecystectomy in The Netherlands}

\section{PROEFSCHRIFT}

ter verkrijging van de graad van doctor

aan de Rijksuniversiteit Limburg te Maastricht, op gezag wan de Rector Magnificus, Prof.mr. M.J. Cohen, volgens het besluit wan het College van Dekanen, in het openbaar te verdedigen op donderdag 22 juni 1995 om 16.00 uur

door

Francois Peret Gaston Schol geboren te Amsterdam in 1958 


\section{Promotores}

Prof.dr. G. Kootstra

Prof.dr. D.J. Gouma (Universiteit wan Amsterdam)

\section{Co-promotor}

dr. P.M.N.Y.H. Go (Sint Antonius Ziekenhuis, Nieuwegein)

\section{Beoordelingscommissie}

Prof.dr. R.W. Stockbrïgger (voorzitter)

Prof.dr. B. Janevski

Prof.dr. S. de Lange

Prof.dr. O.T. Terpstra (Rijksuniversiteit Leiden)

Prof.dr. H. Troidl (Universiteit Keulen, Duitsland) 
10

my parents

lnge 


\section{Contents}

CHAPTER 2. Current treatment strategy of gallstone disease 15

$\begin{array}{ll}\text { Introduction } & 17\end{array}$

$\begin{array}{ll}\text { Asymptomatic cholelithiasis } & 17\end{array}$

Symptomatic cholelithiasis $\quad 18$

Complicated gallstone disease $\quad 22$

CHAPTER 3. Technique of the laparoscopic cholecystectomy 31

Endoscopic instruments and supportive equipment 33

Surgical technique of the laparoscopic cholecystectomy 37

Postoperative care after laparoscopic cholecystectomy $\quad 43$

CHAPTER 4. Laparoscopic cholecystectomy in The Netherlands

CHAPTER 5. Risk factors for bile duct injuries in laparoscopic cholecystectomy: Analysis of 49 cases

CHAPTER 6. The outcome of 49 repairs of bile duct injuries after laparoscopic cholecystectomy 
CHAPTER 7. Injuries of major vessel and bowel during 10.000 laparoscopic cholecystectomies in The Netherlands

CHAPTER 8. Laparoscopic cholecystectomy in a surgical training program 95

CHAPTER 9. Treatment of patients with gallstone disease in the laparoscopic cholecystectomy era 107

Introduction 109

Decision tree for treatment of patients with gallstone disease 109

CHAPTER 10. Summary / Samenwatting

Dankwoord

Curriculum vitae 



\section{CHAPTER 1}

Background and aim of the thesis 



\section{Background}

\section{Introduction of the cholecystectomy}

The first cholecystectomy was performed on a 43 year old patient in July 1882 by Carl Langenbuch (1846-1901), chief surgeon at the Lazarus Hospital in Berlin ${ }^{1}$. The preference of Langenbuch to perform a cholecystectomy instead of a cholecystostomy for the treatment of gallstone disease was controversial. He reasoned that the gallbladder should be resected because it originates the gallstones and not just contains them ${ }^{2}$. The discussion about cholecystectomy as acceptable treatment for gallstone disease lasted for many years and its recognition was delayed ${ }^{2}$. With the establishment of general surgery ${ }^{3,4}$ and the introduction of bile duct exploration by Kehr ${ }^{5}$, biliary surgery became an imperative part in the treatment of gallbladder disease based on the ideas of Lamgenbuch and Kehr.

\section{Introduction of laparoscopy}

The approach of the intraabdominal cavity by laparoscopy is a well-known method to physicians since the beginning of the 20 th century 6 . Laparoscopy has become the domain of gynaecologists and was until recently almost totally neglected by general surgeons?.

Development of miniature cameras and more interest of general surgeons in laparoscopy emerged to a new idea to approach and resect the gallbladder.

\section{Introduction of the laparascopic cholecystectomy}

Mühe and Mouret reported both a technique for the treatment of gallbladder stones using a laparoscopic approach in 1986-1987. Mühe described the first laparoscopic cholecystectomy $y^{8,9}$. He was soon followed by Mouret ${ }^{8,10}$.

In 1990 the laparoscopic cholecystectomy was introduced at the University Hospital of Maastricht among several other surgical departments in The Netherlands. Shortly after its introduction, post-graduate courses became available in Maastricht, followed by other centers The Netherlands, to introduce and train surgeons the laparoscopic technique.

The advantages and disadvantages that are claimed for the laparoscopic procedure compared to the open cholecystectomy are increasingly based on prospective randomised trials $^{11,12,13,14}$. Not all these studies reached their endpoint because of a high rate of witdrawal after randomisation and a difficult patient recruitment ${ }^{11,12,13,14}$. The differences in 
favour of laparoscopic cholecystectomy are significant for reduction of postoperative pain. hospital stay and length of convalescence (table 1). Operation time for the laparoscopic approach has not become shorter in these studies as compared to the open cholecystectomy (table 1).

\begin{tabular}{|l|c|c|c|c|}
\hline & $\begin{array}{c}\text { less } \\
\text { postoperative } \\
\text { pain }\end{array}$ & $\begin{array}{c}\text { shorter } \\
\text { hospital stay }\end{array}$ & $\begin{array}{c}\text { earlier } \\
\text { convalescence }\end{array}$ & $\begin{array}{c}\text { longer } \\
\text { operating time }\end{array}$ \\
\hline Barkum et al & no & yes & yes & no \\
\hline Kunz et $\mathrm{al}^{1 / 2}$ & yes & yes & - & no \\
\hline Trondsen et $\mathrm{al}^{1 / 3}$ & yes & yes & yes & yes \\
\hline McMahon et al $\mathrm{I}^{14}$ & yes & yes & yes & yes \\
\hline
\end{tabular}

Table 1. Statistical significance of analysed subjects for laparoscopic compared to open cholecystectomy.

The early introduction of the laparoscopic technique and subsequent laparoscopic courses at the Universily Hospital of Mastricht inspired to an analysis on the results of the introduction of laparoscopic cholecystectomy in The Netherlands as well as Maastricht and the impact of this technique on surgical residential training.

\section{Aim of the thesis}

The introduction of the laparoscopic cholecystectomy was characterized by a warm enthusiasm of many surgeons. In 2 years almost all surgical groups in The Netherlands have adapted to the laparoscopic cholecystectomy.

The aim of this thesis is to analyse the results of the laparoscopic cholecystectomy in The Netherlands during the early phase after introduction of this technique in spring 1990 until January 1993. The major complications which occurred due to laparoscopic cholecystectomy, such as bile duct injuries, great vessel and bowel injuries, are evaluated. An attempt is made to find common denominators leading to major complications. In addition, the implication of introduction of the laparoscopic cholecystectomy is telated to the training program of surgical residents in The Netherlands. 
The department of surgery of the University Hospital Maastricht held 2 successive national surveys on the results of laparoscopic cholecystectomy in The Netherlands covering the first 2 years and the third year after its introduction. Both national surveys were the basis for further in-depth studies on the outcome of the laparoscopic cholecystectomy in The Netherlands.

\section{Chapter distribution}

The results of the studies outlined in this thesis are summarised as follows:

In Chapter 2, the current concept in treatment of patients with uncomplicated and complicated gallstone disease is reviewed. Based on literature, the different modalities of surgical and non-surgical interventions are discussed and evaluated on applicability.

The technique of laparoscopic cholecystectomy, as used in the residential surgical training program of the University Hospital Maastricht and teached throughout all Maastricht courses, is outlined in chapter 3 . Chapter 4 reports the overall results of a national survey over the first 2 years of laparoscopic cholecystectomy in The Netherlands based on 6076 laparoscopic cholecystectomies. Especially safety and efficacy of laparoscopic cholecystectomy in general surgical practice are evaluated. In chapter 5, the aetiology of bile duct injuries due to laparoscopic cholecystectomy is analysed, which were collected during the first national survey in The Netherlands. In this analysis, 49 bile duct injuries are classified in 4 classes depending on severity of the injury. Possible risk factors contributing to the origin of bile duct injuries are identified and correlated with the severity of the injuries. Treatment and outcome of the 49 bile duct injuries are analysed in chapter 6. End-10-end and biliodigestive anastomosis are evaluated for the different types of bile duct injuries. Chapter 7 reports on 15 major vessel and bowel injuries due to laparoscopic cholecystectomy collected during both national surveys. Common factors in the cause of these complications are detected and discussed. Treatment and outcome of these 15 injuires are evaluated. The implementation of laparoscopic cholecystectomy in the residential surgical training program at the University Hospital of Maastricht is analysed in chapter 8. Therefore, the number of (laparoscopic) cholecystectomies performed by residents from 1987-1993 is determined. The outcome of laparoscopic cholecystectomies performed by residents are compared to laparoscopic cholecystectomies by surgeons to 
detect possible differences. The possibilities of laparoscopic cholecystectomy for patients with gallstone disease are discussed in chapter 9. A decision tree is presented, to determine the best treatment for each patient with gallstone disease. The thesis ends with a summary and conclusions. 


\section{References}

1) Hardy KJ. Carl Langenbuch and the Lazarus Hospital: events and circumstances surrounding the first chollecystectomy. Aust $\mathrm{N} Z \mathrm{Z}$ I Surg. 1993; 63: 56-64.

2) van Gullik TM. Langenbuch's cholecystectony, once a remarkably controwersial operation. Neth I Surg. 1986; 38: 138-141.

3) Hamelmann H. The past, present and future of German surgery. Ipn I Surg. 1984; 14: $444-451$.

4) Arianoff AA. History of biliary surgery. Apropos of the centennial of the first cholecystectomy. Acta Chir Belg. 1983; 83:241-252.

5) Braasch JW, Rossi RL. Reconstruction of the biliary tract. Surg Clin North Am. $1985 ; 65: 273-283$.

6) Nagy AG, Poulin EC, Girotii MJ, Litwin DE, Mamazza J. History of laparoscopic surgery. Can I Surg. 1992; 35: 271-274.

7) Rock AJ, Warshaw JR. The history and future of operative laparoscopy. Am J Obstet Gynecol. 1994; 170: 7-11.

8) Mühe E. Laparoskopische Cholezystectomie - Spätergebnisse. Langebecks Arch Chir Suppl. 1991: 416-424.

9) Mühe E. Die erste Cholecystektomie durch das Laparoskop. Langebecks Arch Chir. 1986: 804

10) Mouret P. (not published) Statement in Dubois F. Coeliascopic cholecystectomy. Endoscopic Heute 1990; 1: 30-32.

11) Barkun IS, Barkun AN, Sampalis JS, Fried O, "laylor B, Wexler MJ, Goresky CA, Meakins JL. Randomised controlled trial of laparoscopic versus mini cholecystectomy. Lancet. 1992; 340; 1116-1119.

12) Kunz R, Orth K, Vogel J, Steinacker JM, Meitinger A, Brükner U, Beger HG. Laparoskopische Cholecystektomie versus Mini-Lap-Cholecystektomie. Chirurg. $1992 ; 63: 291-295$.

13) Trondsen $E_{*}$ Reiertsen $O$, Andersen $O K$, Kjarsgaard $P$. Laparoscopic and open cholecystectomy. Eur J Surg. 1993; 159: 217-221.

14) McMahon AJ, Russell IT, Baxter JN, Ross S, Anderson JR, Moman CG, Sunderland G, Galloway D, Ramsay G, O'Dwyer PJ. Laparoscopic versus 
minilaparotomy cholecystectomy: a randomised trial. Lancet. 1994; 343: 135-1138. 
CHAPTER 2

Current treatment strategy of gallstone disease

A review of the literature 



\section{Introduction}

The overall incidence of galstones for the adult population in the Netherlands is approximately 10\%! At an age over 70 years, $15 \%$ of the male and $40 \%$ of the female population have gallstones. In $15 \%-20 \%$ of these persons chotelithiasis is associated with common bile duct stones. In total 1.5 million people are estimated to have cholelithasis in The Netherlands'. Cholecystectomy has been the treatment of choice for gallstone disease since more than a century and almost 14.000 cholecystectomies are annually performed in The Netherlands. In recent years, different new treatments have been introduced for gallstone disease and most of them proved to be useful for particular indications. The introduction of the laparoscopic cholecystectomy instigated to different view on treatment of gallstones $2,3,45$. To have an overview of the current concept in the treatment of gallstones, it is necessary to subdivide the patients with cholelithiasis into 3 clinical catagories:

Asymptomatic cholelithiasis.

Symptomatic cholelithiasis.

Complicated gallstone disease.

\section{Asymptomatic cholelithiasis}

The gallstones in this catagory of patients are detected coincidentally during screening examinations. An older and mone traditional definition of asymptomatic cholelithiasis included coincidentally detected gallstones in patients with nonspecific abdominal complaints ${ }^{6}$. The natural course of patients with asymptomatic or silent gallstones is mild. Only $1-2 \%$ each year will suffer from billiary complaints or complications and this percentage is declining in the years to follow, so that $75 \% .85 \%$ of these patients will remain free of symptoms without any treament, It is not necessary to perform a prophylactic cholecystectomy in patients with asymptomatic cholelithiasis because most of the $15 \%-25 \%$ of patients who develop problems, have biliary complaints before these complications occur. Even if biliary complications do occur as the first symptom, urgent safe treatment is still possible. For distinct groups of asymptomatic patients, however, an elective cholecystectomy should be considered. These groups are more at risk for 
symptomatic disease of have a higher opetative risk if an emergency operation is necessary because of biliary complications. At risk are patients with diabetes mellitus, depression of the immune system, prolonged parenteral nutrition or use of centain drugs. Patients with a diabetes have higher morbidity and mortality at emergency cholecystectomy than patients without diabetes ${ }^{8,5}$. This is probably more related to coincidental cardiovascular and renal problems than 10 the diabetes itself. Therefore, some authors advocate to wait with at cholecystectomy in the diabetic patient until biliary complaints develop ${ }^{810.11}$. Patients who are inmunosupressed by steroids or immuno-incompetent from a neoplasm, have a higher montality rate after cholecystectomy than patients without these risk factors. Prolonged patenteral nutrition and postmenopausal estrogen therapy are accompanied with an increased incidence of cholelithasis due to a lack of gallbladder empinging ${ }^{12,13,14,15}$. Prophylactic cholecystectomy for these special groups is still under discussion.

If gallstones are incidentally found during major abdominal surgery for a non biliary related abdominal disorder, cholecystectomy should be considered. It is reported that up to $45 \%$ of these patients will develop biliary complaints within a year after operation ${ }^{10}$. A prophylactic cholecystectomy or cholecystectomy "én passant", does not increase morbidity and mortality in these patients.

There is no indication for cholecystectomy to prevent the risk of gallbladder carcinoma in patients with silent stones. There is no causative relation between gallstones and cancer. The incidence of gallbladder carcinoma is $1 \%$ each year. However, if a calcified (porcelain) gallbladder is diagnosed, the incidence of gallbladder carcinoma increases up to $25 \%$. In these patients prophylactic cholecystectomy should be performed ${ }^{\text {4.5. }}$.

\section{Symptomatic cholelithiasis}

Patients in this catogory have recurrent complaints of pain. Twenty to thirty percent of theso patients will develop complications of the gallstones in the next $10 \mathrm{~m} 15$ years ${ }^{4.5}$. Therefore, it is indicated to treat these patients for their gallstones. It is important to differentiate this group of patients from patients with gallstones and atypical abdominal complaints. The latter group should be defined as asymptomatic because their symptoms we not related to the bilary system and probably due to other gastro-intestinall disorders. These patients should not be operated. A follow-up study 10 years after cholecystectomy 
showed that cholecystectomy in patients with atypical symptoms leads to a significunt higher risk for post cholecystectomy symptoms than patients operated for typical biliary complaints".

A number of treatments are available for treatment of patients with symptomatic cholelithiasis. Each treatment modality has its indication, succes rate, recurrence rate, morbidity and mortality.

Dissolution with chenodesoxycholic acid (CDCA) or ursodeorycholic acid (UDCA)

Therapy with orally administered bile acids will only be successful in patients with cholesterol gallstones. In the westem world gallstones are in $70 \% .80 \%$ cholesterol stones. Cholesterol stones can be diagnosed by radiolucency on an oral cholecystogram and ultrasonography. Radiolucent stones however contain in about $20 \%$ a low concentration of cholesterol, so that treatment with bile acids will fail in these patients ${ }^{18}{ }^{1 \%}$. Dissolution therapy can be applied on patients of any sex or age. Successtul treatment can only be achieved if the gallstones are relatively small (< $10 \mathrm{~mm}$ ) and the gallbladder is functioning $23,5,20$. The patient must be prepared to swallow bile acid analogues such as CDCA $(8-15 \mathrm{mgr} / \mathrm{kg})$ or LDCA $(7-10 \mathrm{mgr} / \mathrm{kg})$ for 1 or 2 years continuously. A combination of CDCA and UDCA dissolution seems to be more effective compared to a mono-therapy ${ }^{21}$. There is a better response in female and non-obese patients than in male and obese patients ${ }^{22.23}$. In patients selected according to the above mentioned criteria, complete stone dissolution can be achieved in approximately $40 \%-60 \%$ after 2 years of treatment $^{20}$. However, the recurrence rate is $50 \%$ after 5 years, although not all patients with recurrent gallstones become symptomatic $20,24,25,26,27$. Side effects of CDCA treatment are diarthoea in approximately $50 \%$ and temporary elevated serum transaminase lewels in approximately $30 \%$ of the patients ${ }^{23}$. These side effects are rare with UDCA treatment. The effect of bile acids on the liver of the foetus is not yet well known and women should have an adequate contraception during CDCA or UDCA treatment. Oral dissolution therapy is not associated with mortallity.

\section{Methyl Tert Butyl-Ether (MTBE)}

MTBE is a dissolving agent for cholesterol gallstones. Alll patients can be treated with 
MTBE except patients with acute cholecystitis, cholangitis or pancreatitisi other contraindications are coagulopathy, obstruction of the cystic duct and pregnancy. MTBE is preferably administrated through a percutaneous transhepatic catheter in the gallbladder and it dissolves the stones by direct contact. An endoscopic approach via the cystic duct is possible 2829.30 . Proper placement of the catheter in the gallbladder is vital to prevent leakage. The catheter is mostly placed for 2 or 3 days and each day MTBE is administrated during 3-4 hours. Stone dissolution is achieved in $80 \%-90 \%$ of the patients after 12 hours of treatment. Stone debris in the gallbladder is a problem and a high incidence of recurrence can be expected. Side effects such as nausea and womiting are observed. Also transient sedation due to ether is described ${ }^{28.29}$. MTBE treatment is not related with mortality.

\section{Extracorporeal shock-wave lithotripsy (ESWL)}

ESWL can only be applied in $10 \%-15 \%$ of the patients with symptomatic cholelithiasis because of the selection criteria for this treatment $20,24,25,31$. They include a solitary stone with a diameter of less than $2 \mathrm{~cm}$ or 2 or more stones with a total volume equal to a single stone of $2 \mathrm{~cm}$, a functioning gallbladder, no signs of cholecystitis, no obesity, no cardiac problems, no coagulation disorder and no pregnancy. The patients must also be willing to take oral bile acidls during at least 6 months. The first results of the Munich-group with this electrohydraulic device, based on a high voltage spark, were promising ${ }^{33.34}$. A stone clearance of $70 \%-90 \%$ for solitary stones and $40 \%-60 \%$ for multiple stones have been reported $^{35}$. These results could not be confirmed in other studies ${ }^{36,37,38}$. The results, largely depend on pationt sellection and additional length of bile acid treatment ${ }^{36,38}$. Recurrence is almost $10 \%$ at 1 year especially in patients treated for multiple stones and will be considerable higher (30\%) at 5 years ${ }^{39,40}$. Complications of the ESWL treatment are petechiae $(8 \%)$, haematuria $(4 \%)$, biliary pain $(7 \%)$ and pancreatitis $(1 \%)^{344}$. Other side effects are due to the onl bile acids as described earlier. No montality has been described.

\section{Mechanical direct contact techriques for fragmenation}

Mechanical, electrohydraulic, laser and ultrasonic lithotriptors are used for direct fragmentation of gallstones via the percutaneous or endoscopic route ${ }^{4042}$. The safety of these techniques outside centers is still under discussion but most are effective in the 
treatment of large stones.

\section{Open cholecystectomy}

Open cholecystectomy has been the golden standard for more than 100 years and it is still a safe and effective treatment for symptomatic cholelithiasis. A population based study ${ }^{43}$ analysing 42.472 patients during a 12 -month period, showed a morbidity of $14 \%$ and a mortality of $0.17 \%$. In patients younger than 65 years an operation mortality of $0.03 \%$ was reported $^{43}$. Bile duct injuries occured in $0.2 \%$ of the patients. A variant is the so-called mini cholecystectomy, which is an open cholecystectomy using a smaller incision. It is associated with less postoperative pain and earlier recovery than the standard open cholecystectomy ${ }^{44}$. The significance of the mini cholecystectomy seems to be limited after the introduction of the laparoscopic cholecystectomy.

\section{Laparoscopic cholecystectomy}

Laparoscopic cholecystectomy has been accepted as the treatment of choice for symptomatic cholelithiasus and is general surgical practice nowadays ${ }^{45,46,47,45,49}$. This technique can be used regardless type, size, number of stones or function of the gallbladder. Laparoscopic cholecystectomy is safe and efficient as many series have reported ${ }^{45,47,48,49}$. Most of these series are reports from experienced centers and the results in general practice are still under discussion. Conversion to open cholecystectomy occurs in about $5 \%$ and should not be considered as a complication. Morbidity rate is between $2 \%$ $10 \%$. Bule duct injuries are a most serious operation complication and are reported to occur between $0.2 \%-1 \% 45,46,47,48,49,50,51$. This high incidence of bile duct injuries probably reflects the relative inexperience in laparoscopic procedures at that time. However, surveys generally underestimate the incidence of complications of laparoscopic cholecystectomy ${ }^{51,52}$. Bile duct injuries will extensively be analysed in this thesis (chapter 5). Mortality rate of the laparoscopic cholecystectomy is less than $0.2 \%$. Laparoscopic cholecystectorny reduces the postoperative morbidity resulting in a shorter hospital stay and earlier work resumption than the conventional cholecystectomy. Data on the impact of laparoscopic cholecystectomy on the training program of surgical residents are limited. 


\section{Complicated gallstone disease}

\section{Acute cholecystitis}

Acute cholecystitis is mostly treated by early cholecystectomy. This policy is supported by the outcome of randomised trials comparing early versus delayed cholecystectomy for acute cholecystitis ${ }^{3,54}$. A cholecystectomy a froid after 3 months is preferred by some Surgeons, especially when the onset of symptoms is longer than 48 hours ${ }^{54}$. The interwal between onset of symptoms and cholecystectomy ( $<2$ days versus 2-7 days) did not alter the postoperative morbidity and montality after cholecystectomy ${ }^{\text {ss }}$. Cholecystectorny at chaud can therefore be performed safely within at least 7 diays after onset of symptoms. A cholecystectomy a froid should be performed if the onset of symptoms is longer than 7 days and/or infiltration of surrounding gallbladder tissue exists. It is still controversial whether a patient with an acute cholecystitis should be treated by a conventional or laparoscopic approach. Open cholecystectomy is a relatively safe procedure with a morbidity of $10 \%$ and a mortality of $0.5 \%$. A laparoscopic procedure, however, can also be performed relatively safe for acute cholecystitis in experienced hands ${ }^{56}$. One should have a wide experience with the laparoscopic procedure and have a low treshold for conversion to the open technique, when attempting a laparoscopic cholecystectomy for an acute cholecystitis.

For patients with a high operative risk and for critically ill patients in the intensive care unit percutaneous viltrasound guided cholecystostomy under local anaesthesia is a good alternative for an operation ${ }^{57,58}$. It can be followed by a cholangiography wia the catheter and cholecystolithotomy or dissolution with MTBE to prevent biliary peritonitis from a perforated gallbladder. For acalculous cholecystitis which is often accompanied with necrosis of the gallbladder, a cholecystectomy is indicated ${ }^{\text {s }}$.

\section{Gallstome pancreatitis}

Patients with a gallstone pancreatitis should receive an endoscopic retrograde cholangiom pancreaticography (ERCP) and papillotomy within 24 hours, especially for severe pancreatitis or if symptoms increase. This policy resulted in less biliary sepsis as compared to initially conservative treated patients as shown in a recent triat ${ }^{509}$. Other studies support an immediate ERCP in gallstone pancreatitis "AB, "After the symptoms have subsided 5-6 
days after ERCP and papillotomy, Japaroscopic cholecystectomy should be considered to prevent further attacks or acute cholecystitis. In high risk patients surgery should be postponed and only performed if indicated. If an ERCP can not be performed and surgical treatment is indicated one should realise that emergency biliary surgery, within 24 hours of admission, for patients with gallstone pancreatitis, is associated with higher morbidity and mortality as compared to delayed surgery, especially in severe pancreatitis ${ }^{62}$.

\section{Common bile duct stones}

The incidence of bile duct stones after cholecystectomy due to residual and recurrent calculi is $1 \%-2 \%{ }^{63,64}$. For these patients and also high risk patients with the gallbladder in situ an endoscopic sphincterotomy is indicated ${ }^{65}$. For younger patients with choledocholithiasis and the gallbladder stil in situ there are 2 alternatives. Firstly, endoscopic sphincterotomy and subsequent laparoscopic cholecystectomy which is a relatively safe treatment $t_{6,67.68: 69.79}$. Although long term complications after endoscopic sphincterotomy seem to be limited, they are not yet fully understood and therefore, minimum age for sphincterotomy is still set at 50 years. It is also under discussion whether a (laparoscopic) cholecystectomy should be performed routinely after endoscopic sphincterotomy and bile duct stone clearance or only in case of acute cholecystitis or recurrent biliary pain. It is reported, however, that acute cholecystitis appears in about $10 \%$ within 2 years after splincterotomy. A non functioning gallbladder probably is an indication for a cholecystectomy because the incidence of cholecystitis is much higher for this group of patients ${ }^{71}$. Secondly, a laparoscopic cholecystectomy with laparoscopic choledochotomy or stone removal via the cystic duct is possible with a flexible choledochoscope introduced through a $5 \mathrm{~mm}$ trocar opening. This treatment however requires expertise ${ }^{72,73}$. This totally laparoscopic treatment seems to be of interest in younger patients $^{74}$. The succes rate of ERCP is $90 \%-95 \%$ and stone clearance between 80 and $90 \%$ in experienced centers $5^{67,75,76}$. Morbidity respectively mortality are $10 \%$ and $0.5 \%-1 \%$. Stone clearance depends on the size of the calculi and for large stones mechanical crushers, contactlaser or ESWL should be considered ${ }^{30,40,42}$. If all above mentioned treatments have failed, a traditional surgical approach with open choledochotomy with a biliary clrainage procedure has to be performed. This treatment is still relatively safe with a morbidity reported of $8 \%-15 \%$ and a mortality of $0.5 \%-1 \% 77,78,79$. 


\section{Referencess}

1) Thijs $C$, Knipschild P, Engelshoven I wan. The prevalence of gallstone disease in a Dutch Population. Scan J Gastroenterol 1990; 25: 155-160.

2) NIH Consensus Conference. Gallstones and laparoscopic cholecystectomy. JAMA $1993 ; 269: 1018-1024$

3) Strasberg SM, Clavien PA. Overview of therapentic modalities for the treatment of gallstone diserses. Am I Surg. 1993; 165:420-426.

4) Ransohoff DF, Gracie WA. Treatment of gallstones. Ann Intern Med. 1993; 119 : $606-619$

5) Johnston DE, Kaplan MM. Pathogenesis and treatment of gallstones. N Engl J Med. $1993 ; 328: 412-421$.

6) Blumgart LH. Surgery of the Liver and Biliary tract. Churchill Livingston 1988; Vol 1: 525 .

7) Friedman GD. Natural history of asymptomatic and symptomatic gallstones. Am J Surg. 1993; 165: 399-404.

8) Hickman MS, Schwesinger WH, Page CP. Acute cholecystitis in the diabetic. A case-control study of outcome. Arch Surg. 1988; 123:409-411.

9) Ikard RW. Gallstones, cholecystitis and diabetes. Surg Gynecol Obstet. 1990; 171: 528-532.

10) Gibney Ed. Asymptomatic gallstones. Br J Surg. 1990; 77: 368-372.

11) Ransohoff DF, Miller GL, Forsythe SB, Hermann RE. Outcome of acute cholecystitis in patients with diabetes mellitus. Ann Intem Med. 1987; 106:829-832.

12) Pitt HA, King W III, Mann LL, Roslyn IJ, Berquist WE, Ament WE. Increased risk of cholelithasis with prolonged total parenteralnutrition. Am \Surg. 1983; 145 ; 1061.12.

13) Roslyn J., Pitt HA, Mann LL, Fonkalsrud EW, DenBesten L. Parenteral nutrition induced gallbadder disease: A reason for arly cholecystectomy. Am J Surg. 1984; $148: 58-63$.

14) Boston Collaborative Drug Surveillance Program. Surgically confinmed gallbladder disease, venous thromboembolic disease and breast numoursin relation to postmenopausal estrogen therapy. N Engl I Med. 1974; 290: 15-19. 
15) Coronary Drug Project Research Group. Gallbladder disease as a side effeot of drugs influencing lipid metabolism. N Engl J Med. 1977; 296:1185-1190.

16) Ashur H, Siegal B, Olan Y, Adam YG. Calcified gallbladder (porcelain galloladder). Arch Surg. 1978; 113: 594-596.

17) Konsten J, Gouma DJ, Meyenfeldt MF von, Menheere P. Long-term follow-up after open cholecystectomy. Br J Surg. 1993; 80: 100-102.

18) Bell GD, Dowling $\mathrm{RH}$, Whitney $\mathrm{B}$, Sutor DJ. The value of radiology in predicting gallstone type when selecting patients for medical treatment. Gut 1975; 16:359-364.

19) Whiting MJ, Bradley BM, Watts J McK. Chemical and physical properties of gallstones in South Australia: Implications for dissolution treatment. Gut 1983; 24 : 11-15.

20) Schoenfield LJ, Marks $\mathbb{W W}$. Oral and contact dissolution of gallstones. Am I Surg. $1993 ; 165: 427-430$.

21) Phillips RS, Barkin JS. Oral dissolution therapy for cholelithiasis: mix and match. Alru J Gastroenterol. 1990; 85: 1532-1533.

22) Maton PN, Iser JH, Reuben $A$, Saxton HM, Murphy GM, Dowling RH. Ontcome of chenodeoxyxholic acid treatment in 125 patients with radiolucent gallstones. Medicine $1982 ; 61: 86-97$.

23) Schoenfield LJ, Lachin JM. National Co-operative Gallstone Study Group. Chenodiol (chenodeoxycholic acid) for dissolution of gallstones: The National Co-operative Gallstone Study. Ann Int Med. 1981; 95: 257-282.

24) Villanowa $\mathbb{N}$, Bazzoli $F$, Taroni. Gallstone recurrence after successful oral bile acid treatment. A 12-year follow-up study and evaluation of long-term postdissolution treatment. Gastroenterology 1989;97; 726-731.

25) Hood KA, Gleeson D, Ruppin DC, Dowling RH. Gallstone recurrence and its prevention: The British/Belgian gallstone study group's postdissolution triall. Gut $1993 ; 34: 1277-1288$.

26) Thistle JL. Postdissolution gallstone recurrence. A clinical perspective. Dig Dis Sci. 1989; 34: 44S-48S.

27) Cuschieri A. Non-surgicall options for the management of gallstone disease: an overview. Surg Endosc. 1990; 4: 127-131; discussion 136-40.

28) Thistle JL, May GR, Bender CE. Dissolution of cholesterol gallbladder stones by 
methyl tert-butyl ether administered by percutaneous transhepatic catheter. N Engl J Med. $1989 ; 320: 633-639$.

29) Leuschner $M$, Hellstern A, Schmidt $K$, Fisher $H$, Guildütuna S, Hübner $K$. Gallstone dissolution with methyl tert-butyl ether in 120 patients: Effcacy and safely. Dig Sis Sci. 1991; 36: 198-199.

30) Foerster EC, Matek W, Donschke W. Endoscopic retrograde cannulation of the gallbladder: Direct dissolution of gallstones. Gastrointest Endosc. 1990; 36: 444-450.

31) Erpecum KJ van, Stolk MFJ, Berge Henegouwen GP van, Leeuwen M van, Vos A, Obertop H. Is er nog plaats voor niet chirurgische behandeling van cholesterolgalstenen? Ned Tijdschr Geneeskd. 1991; 135: 1569-1573.

32) Waninger $J$, Walz $H$, Salm $R$, Radecke J, Auer T. Laparoscopic cholecystectomy after unsuccessful shock-wave therapy. Surg Laparosc Endosc. 1992; 2: 217-220.

33) Sackmann $M$, Delius $M_{*}$ Sauerbruch $T$, Holl $J$, Weber $W$, Ippisch E, Hagelauer U, Wess $O$, Hepp W, Brendel W, Paumgartner P. Shock-wave lithotripsy of gallbladder stones. The first 175 patients. N Engl J Med. 1988; $318: 393-397$.

34) Sackmann M, Pauletzki J, Sauerbruch T, Holl J, Schellng G, Paumgartner G. The Munich gallbladder lithotripsy study. Results of the first 5 years with $7 \Perp 1$ patients. Ann Int Med. 1991; 114: 290-296.

35) Ponchon T, Barkun AN, Pujol B, Mestas JL, Lambert R. Gallstone disappearance after extracorporeal lithotripsy and oral bile acid dissolution. Gastroenterology 1989; 97: 457-463.

36) Schoenfield LJ, Berci G, Carnoval RL. The effect of ursodiol on the efficacy and safety of extracorporeal shock-wave lithotripsy of gallstones. N Engl J Med. 1990; 323: $1239-1245$.

37) Lockefeer IHM, Oberiop $H$. Gablaassteenvergruizing, een verwachting in gruizels? Ned Tijdschr Geneeskd. 1990; 34: 125-126.

38) Toom R den, Vergunst $H$, Nijs HGT, Brakel K, Laméris IS, Terpstra OT. Schokgolfvergruizing van stenen in de galblaas; de eerste 54 in Rotterdam-Dijkzigt behandelde patienten. Ned Tijdscln Geneeskd. 1990; 135; 1692-1697.

39) Sackmann $M$, Ippisch E, Sauerbruch $T$, Holl J, Brendel W, Paumgartner G. Early gallstone recurrence rate after successful shock-wave therapy. Gastroenterology 1990 ; 98: $392-396$. 
40) Strasberg SM, Clavien PA. Cholecysiolithiasis: Lithotripsy for the 1990s. Hepatology $1992 ; 16: 820-839$.

41) Rawat B, Burhenne HJ. Extracorporeal shock wave lithotripsy of calcified gallstones. Work in progress. Radiology 1990; 175: 667-670.

42) Moody FG. Lithotripsy in the treatment of biliary stones. Am J Surg. 1993; 165: 479-481.

43) Roslyn JJ, Binns GS, Hughes EFX. Open cholecystectomy. A contemporary analysis of 42,474 patients. ann Surg. 1993; 218: 129-137.

44) Assalia A, Schein M, Kopelman D, Hashmonai. Minicholecystectomy vs conventional cholecystectomy: A prospective randomized trial-Implications in the laparoscopic era. World J Surg. 1993; 16: 755-760.

45) The Southern Surgeons Club. A prospective analysis of 1518 laparoscopic cholecystectomies. N Engl J Med. 1991; 324: 1073-1078.

46) Macintyre IMC, Wilson RG. Laparoscopic cholecystectomy. Br J Surg. $1993 ; 80$ : 552-559.

47) Go PMNYH, Schol FPG, Gouma DJ. Laparoscopic cholecystectomy in The Netherlands. Br J Surg. 1993; 80: 1180-1183.

48) Deziel DJ, Millikan KW, Airan MC, Ko ST, Doolas A, Economon SG. Complications of laparoscopic cholecystectomy: Results of a national survey of 4,292 hospitals and analysis of 77,604 cases. Am J Surg. 1993; 165: 9-14.

49) Perissat J,. Laparoscopic cholecystectomy: The European Experience. Am J Surg. 1993; 165: 444-449.

50) Grace PA, Qureshi A, Burke. Selective cholangiography in laparoscopic cholecystectomy. Br J Surg. 1993; 80: 244-246.

51) Gouma DJ, Go PMNYH. Bile duct injury during laparoscopic and conventional cholecystectomy. J Am Coll Surg 1994; 178: 1-5.

52) Branum G, Schmitt C, Baillie J, Suhocki P, Baker M, Davidoff A, Chari R, Cucchiaro G, Murray E, Pappas T, Cotton P, Meyers WC. Management of major biliary complications after laparoscopic cholecystectomy. Ann Surg. 1993; 217: 532 541 .

53) Norrby S, Herlin P, Holmin T. Early or dellayed cholecystectomy in acute cholecystitis. A clinical trial. Br J Surg. 1983; 70: 163-165. 
54) Gouma DH, Obertop H. Acute calculous cholecystitis. What is new in diagnosis and therapy? HPB Surgery 1992; 6: 69-78.

55) Hoppenbrouwer FHAM, Gouma DI. "Vroege" cholecystectomie woor acute cholecystitis; Inwloed van klachtenduur op morbiditeit en sterfte. Ned Tijdsch Genceskd. 1990; 134:2293-2296.

56) Wiesen SM, Unger SW, Barkin JS, Edelman DS, Scott JS, Unger HM. Laparoscopic cholecystectomy: The procedure of choice for acute cholecystitis. Am J of Gastroenterology $1993 ; 88: 334-337$.

57) Meijers $\mathbb{H}$, Overhagen $H$ van, Lanschot JJB van, Laméris JS. percutane galblaasdrainage is een goede behandeling bij patienten met acute cholecystitis en slechte klinische toestand. Ned Tijdsch Geneeskd. 1993; 137: 1965-1968.

58) Vauthey JN, Lerut J, Martine M, Becker CHR, Gertsch PH, Blumgart LH. lindications and limitations of percutaneous cholecystostomy for acute cholecystitis. Surg Gynaecol Obstet. 1993:176:49-54.

59) Fan ST, Lai ECS, Mok FPT, Lo CM, Zheng SS, Wong J. Early treatment of acute biliary pancreatitis by endoscopic papillotomy. $N$ Engl J Med. 1993; 328: 228-232.

60) Neoptolemos JP. Endoscopic sphincterotomy in acute gallstone pancreatitis. Br J Surg. $1993 ; 80: 547-549$.

61) Pellegrini CA. Surgery for gallstone pabereatitis. Am J Surg. 1993; 165: 515-518.

62) Kelly TR, Wagner DS. Gallstone pancreatits: A prospective randomized trial of the timing of surgery. Surg. 1988; 104: 600-603.

63) Glenn F. Retained calculi within the biliary ductal system. Ann Surg. 1974; 179: 528-539.

64) White TT, Bordley J. One per cent incidence of recurrent gallstones six to eight years after manometric cholangiography. Ann Surg. 1978; 188: 562-569.

65) Lai ECS, Mok FPT, Tan ESY, Lo CM, Fan ST, You KT, Wong I. Endoscopic biliary drainage for severe acute cholecystitis. N Engl I Med. 1992; 326: 1582 1586.

66) Martin IG, Curley P, McMahon MJ. Minimally invasive treatment for common bille duct stones. Br J Surg. 1993; 80; 103-106.

67) Cotron PB. Endoscopic retrograde cholangiopancreatography and laparoscopic cholecystectomy. Am J Surg. 1993; 165:474-478.

68) Mo LR, Yau MP, Hwang MH, Lin RC, Kuo JY, Tsai CC. The role of ERCP and 
therapeutic biliary endoscopy in laparoscopic cholecystectony. J Laparoendose Surg. $1993 ; 3: 19-22$.

69) Franceschi D, Brandt C, Margolin D, Szopa B, Ponsky J, Priebe P, Stellato T, Eckhauser ML. The management of common bile duct stones in patients undergoing laparoscopic cholecystectomy. Am Surg. 1993; 59: 525-32.

70) Hawasli A, Lloyd L, Pozios V, Veneri R. The role of endoscopic retrograde cholangio-pancreaticogram in laparoscopic cholecystectomy. Am Surg. 1993; 59: 285-288; discussion 289.

71) Hoolbrook RF, Jacobson FL, Pezzuti RT, Howell DA. Biliary patency imaging after endoscopic retrograde sphincterotomy with the gallbladder in situ. Arch Surg. 1991; 126: 738-742.

72) Phillips EH, Carroll BJ, Randolph Pearlstein A, Daykhovsky L, Fallas MJ. Laparoscopic choledochoscopy and extraction of common bile duct stones. World I Surg. 1993; 17: 22-28.

73) Hunter JG, Soper NJ. Laparoscopic management of bile duct stones. Surg Clin North Am. 1992; 72: 1077-1097.

74) Mitchell SA, Jacyna MR, Chadwick. Common bile duct stones: A controversy revisited. Br J Surg. 1993; 80: 759-760.

75) Barkun JS, Fried GM, Barkun AN, Sigman HH, Hinchey EJ, Garzon J, Wexler MJ, Meakins JL. Cholecystectomy without operative cholangiography. Implications for common bile duct injury and retained common bile duct stones. Ann Surg. 1993; 218: 371-377; discussion 377-379.

76) Johnson AS, Ferrara J, Steinberg SM, Gassen GM, Hollier LH, Flint LM. The role of endoscopic retrograde cholangiopancreatography: sphincterotomy versus common bile duct exploration as a primary technique in the management of choledocholithiasis. Am Surg. 1993; 59: 78-84.

77) Gouma DJ, Konsten J, Soeters PB, Meyenfeldt MF won, Obertop H. Long term follow-up after choledochojejunostomy for bile duct stones with complex clearance of the bile duct. Br J Surg. 1989; 76: 451-453.

78) Panis Y, Fagniez PL, Brisset D, Lacaine F, Levard H, Hay JM \& the French Ass. for Surg. Research. Long term results of choledochododenostomy versus choledochojejunostomy for choledocholithiasis. Surg Gynaecol Obstet. 1993; 177: 33- 
37.

79) Pint HA. Role of open choledochotomy in the treatment of choledocholithiasis. Am I Surg. 1993; $165 ; 483-491$. 


\section{CHAPTER 3}

Technique of the laparoscopic cholecystectomy 



\section{Endoscopic instruments and supportive equipment}

A basic set of endoscopic instruments and equipment is necessary to ensure a smooth progress of the laparoscopic cholecystectomy.

There is a wide variety of endoscopic instruments on the market. One of the decisions a surgeon has to made in advance, is whether to use disposable or reusable instruments. Disposables are more expensive compared to reusable instruments at first sight but cost of cleaning, sharpening and mantaining of the reusable devices has to be taken into account as well. The advantage of disposable instruments is the possibility to obtain a modular system of which the individual instruments fit smoothly and thus aiding to a dynamic laparoscopic procedure. A cost-benefit analysis therefore should be made for each hospital individually.

The basic set for a laparoscopic cholecystectony consists of a Veress needle, two $10 \mathrm{~mm}$ trocars, two $5 \mathrm{~mm}$ trocars, $5 \mathrm{~mm}$ reducer, $10 \mathrm{~mm}$ laparoscope and camera (fig. 1 ).

Also an endoscopic set of instruments is necessary: graspers and dissecting forceps, a pait of scissors, a suction and irrigation probe, a coagulation hook or spatula and a clip applyer (fig.2)

Ideally, supportive equipment is placed on a mobile videocart. The cart should contain a monitor coupled to a video recorder, a camera to fit on the lapartoscope, a light source of at least 250 Watt, an insufflator with a high flow option for the carbon dioxide insufflation and a spare carbon dioxide cylinder (fig.3). Additional are necessary a monopolar electrosurgical unit with foot switch, wall suction and aline infusion bag under pressure to ensure irrigation when needed.

Veress needle

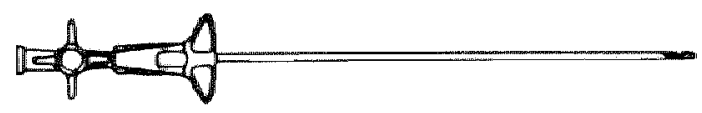

Fig.1. Basic set for laparoscopic cholecystectomy. 
$10 \mathrm{~mm}$ trocar $(2 \mathrm{x})$

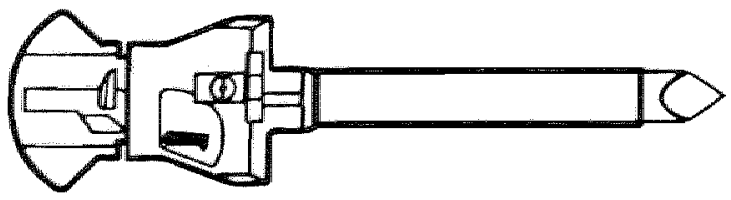

5rom trocar $(2 \mathrm{x})$

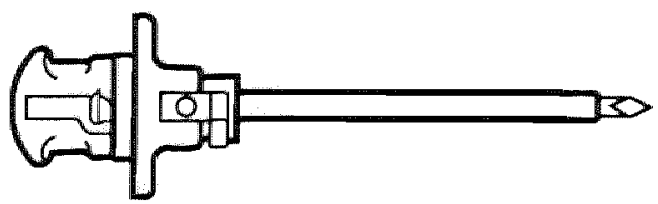

reduceir

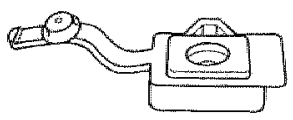

laparoscope

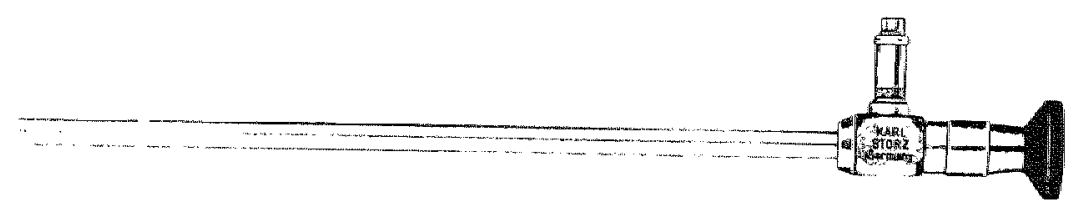

camera
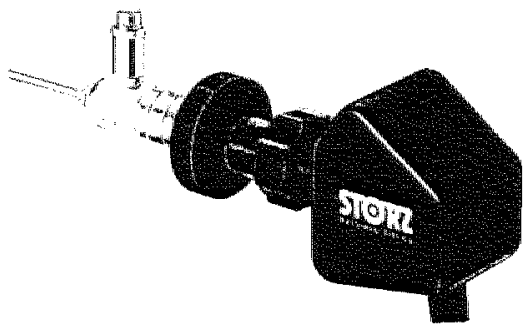

Fig. I. Basic set for laparoscopic cholecystectomy. 
grasper
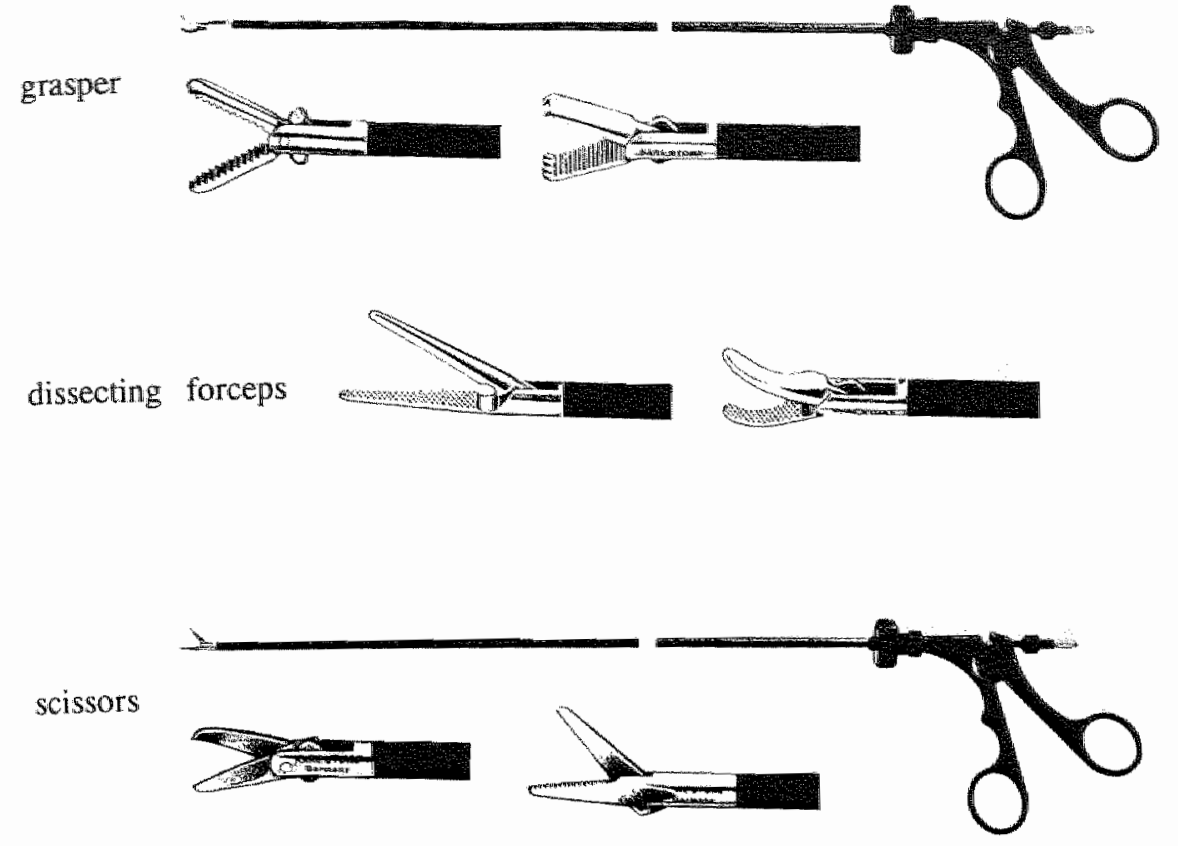

suction/irrigation probe

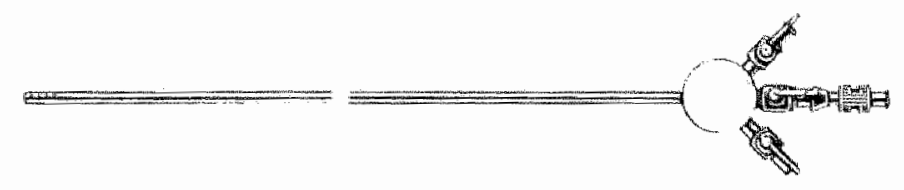

coagulation hook/spalula
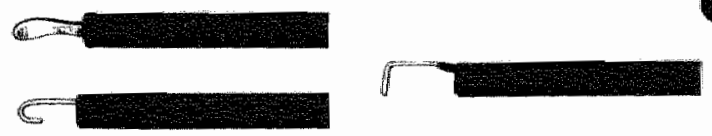

clip applyer

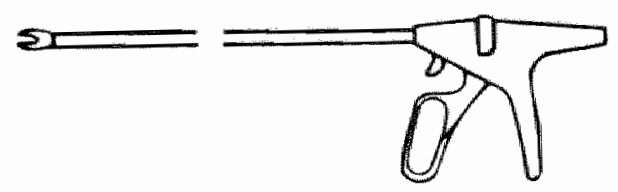

Fig.2. Endoscopic set of instruments. 


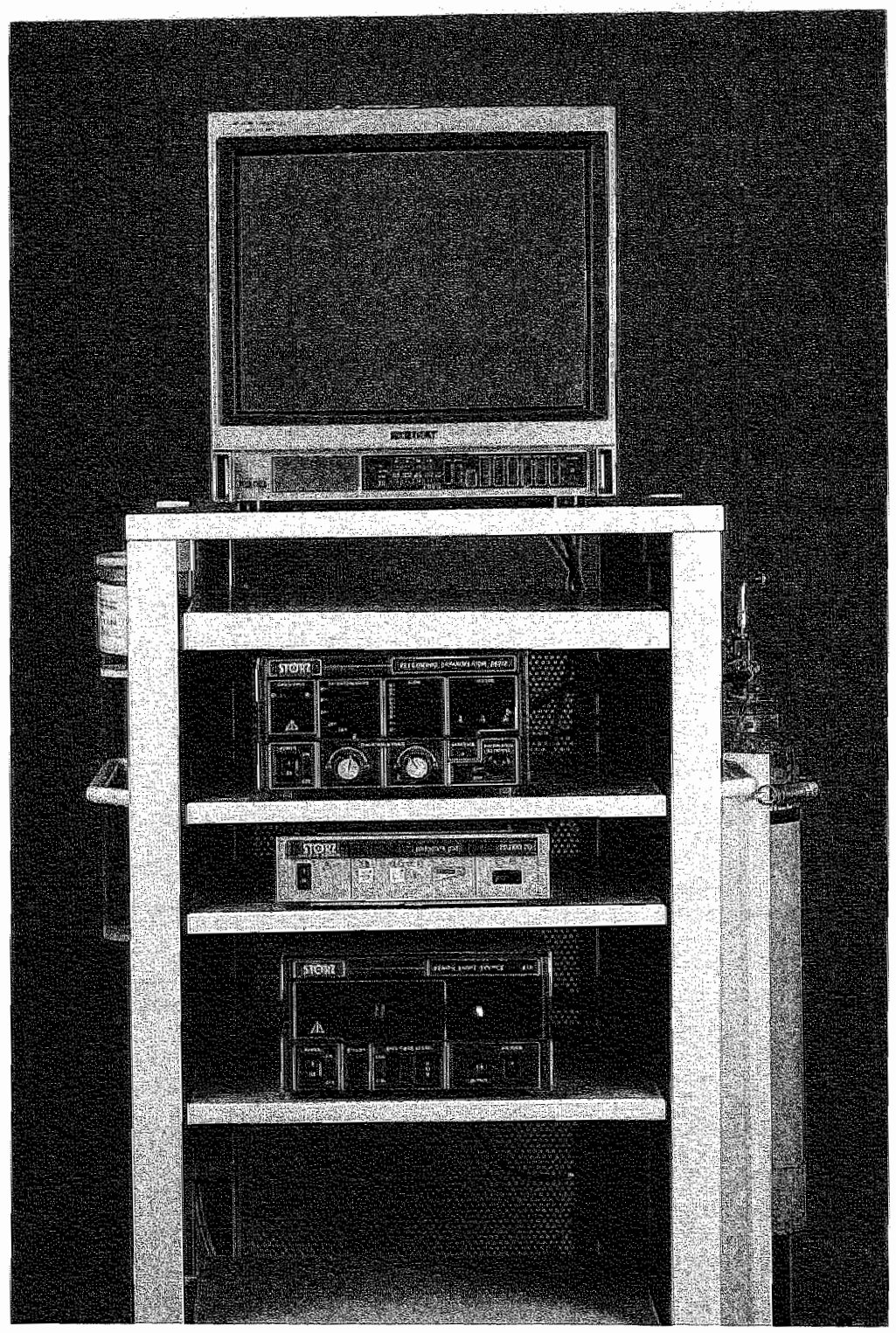

Fign. Mobille videocart with supportive equipment. 


\section{Surgical fechnique of the laparoscopic cholecystectomy}

\section{Preoperative preparation of the patient}

The patient is placed in supine position on the operation table. The cranial part of the table should be appropriate for $x_{\text {w }}$ ray investigation if a cholangiogram is required. A nasogastric tube and a temporary urine catheter are placed. After induction in anaesthesia, the abdomen is prepared and draped, allowing a large enough operation field for conversion to a conventional open cholecystectomy, if necessary. The surgeon's position is at the left and the assistent at the right side of the patient. The OR-nurse and camera operator are positioned next to the assistent respectively surgeon at the more distal part of the operation table.

\section{Intrabdominal introduction of the Veress needle and trocars}

A small semilunar incision of $1.5 \mathrm{~cm}$ is made in the rim under the umbilicus and a Veress needle is introduced after the abdominal wall $\Perp$ s lifted by pulling the umbilical region with the other hand ventrally. The insertion of the Veress needle is approximately $15^{\circ}$ in the caudal direction to prevent major blood vessel injury. During the penetration of the needle through the abdominal wall the fascia of the rectus muscle is reached and some extra force is needed to pass this structure into the abdominal cavity. Reaching the fascia therefore is a warning that the abdominal cavity is nearby. To check if the abdominal cavity is reached, saline is injected through the needle and it should leak into the cavity if the syringe is removed from the Veress needle. Sometimes the abdominal wall has to be moved up and down to create some underpressure to facillitate this. The hose of the insufflator is now attached to the veress needle and the carbon dioxide flow is set on low flow (approximately 1 liter per minute). The occurrence of hypertympanic percussion of the abdomen gives a positive confirmation that pneumoperitoneum is present. Initially, during insulfation the intrabdominal pressure should be low, approximately $5 \mathrm{~mm} \mathrm{Hg}$. After at least 0.5 liter insufflation, the setting can be raised to 8 -10 liter per minute. The intraabdominal pressure should not exceed $12 \mathrm{~mm} \mathrm{Hg}$ and the insufflator must be set accordingly. After reaching the set-pressure, the Veress needle is removed and a $10 \mathrm{~mm}$

trocar is introduced by keeping a firm grip on the abdominal wall at both sides of the umbilical region and pushing the trocar through with a $15^{0}$ tilting towards the lower 
abdomen. The hose of the insuffator is locked to the $10 \mathrm{~mm}$ trocar. The laparoscope with a sterile packed camera connected to it, is now pushed through the sleeve of the trocar (fig.4). Often a blur vision is noted on the monitor as soon as the laparoscope enters the abdominal cavity caused by condense on the lens due to the cold laparoscope coming in a warm and moisture environment.

First a general inspection of the intraabdominal organs with the laparoscope is performed. A preliminary evaluation of the feasibility to resect the gallbladder by laparoscopic means, is made. It should also be checked that the stomach is adequately drained via a preoperatively placed naso-gastric tube. A second $10 \mathrm{~mm}$ trocar is placed approximately 2 fingers under the xyphoid slightly to the right (fig.4). Under visual guidance of the camera the trocar is pushed through the peritoneum on the right-hand site of the hepatoumbilical ligament. If the costal arch is steep, the trocar should be placed a little lower. Two $5 \mathrm{~mm}$ trocars are now introduced under visual control of the camera: The first trocar is placed under the right costal arch in the midclavicular line and the second trocar is inserted in the right frontal axillair line just above the horizontal plane of the umbilical trocar (fig, 4).

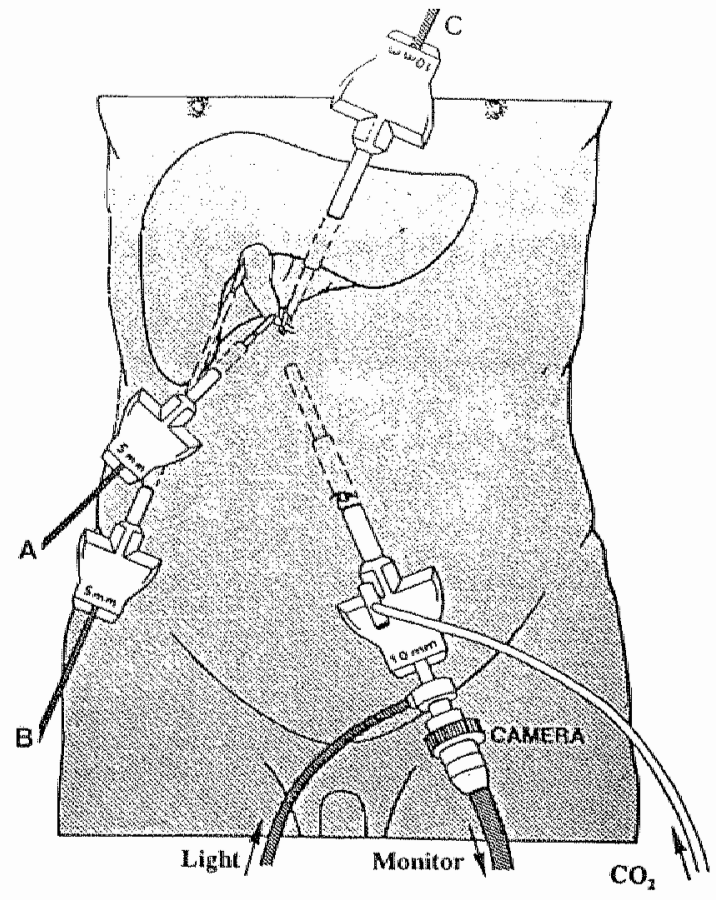

Fig.4. Positioning of trocars and instruments 


\section{Dussection of the galdbladder infindibulum}

A reducer is put in the proximal 10 mm trocar with an endoscopic dissecting instrument in place (fig.4, dissector C). Through both $5 \mathrm{~mm}$ trocars atraumatic grasping forceps are placed. The forceps in the most caudal $5 \mathrm{~mm}$ trocar is used to grasp the galbladder just beneath the top of the fundus and to apply cephalic traction towards the right diaphragm whereby the galbladder infundibulum becomes visible (fig.4, trocar B). With the forceps in the other $5 \mathrm{~mm}$ trocar (fig.4, trocar A), the infundibulum of the gallbladder is grasped and traction anterior laterally alternated with medially offers with this "flag" technique gaod view at the ventral and dorsal sides of Calot's triangle of the gallbladder (fig. Sa). The latter grasper and the dissecting instrument are both used by the surgeon. The task of the camera operator is limited to only give optimal visualisation of the operation area and it is therefore an attractive responsability for interns starting to involve them in laparoscopic surgery. The most lateral placed forceps is used by the assistent who also sometimes takes over the other forceps. If the view of the operating site is obscured, the patient should be placed in reverse Trendelenburg position and turned towards the left.

An endoscopic hook, a pair of scissors or a spatula with monopolar coagulation can be used for dissection depending on the surgeon's preference. Before starting dissection, adhesions surrounding the galbladder should be removed. The strategy of dissecting is to have a meticulous attention to the anatomy. Dissecting should start near the infundibulum towards the cystic duct and it is important to stay close to the wall of the galbladder during this phase so that bile ducts or hepatic vessels are not accidentally transsected. As soon as the junction of the cystic duct and galbladder is identified, it is necessary to identify the actual widening of the cystic duct into the neck. If this is not seen, it is possible that the cystic duct is very short and further dissecting is needed to be sure that the common bile duct is not transsected. It is vital to dissect also at the dorsal side of Calot's triangle to see the circumference of the cystic duct entrance to gabladder and common bile duct ("flag" technique). In this manmer an outflow of the cystic duct into the right hepatic duct can be identified. The cystic duct is further dissected retrograde so that it becomes apparent. Dissection of the cystic artery is performed in the same manner: It's entrance in the galbladder wall and the circumference of the artery should be fully freed and visible. If positive identification of cystic duct, cystic antery, common bile duct and their mutual relation is clear, the clip applicator is introduced through the proximall $10 \mathrm{~mm}$ 
trocar (fig. 5b). The cystic duct is clipped with 2 clips proximal and 1 or 2 distal of the transsection plane (fig.5b). A long cystic duct remnant is not a concerm. Attempts to shorten the cystic duct may result in an injury of the common bile duct. The cystic artery is double clipped at both sides (fig.5b). The cystic duct and artery are now transsected (fig.5c). If during dissection anatomy of the bile ducts is unclear or bile duct stones are suspected, a cholangiography should be made.

Fig.5a. Dissection of gallbladder infundibulum by "flag" technique.

A

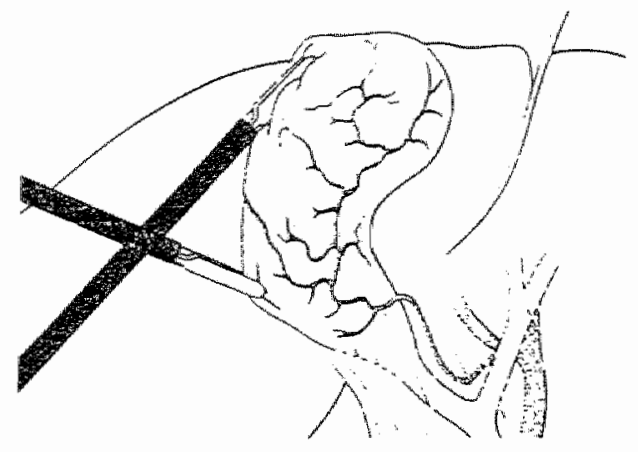

Fig.5b. Clipping of cystic duct and artery.

A

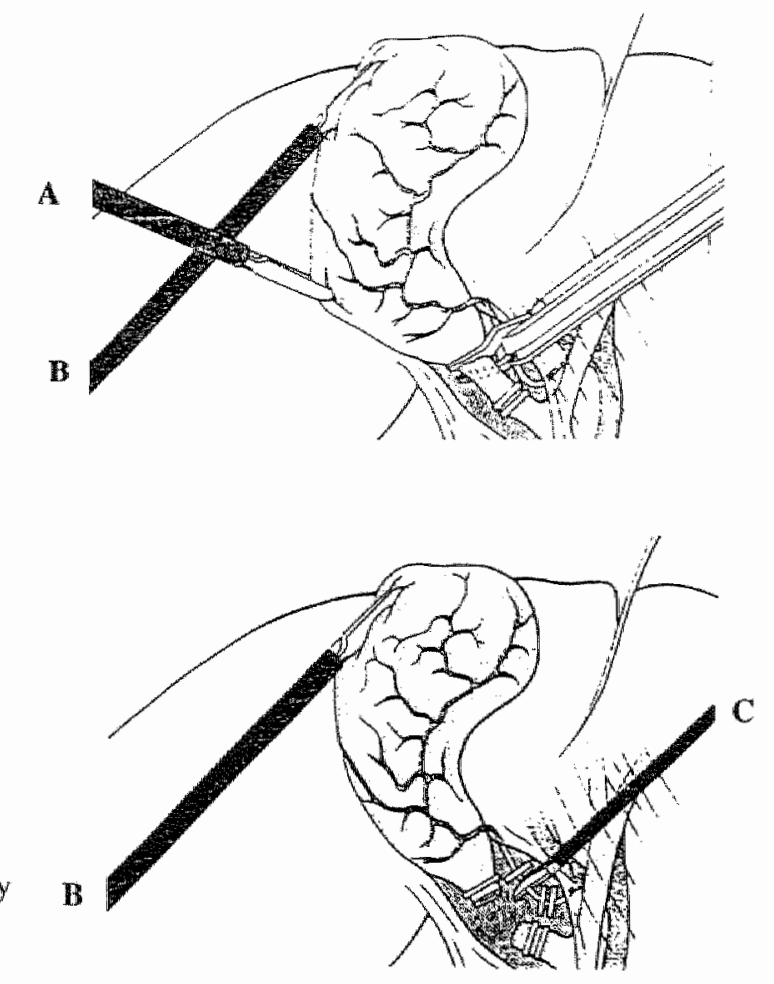

Fig.5c. Transection of cystic duct and artery with endoscopic scissors. 


\section{Cholangiography}

It is advocated, to use the cystic duct for a cholangiography because this facilitates the introduction and fixation of the catheter. Otherwise the common bile duct can be used. The cystic duct is clipped at the site of the gallbladder to prevent leakage of contrast solution into the gallbladder. The catheter should be filled up with contrast solution from a bag to prevent air bubbles. With the endoscopic scissors a small incision is made in the cystic duct. The catheter is introduced via the most proximal $5 \mathrm{~mm}$ trocar or the $10 \mathrm{~mm}$ subxyphoid trocar and inserted into the cystic duct with an aid of a grasper. If the common bille duct is used, an incision is made at the ventral side of the duct and the catheter is introduced. A cholangiography is now performed and evaluated. If stones are detected in the common bile duct, a flexible choledochoscope can be introduced wia the upper $5 \mathrm{~mm}$ trocar into the cystic or common bile duct incision. The stones can be removed with a basket guided through the choledochoscope. In case the common bile duct is opened, a T-tube should be placed for drainage.

\section{Resection of the gallbladder}

With the midclavicular forceps the gallbladder is grasped at its neck and lifted so that retrograde dissection of the gallbladder from the liver bed is possible with endoscopic scissors or other instruments (fig.6). By manipulating with both forceps, the transitional layer between gallbladder and liver bed is constantly visible which facilitates dissecting. After the gallbladder is resected, it is temporary positioned on top of the liver.

Fig.6. Resection of gallbladder.

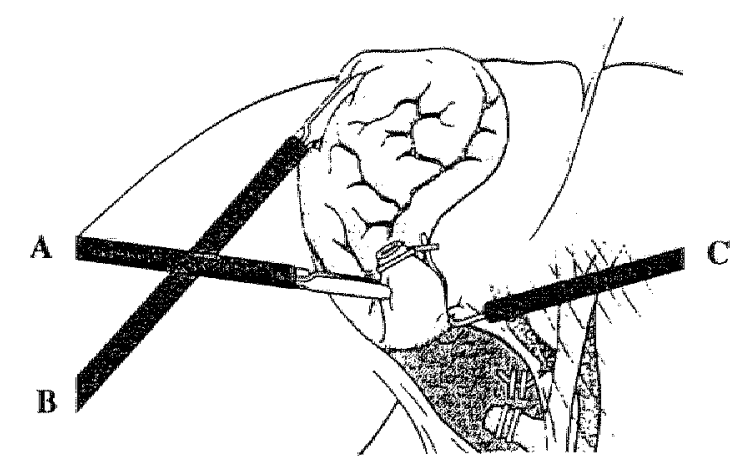

Remowal of the gallbladder from the abdomen

The gallbladder can be removed from the abdomen through the proximal or distal incision for the $10 \mathrm{~mm}$ trocars. If removed via the lower $10 \mathrm{~mm}$ trocar entrance, the laparoscope 
must be replaced in the upper $10 \mathrm{~mm}$ trocar and under visual control of the camera the gitllbladder is grasped at the cystic stump region and led to the intraabdominal opening of the umbilical $10 \mathrm{~mm}$ trocar (fig. $7 \mathrm{a}$ ). The $10 \mathrm{~mm}$ trocar, with the gallbladder held against its tip by the grasper, is pulled out of the abdomen (fig. $7 \mathrm{~b}$ ) and the gallbladder can now be grasped with a Kocher clamp and further pulled out (fig. $7 \mathrm{c}$ ). If the gallbladder with its content is to bulky to pass the fascia of the rectus, the fascia should be widened. It is also possible to crush stones in the gallbladder with a clamp through a small incision in a part of the gallbladder already brought out of the abdomen and in this way reducing its volume. Altematively, an electro shock wave lithotriptor is available to crush stones. If the gallbladder is removed via the upper $10 \mathrm{~mm}$ opening, the procedure is the same, except the laparoscope does not have to be repositioned to the other $10 \mathrm{~mm}$ trocar.
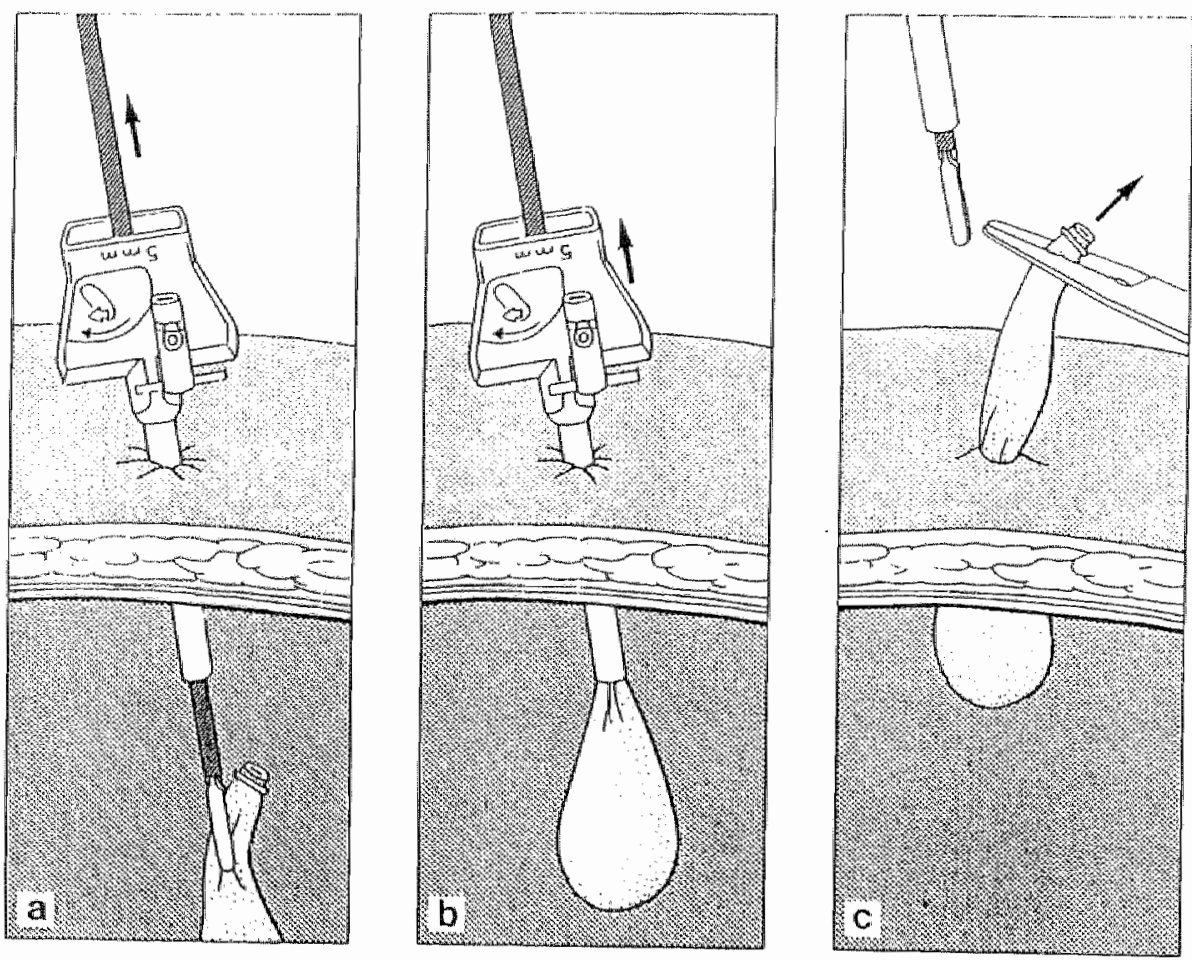

Fig.7. Removal of the gallbladder from the abdomen. 
Removal of the trocars

Directly after removal of the gallbladder, a finger has to be kept in the opening of the trocar site, to avoid loss of pneumoperitoneum. Before terminating the operation, the liver bed is checked for bleeding and if necessary it can be irrigated with saline. Removal of blood and/or bile will reduce postoperative discomfort in this area. Temporary drainage of the liver bed should be performed if loss of blood is more than $50-100 \mathrm{ml}$ or bile leakage occurred during the procedure. The drain can be inserted through the most caudal $5 \mathrm{~mm}$ trocar. Under visual control all the trocars are removed and the apertures are checked for bleeding. The laparoscope with its trocar is pulled out as lest instrument and now the carbon dioxide is allowed to escape.

The fascia at the umbilical site is closed and all skin incisions are closed with (intracutaneous) skin sutures. Wound dressing is applied.

\section{Postoperative care after laparoscopic cholecystectomy}

The urine catheter is removed at the OR. After reconvalescence at the recovery room, the naso-gastric tube can be removed. A few hours later the patient may start with liquids. The next morning the liver bed drain, if inserted, can be removed. Concerning the diagnosis of bile duct injury, the early symptoms are less specific than commonly suspected and are abdominal pain, nausea, vomiting, anorexia or ileus. Any patient who fails to recover within 24-48 hours after the laparoscopic procedure is suspicious for a bile duct injury and should be prolonged clinically observed.

Normally, the patient is discharged 24 hours after the laparoscopic cholecystectomy with an appointment in 7-10 days at the outpatients" clinic for removal of the stitches and to check the history of the past postoperative period at home. 

CHAPTER 4

Laparoscopic cholecystectomy in The Netherlands

Go P.M.N.Y.H., Schol F.P.G., Gouma D.J.

Br.J.Surg. 1993, 80: 1180-1183. 



\section{Summary}

Laparoscopic cholecystectomy was introduced in The Netherlands in the spring of 1990. The aim of the present study was to ewaluate the results of laparoscopic cholecysteciony in The Netherlands over the furst 2 years in order to obtain some insight into the safety and efficacy of laparoscopic cholecystectomy in general surgical practice.

A written survey was sent to the 138 surgical institutions in the Netherlands, inquiring about conversion rate, complications (with emphasis on mortality and common bille duct lesions) average operation time and hospital stay.

The surgeons' opinion was asked on possible contraindications such as prior operations, common bile duct stones and cholecystitis, as well as their estimation of the percentage of patients in their practice who were eligible for laparoscopic cholecystectomy. Data on 6076 laparoscopic cholecystectomies were obtained. The compliance of the survey was $100 \%$. Conversion to open cholecystectomy was necessary in $413(6.8 \%)$ patients mostly because of adhesions, cholecystitis, hemorthage and unclear anatomy. Postoperative complications were reported in $260(4.3 \%)$ patients. The mortality was $7(0.12 \%)$. There were $52(0.86 \%)$ common bile duct injuries, of which 20 were recognized during laparoscopy. The average operation time for the last 10 patients per institute was 70 (30-180) minutes and the average hospital stay was 4.5 (2-8) days. Prior lower abdominal operations were not considered to be a contraindication by $96 \%$ of the surgeons, whereas prior upper abdominal procedures were regarded as a contrandication by $66 \%$. After successful ERCP clearance of the bile duct only $12 \%$ would perform an "open" procedure. Moderate cholecystitis was not considered a contraindication by $71 \%$ of the surgeons, but severe cholecystitis was a reason for "open" cholecystectomy for $83 \%$. In most surgical practices 70-80\% of the patients were considered to be eligible for laparoscopic chollecystectomy.

In conclusion: laparoscopic cholecystectomy has gained rapid acceptance in The Netherlands. Although the numbers of common bile duct lesions are high, the results of this general survey are comparable with results from highly specialized centers and match the overall results of conventional cholecystectomy.

\section{Introduction}

In the spring of 1990, laparoscopic cholecystectomy was introduced in The Netherlands, a country with 15 million inhabitants with an annual average of 14000 cholecystectomies'. 
The technique was adopted from Belgian, French and American colleagues. In the autumn of 1990 several practical courses on a swine model were started, which accelerated the diffusion of the technique throughout the country. In addition to these courses, surgeons learned from experienced colleagues or visited facilities with expertise on laparoscopic cholecystectomy. Neither credentials were isswed, nor was it officially required.

Initial repons on the reduction of operative morbidity in laparoscopic cholecystectomy as compared to conventional cholecystectomy, and the patient demand provoked by the media, stimulated a rapid diffusion among Dutch surgeons. Most of the results reported in the literature are selected serites from centers with extensive personal experience ${ }^{2-4}$. Limited data are avalable on the results of laparoscopic cholecystectomy in general surgical practice $e^{s_{i} /}$, Results for the non-selected general patient population, previously treated by conventional cholecystectomy, should be collected to prove the safety and efficacy of laperoscopic cholecystectomy for the general popullation. Hence an attempt was made to review the results of laparoscopic cholecystectomy throughout The Netherlands over a period of two years, i.e. since its introduction.

\section{Patients and methods}

A written survey on surgical data concerning the results of laparoscopic cholecystectomy was sent to all 138 surgical institutions in The Netherlands. These institutions include 8 university centers, 28 teaching hospitals and 102 community hospitals. The period covered by the survey extended from the first laparoscopic cholecystectomy ever performed in The Netherlands, in February 1990, until the stan of the survey, in April 1992. Questions concemed the total number of laparoscopic cholecystectomies performed during that period, as well as the numbers of conversions to the open procedure and the indications for this policy. Other questions related to postoperative complications, with the emphasis on common bile duct lesions and mortality, as well as the average operation time for the last 10 procedures (or fewer, if experience was limited) and the average hospital stay including the day of admission and day of discharge, was taken. The surgeons" opinion was asked on possible contraindications for laparoscopic cholecystectomy, particularly prior operations, common bile duct stomes and clrolecystitis. Finally, the surgeons were asked to estimate the percentage of patients in their practice who would be eligible for laparoscopic cholecystectomy. 


\section{Results}

A questionnaire compliance of $100 \%$ was achieved. Completed forms were received from 103 institutions, while data from the other 35 institutions were collected by means of personal phone calls to the surgeons. In 134 of the 138 institutions 6076 laparoscopic cholecystectomies were performed during the period covered. On average of $45(1-230)$ procedures were performed per institution. Per institution the laparoscopic cholecystectony was in the hands of 1 or 2 surgeons from the practicing group. Conversion to open procedure was necessary in $413(6.8 \%$ ) patients (see table 1). The indications were matilly adhesions and cholecystitis. Initially, hemorthage, unclear anatomy, bile leakage from the gall bladder and certain technical problems were major reasons for laparotomy, but this changed as experience grew.

\begin{tabular}{|l|l|}
\hline Indications for conversion to open cholecystectomy & number \\
\hline Adhesions & 115 \\
\hline Hemorrhage & 80 \\
\hline Cholecystitis & 72 \\
\hline Unclear anatomy & 66 \\
\hline Common bile duct injury & 20 \\
\hline Bile leakage & 22 \\
\hline Technical problem & 15 \\
\hline Problems with instruments & 12 \\
\hline Carcinoma & 5 \\
\hline dlac artery lesion & 2 \\
\hline Caval vein lesion & 2 \\
\hline Bowel perforation & 1 \\
\hline Pneumothorax & 1 \\
\hline
\end{tabular}

Table 1. The reasons and the number of patients for conversion to "open" cholecystectomy" during laparoscopic cholecystectomy.

Postoperative complications were reported in $260(4.3 \%)$ patients (table 2). 


\begin{tabular}{|l|l|}
\hline Postoperative complications & number \\
\hline \hline Bile leakage & 49 \\
\hline Common bile duct lesions & 32 \\
\hline Retained stones & 6 \\
\hline Pancreatitis & 1 \\
\hline Incomplete gallbladder removal & 1 \\
\hline Wound infection & 79 \\
\hline Intra-abdominal abscess & 21 \\
\hline Hemorrhage & 46 \\
\hline Pneumonia/arelectases & 8 \\
\hline Prneumothorax & 1 \\
\hline Incisional hemia umbilicus site & 5 \\
\hline Incisional hernia epigastric site & 2 \\
\hline Colonic perforation & 2 \\
\hline Transient Ischemic Attack & 1 \\
\hline Congestive heart failure & 2 \\
\hline Cardiac ischaemia & 1 \\
\hline Pulmonary emboli & 2 \\
\hline Deep venous thrombosis & 1 \\
\hline
\end{tabular}
Table 2. The number and type of surgical complications in the postoperative course of the
laparoscopic cholecystectomy.

Bile leakage was observed as bile leakage from the wound drain or as fluid collection at postoperative ultrasonography, but this rarely resulted in laparotomy. The majority of the hemorrhage complications consisted of postoperative hemoglobin decrease, which did not necessitate surgical intervention. Common bile duct injuries were reported in $52(0.86 \%)$ patients. Twenty injuries were detected during the procedure and corrected immediately. Thirty two injuries were found postoperatively. The operative mortality was 7 patients $(0.12 \%)$. Three patients died following common bile duct repair after laparoscopic injury because of, respectively septicemia, massive gastrointestinal hemorrhage and pulmonary 
emboli. Two patients died because of myocardial infection, one from an incorrectly assessed cystic artery hemorrhage and one from a rapidly spreading Clostridium perfringens septicemia following a cystic duct leakage.

The average operation time was $70(30-180) \mathrm{min}$. In those centers where experience was less than 15 procedures the average operation time was $100(55-200) \mathrm{min}$. This time decreased to an average of 66 (40-90) min. after more than 15 procedures. The average hospital stay was 4.5 (2-8) days. The Dutch surgeons' opinions on contraindications for laparoscopic cholecystectomy are presented in table 3, showing a range from absolute to relative contraindications. Figure 1 shows the surgeons' rather divergent estimates of the percentage of their patients that would be eligible for laparoscopic cholecystectomy.

\begin{tabular}{|l|l|l|}
\hline Contra indications & Yes (\%) & No (\%) \\
\hline Prior lower abdominal procedures & 4 & 96 \\
\hline Prior upper abdominal procedures & 66 & 34 \\
\hline CBD stones in situ & 89 & 11 \\
\hline CBD stones clearance after successful ERCP & 12 & 88 \\
\hline Moderate cholecystitis & 29 & 71 \\
\hline Severe cholecystitis & 83 & 17 \\
\hline
\end{tabular}

Table 3. The surgeons' opinion on contraindications for laparoscopic cholecystectomy derived from the national survey.

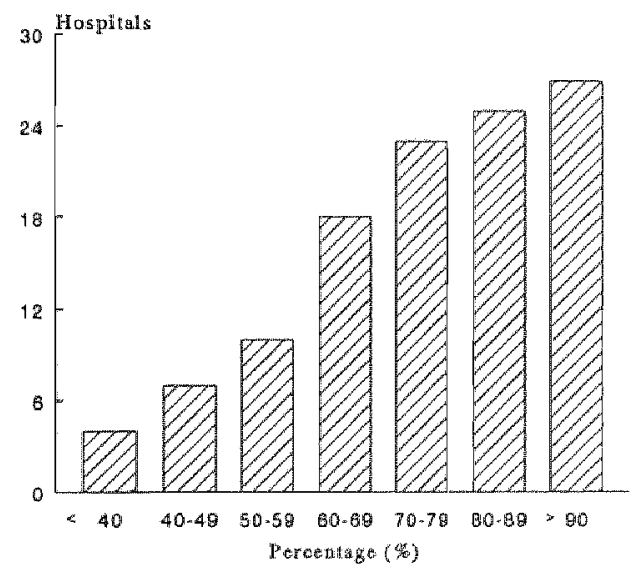

Fig.1. The opinion of each surgical group per hospital on the percentage of cholecystectomies that can be performed laparoscopically in their surgical practice. 


\section{Discussion}

In this survey a $100 \%$ compliance could be obtained because The Netherlands is a relatively small country with a coherent surgical group. After the introduction of laparoscopic cholecystectomy in The Netherlands, surgeons from more than half of the hospitals were taught at our center, which obviously facilitates communication. Fact is that laparoscopic surgery still is in its early stages, with an average experience of 45 cholecystectomies per hospital. In addition the great interest in these procedures, have contributed to an accurate data registration. Limitations with regard to asking detailed and difficult to retrieve information over a broad area have to be accepted to achieve high compliance and reliable data in this national survey.

Two years after its introduction almost all Dutch institutions now perform laparoscopic cholecystectomy, except for 1 cancer hospital and 3 community hospitals. Most of the surgical teams started laparoscopic surgery in the course of 1991. The experience per hospital varies widely and is also affected by the availability of the laparoscopic instruments. More than a third of the hospitals performed their procedures with instruments on loan from companies.

In view of the fairly limited experience, a conversion rate of $6.9 \%$ is acceptable. In the early stages, surgeons show a low threshold for conversion to the "open" procedure. As experience grows, adhesions, cholecystitis, minor hemorrhage, technical problems and gallbladder perforations lead to lower conversion rates.

The mortality rate was $0.12 \%$. In 5 of the 7 patients concerned, death was related to complications of laparoscopic cholecystectomy: in 3 to common bile duct injury, in 1 to cystic artery hemorrhage and in I to septicemia following bile leakage. McSherry and Glenn ${ }^{7}$ reported a $0.5 \%$ mortality in non-complicated cholecystectomies mainly caused by cardiovascular clisease. If laparoscopic cholecystectomy becomes a routine procedure, even lower surgical mortality figures can be expected than those reported in the present survey. Complications of laparoscopic cholecystectomy can be related to laparoscopy, to cholecystectomy or to surgical procedures in general. Complications related to laparoscopy consist mainly of vascular or bowel injury due to trocar insertion and of pneumothorax as a result of the pneumoperitoneum, which occur in $9 / 6067(0.15 \%)$. Despite the general use of trocats with a safety shield for the first trocar insention, injuries do still occur. Insufficient pneumoperitoneum, usually at reinsertion of the trocar, reduces the distance 
between the abdominal wall and intra-abdominal structures, leading to injury. In cases of pneumothorax a relatively high intra-abdominal pressure (15 mmHg or higher) was used, which should be avoided.

Complications related to cholecystectomy consist of hemorrhage, common bile duct injuries, bile leakage and retained stones. Severe hemorthage during operation can be salvaged by means of laparotomy. One patient died because of an incorrectly evaluated cystic artery hemorrhage in the immediate postoperative course. This argues for overnight monitoring of the patient after laparoscopic cholecystectomy. Common bile duct lesions are a major complication, detected in 20 patients during laparoscopy and in 32 patients in the postoperative course. The figure of $0.86 \%$ common bile duct injuries found in this study is higher than the $0.2-0.3 \%$ reported for conventional cholecystectomy". In the early stages approximately $1 \%$ common bile duct injuries were reported by several authors ${ }^{3 \%, 11}$. The fact that the present study includes the early experience of all centers in one country might explain the relatively high incidence of common bile duct injuries. A dectease with time may be expected. In 3 patients mortality was associated with common bile duct injuries, and these lesions were all detected in the postoperative course. If an injury is suspected during laparoscopy, an operative cholangiogram can indicate the injury and immediate treatment is then mandatory. Bile leakage was usually managed without reoperation and can be detected postoperatively by the combination of abdominal pain in the right upper quadrant and subhepatic fluid collection at ultrasonography or leakage at HIDA scanning. The low number of retained stones reported in the survey may be explained by the preoperative selection criteria, which included the absence of signs of the presence of common bille duct stones. Furthermore, the follow-up has been too short, and the incidence might be underestimated. Operative cholangiography is not performed routinely during laparoscopic cholecystectomy in The Netherlands.

Complications related to surgical procedures in general consist of wound infection, pulmonary and cardiac complications and thrombo-mbolic complications. The infection rate of $1,65 \%$ is lower than that in conventional cholecystectomy, and does not support the use of routine antibiotic prophylaxis. Although 2 patients died from myocardial infarction, the number of general complications found was low. 5 patients had incisional hernias at the umbilical site and 2 at the epigastric site. Since the gallbladder is usually extracted through the umbillical incision and is sometimes enlarged, separate fascia closure is 
recommended. The awerage operation time decreased from 100 min. for the first 15 procedures to approximately 1 hour, which indicates a leaming curve. The average hospital stay, including the day of admission and the day of discharge, was 4.5 days for laparoscopic cholecystectomy, which means a reduction in the awerage hospital stay for complicated and uncomplicated cholecystectomies: in The Netherlands, which was 13.5 days prior to introduction of laparoscopic cholecystectomy.

At the introduction of Japaroscopic cholecystectomy, prior laparotomies, common bile duct stones and cholecystitis were assumed to constitute (relative) contraindications. The present Dutch surgeon's opinion is more liberal. Prior lower abdominal incision is hardly felt to be a contraindication, but there is some reserve with regard to upper abdominal operations. With the back-up of experienced gastroenterologist to perform ERCPs, common bile duct stones are generally not felt to be a major contraindication for laparoscopic cholecystectomy. Still, most surgeons prefer prior clearance of the bille ducts before attempting laparoscopic cholecystectomy. Eligibility of patients for a laparoscopic approach to cholecystitis depends on the surgeon's experience. The surgeons" estimate that $70-90 \%$ of the patients with gallstone disease will benefit form the laparoscopic cholecystectorny in The Netherlands.

In conclusion, laparoscopic cholecystectomy is rapidly being implemented in The Netherlands. Although no credentialing system exists, the procedure is relatively safe in general practice. The number of conversions and serious complications such as severe trocar llesions and common bile duct injuries are expected to decrease as most of the surgical institutions have passed the lag phase of their learning curve. The reductions in surgical morbidity and hospital stay will benefit 70-90\% of the patients with gallstone disease in The Netherlands over the next years. 


\section{Acknowledgenent}

The authors are indebted to the next surgeons for providing their clinical data:

Dr. A.B. Bijnen - Alkmaar

P.J.H. Smits - Almelo

H.R. Korsten - Almere

A.J. den Outer Alphen a/d Rijn

Dr. G.H.M. Verberne - Amersfoort

F.A. Sjollema - Amstelveen,

L.T. de Wit - Amsterdam,

Dr. M.A. Cuesta Valentin - Amsterdam,

Dr. A.C.H. Boissevain - Amsterdam,

G.L. Mulder - Amsterdam,

Dr. R.M.J.M. Butzelaar - Amsterdam,

Dr. H.F.W. Hoitsma - Amsterdam,

Dr. J.A. Lawson - Amsterdam,

Dr. Th.A.A. van den Broek - Amsterdam,

Dr. E.J.Th. Rutgers - Amsterdam,

Dr. A. Schouten - Apeldoom,

J. de Vries - Assen,

T.I.F.M. Bloemen - Arnhem,

Dr. W.R. de Vries - Arnhem,

M.S. Verwey - Baarn/Soest,

E.J.R. Slingenberg - Bergen op Zoom,

Sj.H.M. Vrind - Bilthoven,

H.P.N.W. Hoedemaker - Blaricum,

G.A.M. van Gaal - Boxmeer,

Dr. J. Vroemen - Breda,

G.A.M. Kokke - Breda,

J. wan der Bijl - Brunssum,

Dr. C.J. van Steensell - Delft,

G.C. Kouwenhoven - Dellfzijl,

J.J.M. Jutte - Den Helder,
F.J.A.A. van Beek - Deume,

Dr. M. Eeftinck Schattenkerk - Deventer,

P. Heres - Dirksland,

Dr. F.M. van Lammeren -Doetinchem,

D.B. Wouters - Dokkum,

P.J. Mouthaan - Dordrecht,

G.F.A.M. van Beek - Dordrecht.

Dr. R.J. Oostenbroek - Dordrecht,

C.D. Hermsen - Drachten,

M.A. Melsom - Ede/Wageningen/Bennekom,

Dr. W.F.M. van Erp - Eindhoven,

Dr. J. Jakimowicz - Eindhoven,

A.S.N. Hirzalla - Emmeloord,

L.S. van der Zouwen - Emmen,

Dr. J.J.G.M. Gerritsen - Enschede,

Dr. C.R. van den Hoogenband - Geldrop,

J.A.C.M. Povel - Geleen,

Dr. C.M. Dijkhuis - Goes,

H.J.M. Kok - Gorinchem,

Dr. S. Franken - Gouda,

D.J. Swank - Gouda,

Dr. J.M. Heslinga - 's-Gravenhage,

Dr. M.B. Lagaaif - 's-Gravenhage,

Dr. B.C. de Vries -"s-Gravenhage,

P.V.M. Pahliplatz - 's-Gravenhage,

H.O. ten Cate Hoedemaker - Groningen,

Dr. A.J. Julius - Groningen,

H.E. Henneveld - Haarlem,

B. Lether-Haarlem, 
Dr. E.J. Boerma - Haarlem,

Dr. C.E Mater - Hardenburg,

R.B. Beck - Harderwijk,

Dr. W.B. Goudsward - Harlingen,

Dr. W.E. Tuinebreijer - Heemskerk,

J. Lens - Heerlen,

J.G. Bnyel - Heerenveen,

Dr. G.J.C.M. Niessen - Helmond,

B.A. van Driel - Hengelo,

J.H. Duppen - 's Hertogenbosch,

Dr. F.G.l. Willekens - 's-Hertogenbosch,

T.J.M.J. Schiphorst - "s-Hertogenbosch,

H.J.M. Dieben - Hilversum,

H.P. Dahler - Hoogeveen,

E. Scheijde-Hoom,

Dr. J.J. Petit - IJmuiden,

J. Ettema - Kampen,

Dr. P.A. Vegt - Kerkrade,

R. Leemans - Leeuwarden,

J.M.L.M. Horbach - Leiden,

Dr. J.A. Zonnevylle - Leiden,

H.J. Ellerbeck - Leiderdorp,

D. Hull" Varkamp - Leidschendam,

Dr. B.J. Reitsma - Lelystad,

P.M. Raams - Meppel,

Dr. A. Jansen - Nieuwegein,

Dt. J.H.C. Kuijpers - Nijmegen,

Dr. H.W.O. Deleu - Nijmegen,

J.G.F. van Kleef - Oostburg,

O.I. van West - Oosterhouty-

Ratmsdonkveer,

Dr. C.D. van Duyn $-\mathrm{Oss}$,
I.W.M. Bol - Purmerend,

P.J.H. Sikkenk - Roermond,

M. Borst - Roosendaal,

Dr. I.F. Lange - Rotterdam,

Dr. J.F. Hamming - Rotterdam,

Dr. R.U. Boelhouwer - Rotterdam,

Dr. M.K.M. Salu - Rotterdam,

H. Strijdhorst - Rotterdam,

H.W. Prillevitz - Rotterdam,

Dr. I.W. Merkelbach - Rotterdam,

Dr. Th. Wiggers - Rotterdam,

M. V.G. Kagie - Schiedam,

Dr. A.G.M. Hoofwijk - Sittard,

Dr. C. van Driel - Sneek,

A.l. van Beek - Spijkenisse,

E.R.M. Plantinga - Stadskanaal,

J.H. Viersma - Terneuzen,

K.H. Ong - Tie],

Dr. H.J.M. Oostvagel -

Tilburg, F. Jacobs - Tilburg,

Th.E. Fick - Utrecht,

L.S. de Vries - Utrecht,

Dr. P. Leguit - Utrecht,

J.M. Wakelkamp - Utrecht,

Dr. W.J.C. Geurts - Utrecht,

C.J. Broers - Veghel,

Dr. C.M.A. Bruyninckx - Veldhoven,

L.H.M. de Keujser - Velp,

Dr. I.F.M. Reinders - Venlo,

C.D.G.W. Verheij - Venray,

H.J. Rath - Vlaardingen,

J.A. Kriele - Vlissingen, 
I.H. Oei - Voorburg,

P.G. Beekman - Waalwijk,

J.A.L. Jansen - Weer,

R. Luyendijk - Winschoten,

A. Jonk - Winterswijk,

J.P. Vente - Woerden,

Dr. E.Pll. Steller - Zaandam,

M. Dommering - Zeist,
C. Sieswerda - Zevenaar,

R.A. Hellingman - Zierikzee,

P.J.J. van Rijn - Zoetermeer,

J.M.D. Schut - Zutphen,

Dr. W. van Rooyen - Zwolle,

Dr. P. Klementschitsch - Zwolle,

W.F. Blom - Zwijndrecht 


\section{Referencess}

1) Informatiecentrum voor de gezondheidszorg. In: Jaarboek Ziekenhuizen 1990. Utrecht, Amsterdam: $\mathrm{SIG}_{1}$ 1991: 117.

2) Cuschieri A, Dubois F, Mouiel J, Mouret $\mathbb{P}$, Becker $H$, Bress G, Trede M, Troidl $H$. The European Experience with laparoscopic cholecystectomy. Am J Surg 1991; 161: 385-387.

3) Myers $W^{*}$, Branum $G D$, Farouk $M$ et al. A prospective analysis of 1518 laparoscopic cholecystectomies.N Engl J Med 1991; 324: 1073-1078.

4) Holokan TV. Laparoscopic cholecystectomy. Lancet 1991; 338: 801-803.

5) Wilson P, Leese T, Morgan WP, Kelly JF, Brigg JK. Elective laparoscopic cholecystectomy for "all-comers". Lancet 1991; 338: 795-797.

6) Larson GM, Vitale GC, Casey $J$ et al. Multipractice analysis of laparoscopic cholecystectomy in 1983 patients. Am J Surg 1992; 163: 221-226.

7) McSherry CK, Glenn F. The incidence and causes of death following surgery for non malignant biliary tract disease. Ann Surg 1980; 191: 271-275.

8) Andersen-Sandberg A, Alinder $G_{*}$ Bengmark S. Accidental lesions of the common bile duct a cholecystectomy. Ann Surg 1985; 201:328-332.

9) Peters JH, Ellison C, Innes JT, Liss JL, Nichols KE, Lomano JM, Roby SR, Front ME, Carey LC. Safety and efficacy of laparoscopic cholecystectomy; A prospective anallysis of 100 initial patients. Ann Surg 1991; 213: 3-12.

10) Zucker KA, Bailey RW, Gadacz TR, Imbembo AL. Laparoscopic guidled cholecystectomy. Am J Surg 1991; 161: 36-44. 


\section{CHAPTER 5}

Risk factors for bile duct injuries in laparoscopic cholecystectomy: Analysis of 49 cases

Schol F.P.G., Go P.M.N.Y.H., Gouma D.J.

Br.J.Surg. 1994, 81: 17866-1788 



\section{Summary}

In this study $49(0.81 \%)$ bile duct injuries are evaluated, which occured in 6076 laparoscopic cholecystectomies in The Netherlands from spring 1990 until fall 1992. The aim of this study was to classify the detected bile duct injuries on severity, to identify possible risk factors that may contribute to the origin of bile duct injuries and to correlate these with the severity of the injuries. The bile duct injuries were classified based on operative findings in 4 classes ranging from minor injuries $(I, I$, , IIa) to extensive injuries with loss of bile duct tissue (IMb) or localisation in the liver hilus (IV). Eleven class 1, 6 class $\mathbb{I}, 10$ class IIIa, 18 class IIIb and 4 class IV bile duct injuries were defected. In 16 patients the bile duct injury was detected during the laparoscopic cholecystectomy and the procedure was converted to a laparotomy. In 14 of these 16 patients, the bile duct injury was minor (class II, II and IIh). In 20 of the 33 patients in which the discovery of the injury was delayed to a second or third operation, more severe type of injuries (class IITb and class IV) were observed. Delayed detection of a bile duct injury was associated with more severity $(p=0.002)$. Of 8 patients with histological proven acute cholecystitis at cholecystectomy, 7 suffered sewere class IIIb or IV injuries. Experience of the surgeon with laparoscopic cholecystectomies showed to be an important factor in the incidence of bile duct injuries.

In conclusion: Acute cholecystitis and limited laparoscopic experience of the surgeon are contributing factors in the etiology of bile duct injuries in laparoscopic cholecystectomy.

\section{Introduction}

In spring 1990 the laparoscopic cholecystectomy was introduced in The Netherlands. It is currently the accepted method for the treatment of symptomatic cholelithiasis. Despite the reduction of operation morbidity resulting in a reduced hospital stay and exrly activity resumption, some substantial complications related to the laparoscopic cholecystectomy are reported. A severe complication is a bile duct injury. The reported incidence of the bile duct injury at laparoscopic cholecystectomy in large surveys varies between $0-1 \%{ }^{1.7}$. The origin of the bile duct injury in the laparoscopic approach is still partly unclear. Several risk factors have been suggested such as severe adhesions at the operation site, cholecystitis and laparoscopic experience of the surgeon ${ }^{811}$. Understanding the etiology may also lead to indices to prevent bile duct injuries. 
The first results of a national survey with a $100 \%$ compliance report 52 bile duct injuries in 6076 laparoscopic cholecystectomies. The aim of this study is to classify the bile duct injuries on severity, to identify a number of possible risk factors and to correlate these factors to the severity of the injury.

\section{Patients and Methods}

In the study on the results of the laparoscopic cholecystectomy in the first 2 years 6076 cases were reported by all 138 surgical institutions in The Netherlands ${ }^{12}$. Fifty-two patients with a bile duct injury in conjunction with a laparoscopic cholecystectomy were collected from 35 hospitals in this survey. Three reported injuries, however, were cystic duct injuries leaving 49 bile duct injuries for this study and leading to an overall incidence ratio of $0.81 \%$. One of the authors visited the 35 hospitals and reviewed the medical chart of these patients and interviewed also most of the surgeons concerned. Although it is possible that some cases were not reported, the authors consider the number of injuries reflecting the actual situation. All "other cases" mentioned during the surgeon's interview were checked. They were found to be already included or the procedures were not performed during the investigated period.

Since no classification of laparoscopic bile duct injuries is available, a classification proposed by L.W. Way ${ }^{13}$ (fig.1) is used. A class I injury of the bile duct is a minor defect mostly due to an erroneous tangentional incision. A class $\Pi$ injury is clipping of the bile duct. A class III injury consists of a complete transection of the bile duct. This class is divided in subclass IIIa without tissue loss and subclass IIIb with loss of bile duct tissue. Class IV injuries are considered those with a defect in the right and/or left hepatic duct. Class I. II and IIIa injuries are considered to be less severe compared to class IIIb and IV, because the latter are accompanied with tissue loss or involvement of one of the hepatic ducts. The designation of a bile duct injury to a specific class was based on findings during operation noted in the operation report and, if applicable, on results of endoscopic cholangiograply. Demogratic data such as sex, age, length and weight were analysed. We determined if the laparoscopic approach was acute or elective. We looked upon prior upper abdominal surgery and if a surgeon or resident performed the laparoscopic procedure. The experience of the surgeon with laparoscopic cholecystectomy was correlated with the occurence of his bile duct injuries. The moment of detection of the 
injuries and reason for conversion of the laparoscopic approach to laparotomy were examined. Also operation time was taken in account. The severity of the bile duct injuries was correlated with the moment of detection of the injuries and with the results of the histological examination of the gallbladder, especially the presence of inflammation.

\section{Statistical Analysis}

To evaluate if experience of the surgeon with laparoscopic cholecystectomy influence the incidence of bile duct injuries, we distributed the injuries found over 6 groups of 20 laparoscopic cholecystectomies each: 1-20; 21-40;41-60;61-80;81-100; 101-120. An injury was assigned to a specific group depending on the number of laparoscopic cholecystectomies performed by the surgeon until the injury was made. In each group the probability for the occurence of a injury was calculated by dividing the number of injuries in each group by the number of surgeons which at least performed the corresponding number of laparoscopic cholecystectomies, e.g. in the group 41-60 laparoscopic cholecystectomies 10 injuries occured, divided by 26 surgeons and thus giving at probability of 0.38 . Thereafter a logarithmic curve-fit analysis was performed (statistical software SPSSPC). The correlations of severity of the bile duct injury with moment of detection and with histological proven inflammation were statistical evaluated using a Yates chi-square test; $\mathrm{p}<0.05$ was considered statistical significant.

\section{Results}

A bile duct injury after a laparoscopic cholecystectomy occured in 43 women $(87 \%)$ and 6 men $(13 \%)$. Their median age was 41 years (range $21-74$ years). The patient's median length was $167 \mathrm{~cm}$ (range $153-178 \mathrm{~cm}$ ) and median weight $67 \mathrm{~kg}$ (range $52-119 \mathrm{~kg}$ ). Forty-eight patients were operated electively and 1 patient acutely. None of the patients had prior upper abdominal surgery. Only 2 patients were operated upon by a residents. The classification of the 49 bile duct injuries detected in this study is given in figure 1.

An increase of experience of the surgeon with laparoscopic cholecystectomy was associated with a decreasing probability to make a bile duct injury. The best curve-fit was a logarithmic curve with a $\mathrm{R}^{2}=0.83$ (fig.2). A logarithm was to be expected because the incidence of bile duct injuries will never be nought. 


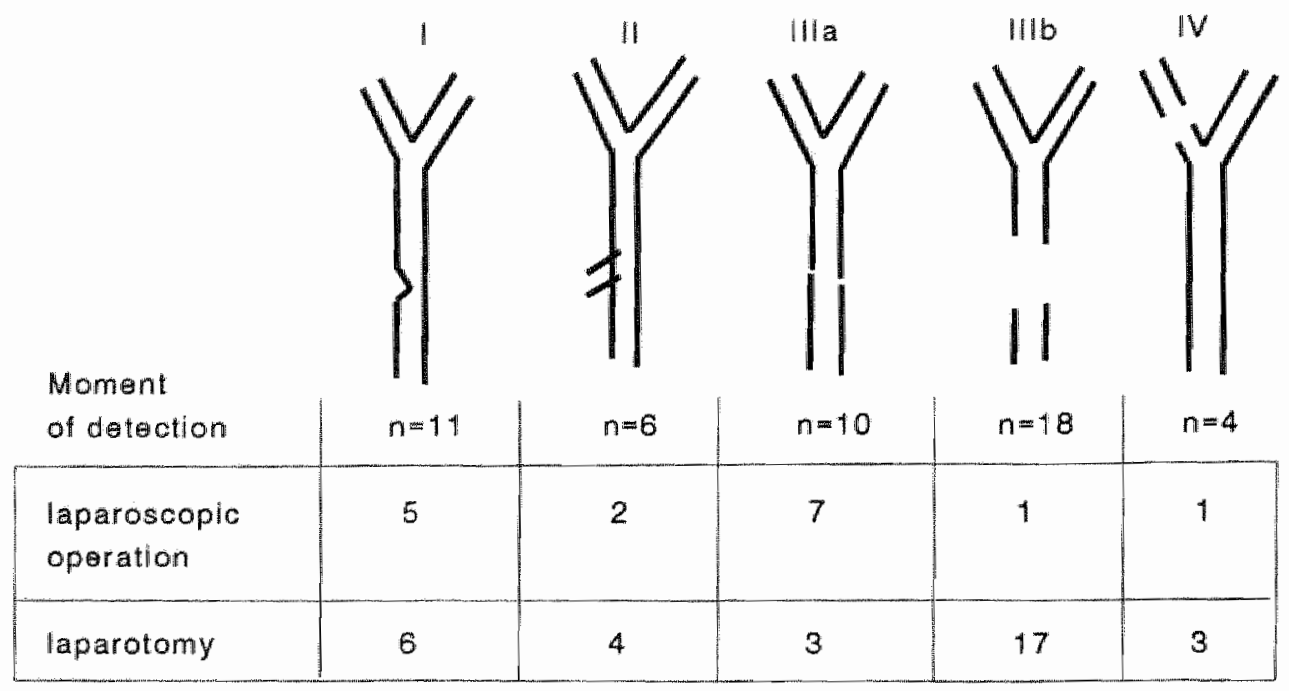

Fig.1. The classification of the bile duct injuries and the number of injuries in each class subdivided to the moment of identification i.e. during the laparoscopic operation or during successive laparotomies.

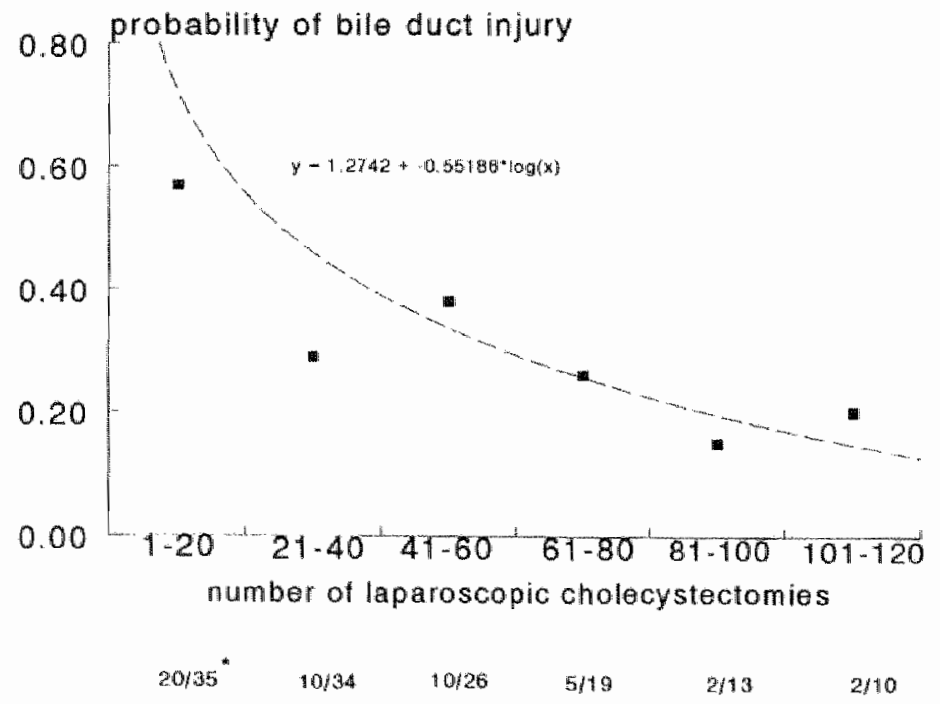

Fig.2. The influence of experience of the surgeon with laparoscopic cholecystectomies on the occurence of bile duct injuries. The probability of a bile duct injury is the number of injuries in a group divided by the number of surgeons in that group.

* $=$ number of bile duct injuries/number of surgeons 
In 16 of the 49 patients (32\%) the bile duct injury detas dected during laparoscopy leading to conversion to laparotomy and an immediate repair procedure (fig. 1). In these patients the bile duct injury was identified during the laparoscopic approach because of bile leakage in 12 cases and difficulties with proper identification of the surgical anatomy in 4 cases. After the laparoscopic cholecystectomy of the remaining 33 patients ( $68 \%$ ), the surgeon noted in the operation report of 21 patients difficulties with the anatomy in 11 cases, adhesions in 4 patients and miscellaneous problems in 6 patients. These 33 patients got clinical signs of bile leakage and/or bile obstruction and the suspicion of a bile duct injury was enhanced by liver function tests in all cases, ERCP in 17 patients, HIDA scanning in 7 patients, computer tomography in 5 patients and transhepatic cholangiography in 1 patient. All 33 patients got a laparotomy by which 32 bile duct injuries were discovered or confirmed (fig. 1). In I case a third operation was necessary to confirm the bile duct injury (fig.1). The mean operating time of the laparoscopic approach for the 33 patients with a delayed detection of the bile duct injury was 110 minutes as compared to the overall mean operating time of 70 minutes for the 6076 laparoscopic cholecystectomies.

In 14 of the 16 patients, who were immediately converted during the laparoscopic approach, the bile duct injury was less severe (class I, II and III.a) as compared to the patients in which the discovery of the injury was delayed (chi-square $=10.08, p=0.002$ ). The discovery or confirmation of 20 more severe type of injuries (class IIIb and class IV) was in most cases delayed to a second operation and in 1 case even to a third procedure (fig.1). From the 8 patients with histological proven acute cholecystitis 1 patient had a class IIIa injury, 6 a class IIIb injury and 1 patient a class IV injury. The bile duct injuries with histologically proven acute cholecystitis were more severe than those without acute cholecystitis ( $\mathrm{p}<0.05$, fig. 3 ).

\begin{tabular}{|c|c|c|c|}
\hline \multirow[t]{2}{*}{ \& } & & \multicolumn{2}{|c|}{ Cholecystitis } \\
\hline & & Yes & No \\
\hline Class & $1.11,111 a$ & 1 & 26 \\
\hline & $I H 1 b, 1 \mathrm{~W}$ & 7 & 45 \\
\hline
\end{tabular}

Fig.3. Statistical analysis of the severity of the common bile duct injuries and the presence of histological proven inflammation $\left(X^{2}=7.01, p=0.008\right)$. 


\section{Discussion}

Surveys to collect data from general practice can be performed relatively easy in The Netherlands thanks to the readiness of all involved surgeons with nation wide studies. An underestimation of the actual incidence of complications can still be expected in these studies. Therefore two independent different surveys were performed. A previous survey ${ }^{14}$ was focused on the number of repair procedures for bille duct injuries in 1991 after laparoscopic and open cholecystectomy. In this survey surgeons were asked to provide data on repair procedures including many referrals to centres. The incidence of these injuries was $1.09 \%$ during laparoscopic cholecystectomy and $0.51 \%$ during conventional cholecystectomy. In an other survey ${ }^{12}$ focused on the results of laparoscopic cholecystectomies published in this journal, an incidence of $0.81 \%$, i.e. 49 bile duct injuries during laparoscopic cholecystectomy, was identified in the period February 1990 uptill April 1992. The different incidence of bile duct injuries probably indicates an increased experience in the laparoscopic procedure and a different approach by asking complications rather than the number of repair procedures. There is a small overlap in patients, since both surveys overlap in time. The 49 cases identified in the latter survey ${ }^{12}$ form the basis of this analysis. The data were not collected from a survey, but derived from patient charts supplemented by personal information of all involved surgeons.

Several risk factors were analysed to identify predisposing factors for bile duct injuries.

Because only few patients had possible risk factors such as acutely being operated, operated by a resident or prior upper abdominal surgery, these factors can not be analysed as a risk factor in this study.

There is no clear classification of bile duct injuries in literature available. Only referral to anatomical variations of bile ducts as found at laparotomic cholecystectomy ${ }^{15}$. It is less suitable for laparoscopic use, because laparoscopic caused bile duct injuries have a specific laparoscopic related etjology as compared to laparotomic bille duct injuries. The bile duct injuries in this study were classified according to etiology and severity as proposed by L.W. Way ${ }^{13}$. Class $1, \mathrm{II}$ and Illa are considered less severe compared to class IIIb and IV injuries because the latter have tissue loss or involvement of a hepatic duct. Reconstruction of a class IIIb or IV injury is expected to be more cumbersome and the clinical course can be more complicated than with class I, II and MIa injuries. The advantage of this classification of bile duct injuries is its universality, so that it is possible 
in future studies to compare the the etiology and treament of the different classes of bile duct injuries. The curverfit analysis performed to evaluate the impact of experience with laparoscopic cholecystectomy on the occurence of bile duct injuries, suggests, that with increasing experience of the surgeons with laparoscopic cholecystectomy, less bile duct injuries will occur. Surgical experience in the laparoscopic cholecystectomy and the implementation of this procedure in surgical training programs are expected to decrease the incidence of bile duct injuries further to a level comparable to the conventional cholecystectomy as has been suggested earlier". The surgeons seem to have had more difficulties to perform the laparoscopic cholecystectomy than normal in the 33 patients, in whom the bile duct injury was detected or confirmed in a second or even third procedure by laparotomy. The laparoscopic procedure in these patients lasts longer than nomal: 110 minutes versus 70 minutes and in $2 / 3$ of the cases the surgeons recall problems during the procedure in the operation report, especially with the proper identification of the surgical anatomy. In The Netherlands operative cholangiography is not performed routinely. The value of operative cholangiography to prevent bile duct injuries has never been proven and is still under discussion. However, in the case of unclear anatomy or suspicion of a bile duct injury an operative cholangiography can be very helpful as a roadmap to prevent or to diagnose a bile duct injury. In addition, a low treshold for conversion to laparotomy should be maintained in difficult cases. This may limit more extensive damage. Less severe injuries class $\mathbb{I}$, II and IIla were detected significantly more frequent during the laparoscopic approach than in patients with delayed detection. Difficulties in recognition of the anatomy might amiss a complication and even lead to more severe injuries as was found in the patients with a delayed diagnosis of their bile duct injury, that were mosilly class IIIb and IV.

From this study acute cholecystitis can not be proven as a risk factor; becaluse the incidence of acute cholecystitis in the patients without bile duct injuries is unknown. However, if a bile duct injury occures, this injury tends to be more severe. In cases with inflammation, anatomy might be more difficult to identify and therefore lead to more extensive injuries.

In conclusion: An acute cholecystitis and limited laparoscopic experience of the surgeon are contributing factors in the etiology of bile duct injuries in laparoscopic cholecystectomy. Proper identification of surgical anatomy during laparoscopy is 
obligatory. If a bile duct injury is suspected, the procedure should be converted to a laparotomy, when there is enough experience with biliary surgery. Otherwise the patients should be submitted to a specialized center. 
1) Myers WC, Branum GD, Farouk M et al. A prospective analysis of 1518 laparoscopic cholecystectomies. N Engl J Med. 1991; 324: 1073-1078.

2) Larson GM, Vitale GC, Casey J, Evans IS, Gilliam G, Heuser L, McGee G, Rao M, Scherm MJ, Voyles CR. Multipractice analysis of laparoscopic cholecystectomy in 1,983 patients. Am J Surg. 1992; 163:221-226.

3) Suc B, Fontes Dislaire I, Fourtanier G, Escat J. 3,606 cholecystectomies sous coelioscopie. Registre de la Societe Francaise de Chirurgie Digestive. Ann Chir. 1992; 46: 219-226.

4) Deziel DJ, Millikan KW, Economou SG, Doolas A, Ko ST, Airan MC. Complications of laparoscopic cholecystectomy: a national survey of 4,292 hospitals and an analysis of 77,604 cases. Am J Surg. 1993; 165: 9-14.

5) Krämling HJ, Lange $\mathrm{V}$, Heberer $\mathrm{G}$. Aktueller stand der Gallensteinchirurgie in Deutschland. Chirurg 1993; 64: 295-302.

6) Schlumpf R, Klotz HP, Wehrli H, Herzog U. Laparoskopische Cholecystectomie in der Schweiz. Chirurg 1993; 64: 307-313.

7) Wagand W, Woisetschläger R, Gitter T. Laparoskopische Cholecystectomie in Österreich. Chirurg 1993; 64: 303-306.

8) Clavien PA, Sanabria JR, Mentha G, Borst F, Buhler L, Roche B, Cywes R, Tibshirani R, Rohner A, Strasberg SM. Recent results of elective open cholecystectomy in a North American and a European center. Comparison of complications and risk factors. Ann Surg. 1992; 216:618-626.

9) Caputo L, Aitken DR, Mackett MC, Robles AE. latrogenic bile duct injuries. The real incidence and contributing factors --implications for laparoscopic cholecystectomy. Am Surg. 1992; 58: 766-771.

1.0) Frazee RC, Roberts JW, Symmonds R, Styder SK, Hendricks J, Smith R, Custer MD. What are the contraindications for laparoscopic cholecystectomy? Am J Surg. 1992; 164: 491-494.

11) Unger SW, Scott JS, Unger HM, Edelman DS. Laparoscopic approach to gallstones in the morbidly obese patient. Surg Endose. 1991; 5: $116-117$.

12) Go PMNYH, Schol FPG, Gouma DJ. Laparoscopic cholecystectomy in The 
Netherllands. Br I Surg. 1993; 80: 1180-1183.

13) Way LW. Personal communication. SAGES-meeting, Washington DC, 1992

14) Gouma DJ, Go PMNYH. Bile duct injury during laparoscopic and conventional cholecystectomy. I Am Coll Surg. 1994; 178: 229-233.

15) Blumgart $\mathrm{LH}$. Benign biliary strictures. In: Blumgart $\mathrm{LH}$, ed. Surgery of the liver and biliary tract. Voll.1. Edinburgh: Churchill Livingstone, 1988: 721-752. 


\section{CHAPTER 6}

The outcome of 49 repairs of bile duct injuries after laparoscopic cholecystectomy

Schol F.P.G., Go P.M.N.Y.H., Gouma D.J.

World J.Surg., in press. 



\section{Abstract}

The way of treatment of bile duct injuries after laparoscopic cholecystectomy is still under discussion. The aim of this study was to evaluate the results of end-tomend or biliodigestive anastomosis for different types of bile duct injuries. Patient charts of 49 $(0.81 \%)$ classified bile duct injuries from a national survey of 6076 laparoscopic cholecystectomies in The Netherlands were analized. The median follow up after repair was 183 (range 14-570) days. Statistical anallysis showed that an end-to-end anastomosis was preferred by the surgeons for less severe bile duct injuries and a biliodigestive repair for more sewere injuries. Three patients died due to a delayed detected bile duct injury. Twelve bile duct strictures occured after repair leading to a stricture rate of $25 \%$. The period of time elapsed between repair and occurrence of a stricture was 134 (range 13270) days. Type of repair and severity of the bile duct injury did not determine the outcome of the repair. Histological proven cholecystitis was predisposing for a stricture at the repair site.

Conclusion: Treatment of bile duct injuries is associated with a high stricture rate at the repair site of the anastomosis. End-to-end anastomosis is mostly succesful in the less severe injury, that was detected during the laparoscopic cholecystectomy. In all other cases this repair can at least be considered as a temporarely internal drainage procedure. The biliodigestive anastomosis can best be considered as a delayed repair after a drainage procedure has resolved the local inflammatory status.

\section{Introduction}

After its introduction a few years ago, the complications of the laparoscopic cholecystectomy are becoming apparent ${ }^{1-5}$. The main problem of the laparoscopic cholecystectomy is the bile duct injury detected either immediately at the laparoscopic approach or during follow up. The treatment of bile duct injuries has several options. They include stenting, end-to-end anastomosis with or without T-tube drainage, Roux-Ycholedocho- or hepaticojejunostomy, choledochoduodenostomy and hepatogastrostomy ${ }^{60.11}$. The different types of repair for the bile duct injury are prone to complications such as bile leakage, cholangitis, biliary cirrhosis and recurrent strictures. Bile duct strictures can occur at any time after repair and may disable the patient.

From a national survey on 6076 laparoscopic cholecystectomies 49 bile duct injuries were 
identified $\mathrm{d}^{12}$ and classified to severity ${ }^{13}$. The aim of this study was to evaluate which repair procedure was applied for each type of bile duct injury in this nationall survey and to examine the outcome of the different treatments.

\section{Methods}

From spring 1990 until april 1992 a national survey revealed 49 bile duct injuries after laparoscopic cholecystectomy in The Netherlands ${ }^{12,13}$. The 49 injuries occured in 35 different hospitals and each institution was visited by one of the authors (FPGS) to analyze the clinical and outpatient charts for each patient individually. The 49 bile duct injuries were classified to severity. Class I(tangentional lesion), II(clip injury) and IIla(bile duct transection without tissue loss) injuries are considered to be less severe compared to class IIIb(bile duct transection with tissue loss) and IV(injuries of one of the hepatic ducts). In addition, it was registered whether the bile duct injury was detected and/or confirmed during the primary laparoscopic operation or later on at second procedure by laparotomy. The repairs were classified into end-to-end anastomosis of the bile duct with or without T-tube drainage and biliodigestive anastomosis. The severity of the bile duct injuries was correlated with the type of repair. The results, early and late complications during follow up were evaluated. Early complications consisted of bile leakage at the anastomotic site, haemorrhage, woundinfection, intraabdominal infection and death. Late complications were strictures at the repair site, which became apparent by jaundice, cholangitis or increased liver function tests. Patients were considered as non-complicated if they were symptom free and had nomal liver function tests during follow up. The type of repairs of the bile duct injuries that strictured and the original classification of these injuries were analysed. The time span between repair and the occurence of a stricture was examined. The outcome of the repair was correlated with the type of repair and with the severity of the bille duct injuries. The outcome was also correlated with the histological presence of inflammation of the galbladder during cholecystectomy. Finally, the treatment of patients with a stricture in their repaired bile duct injury was analysed.

\section{Statistical Analysis}

The correlation on severity of the bile duct injuries with sort of repair was statistical evaluated by using a Yates chi-square test (statistical software SPSSPC). The same test 
was used for the correlations on the outcome of repair with type of repair and with severity of the bile duct injury; p< 0.05 was considered statistical significant.

\section{Results}

The studied group contained 43 women $(87 \%)$ and 6 men $(13 \%)$ with a median age of 41 (range $21-74$ ) years. The median follow up after the repair operation was

183 (range 14-570) days. It was 156 (range 14-570) days for patients without strictures and 267 (range 30-425) days for patients with a stricture after repair. In 16 patients the bile duct injury was detected immediately during the laparoscopic cholecystectomy and in 33 patients the injury was delayed detected. The type of repair after detection of the bile duct injury, ordered to classification, is given in table 1. The surgeons had a preference to repair less severe bile duct injuries (class I,II,IIIa) with an end-to-end anastomosis with or without $\mathrm{T}$-tube drainage and more severe injuries (class $[\mathrm{II}, \mathrm{IV})$ with a biliodigestive anastomosis $(p<0.05)$. All 16 patients with a bile duct injury detected at the latparoscopic approach and 29 patients with delayed detected injuries received an immediate repair procedure upon discovery or confirmation. Four patients with a delayed detected injury had. a temporary drainage before the repair: This was in 2 patients suturing one or both ends of the bile duct injury around the legs of a T-tube and in 2 other patients a transcutaneous drainage of a subhepatic fluid collection. Two of these patients received a biliodigestive anastomosis respectively 200 and 210 days thereafter. One patient was planned for an anastomosis and 1 was only treated with transcutaneous drainage.

\begin{tabular}{|l|c|c|c|c|c|c|}
\hline & \multicolumn{5}{|c|}{ Classification } \\
\cline { 2 - 7 } & I & II & IIIa & IIIb & IV & Tota1 \\
\hline Transcutaneous drainage & - & 1 & - & - & - & 1 \\
\hline $\begin{array}{l}\text { End-to-End anastomosis } \\
+/-\quad \text { T-tube drainage }\end{array}$ & 11 & 4 & 9 & 2 & 2 & 28 \\
\hline $\begin{array}{l}\text { Biliodigestive } \\
\text { anastomosis }\end{array}$ & - & 1 & 1 & 15 & 2 & 19 \\
\hline $\begin{array}{l}\text { Planned for bilio- } \\
\text { digestive anastomosis }\end{array}$ & - & - & - & 1 & - & 1 \\
\hline
\end{tabular}

Table 1. Type of repair after detection of the bile duct injury ordered for each class of injury. 
The early complications after repair of the bile duct injuries are summarized in table 2. Three patients reated with a biliodigestive anastomosis after a delayed detected class $\mathbf{n}$, IIb and IV injury died respectively from 1. massive pulmonary emboli, 2. irreversibel gastric hamonthage and 3. sepsis with respiratory distress syndrome due to necrosis of the anastomosis. There was no significant difference in the occurence of early complications after end-to-end repair or biliodigestiwe anastomosis $(p=0.94)$ and whether the injury was detected and confirmed at the furst procedure or during following procedures $(p=0.47)$. Two patients had a reoperation to control an intrabdominal haemorthage. Two patients with bile leakage after a successful end-to-end and 2 patients after a biliodigestive anastomosis had a reoperation to repair this by additional sutures. The other patients with early complications were managed conservatively.

\begin{tabular}{|c|c|c|c|c|c|c|}
\hline 16 Patientes & Hone: & Wound ln $\mathrm{fection}$ & Pancreatitus & $\begin{array}{l}\text { Bile leakage } \\
\text { anastcmos is }\end{array}$ & Haemorrhage & Death \\
\hline $\begin{array}{l}\text { End-to-End anastomos is } \\
+/-T-t u b \text { dra inage }\end{array}$ & 9 & 2 & 11 & 2 & - & - \\
\hline $\begin{array}{l}\text { Hi i iodigers ive } \\
\text { anastomosig }\end{array}$ & 3 & - & - & - & - & - \\
\hline 33 patients (1 planned & or rep & & & & & \\
\hline Transcutaneous drainage & a. & - & - & - & - & - \\
\hline 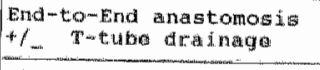 & 10 & 1 & - & 2 & 2 & - \\
\hline $\begin{array}{l}\text { Wil lod iquas tiva } \\
\text { andas tomos d, }\end{array}$ & 10 & sev. & - & 3 & - & 3 \\
\hline
\end{tabular}

Table 2. Early complications after the repair for the two groups treated at detection of the injury during laptroscopic approach or successive laparotomy.

The 12 strictures which occured as a late complication after the repair are described with their original chass of bille duct injury in table 3. The occurence of jaundice in 7 patients, relapses of cholangitis in 3 patients, peritonitis in $\|$ patient and increased liver function tests in an other patient raised the suspicion of a stricture. The median time span between repair and stricture was 134 (range 13-370) days. The type of repair, end-to-end versus 
biliodigestive anastomosis, did not determine the outcome of the repair $(\mathrm{p}=0.91)$. The severity of the bile duct injury, class I, II, IIIa versus class IIIb and IV, had no influence on the outcome of the repair $(\mathrm{p}=0.67)$. Eight patients had a histologically proven acute cholecystitis at cholecystectomy. Of these patients, 1 with a class II and 3 with a class IID injury developed a stricture after repair. Strictures developed more often in patients operated for acute cholecystitis than if this was abcent during cholecystectomy ( $p<0.05$ ).

Three of the 12 patients with a stricture in their repaired anastomosis were reoperated and got a biliodigestive anastomosis of which 1 restrictured within 30 days. This patient received a new biliodigestive anastomosis and became symptom free. Four patients were stented and 2 patients were treated expectatively. Three patients were planned for a new biliodigestive anastomosis. The median follow up of these 12 patients was 78 (range 0 158) days. Ten patients were still under medical superwision on outpatient basis at the onsite data registration in the involved hospitals.

\begin{tabular}{|c|c|c|c|c|c|c|c|}
\hline $\begin{array}{l}49 \text { patients } \\
\text { (1 planned for repair) }\end{array}$ & Mone & $\begin{array}{l}\text { Stricture of } \\
\text { anastomosis }\end{array}$ & $\begin{array}{l}\text { class of } \\
\text { injury }\end{array}$ & $\begin{array}{l}\text { Mam number } \\
\text { of days after } \\
\text { repair }\end{array}$ & Reoperation & Stenting & $\begin{array}{l}\text { Exped } \\
\text { tative }\end{array}$ \\
\hline $\begin{array}{l}\text { End-to-End amaistomogis } \\
\text { H- T-tube dratinage }\end{array}$ & 21 & 7 & $\begin{array}{ll}2 x & I \\
4 x & \operatorname{IITa} \\
1 \times & \text { IXIb }\end{array}$ & 13.3 & 2 & 4 & 1 \\
\hline $\begin{array}{l}\text { Diliodigestive } \\
\text { anastomosis }\end{array}$ & 14 & 5 & $5 \times 11 \mathrm{Ib}$ & $13 i 8$ & $4 *$ & - & 1 \\
\hline Transcutameous dxaltrage & 1 & - & - & - & $=$ & - & - \\
\hline
\end{tabular}

Table 3. Distribution and therapy of strictures originating after repair of the bile duct injuries.

\section{Discussion}

The survey showed an incidence rate of $0.81 \%$ for the occurrence of bile duct injuries at laparoscopic cholecystectomy in the early phase after the introduction of this operation in The Netherlands ${ }^{13}$. The treatment of bile duct injuries is still a major concern and is accompanied with a high long-term morbidity. This study reports a $25 \%$ stricture rate after different repair procedures of various types of bile duct injuries during a relative short 
follow up. This rate may be high compared to other series, but it includes a non-selected group with different types of bile duct injuries. Most of them were not treated in a specific referral center ${ }^{1,3,4}$. Many patients did not have an elective repair procedure in relatively optimal circumstances, but had an emergency procedure because of serious symptoms caused by the injury. Although in this study the strictures all occurred within a year after repair, more strictures might appear in this group in the near future. A long-term follow up therefore is advocated for these patients ${ }^{11,15}$.

In this series the less severe injuries class I, II and IIIa were mostly detected during the primary laparoscopic approach and were repaired with an end-to-nd anastomosis. The more severe class IIIb and IV injuries were usually repaired by a biliodigestive anastomosis. Current literature ${ }^{16,17,18}$ reports a higher rate of biliodigestive anastomoses for the repair of laparoscopic bile duct injuries as compared to this series because most repaits are performed as secondary procedure. In our series the postoperative complications are not significantly different for both types of repairs. However, the three patients, who died, had a delayed repair with a biliodigestive anastomosis. Therefore, we should realize that both groups are not comparable.

There was no difference in the number of strictures after both types of repairs which is probably due to the limited number of patients in each group. A significantly higher number of strictures were mainly found in patients with a cholecystitis during cholecystectomy. Acute cholecystitis should therefore be seen as a contributing factor leading to stricture formation.

The different options of treatment are mainly dependent on the moment of detection of these injuries. If a bile duct injury is suspected during the laparoscopic operation the lesion can be confirmed at laparotomy. This implies that any type of treatment has to be performed instantly. The less severe type injuries, class I, II, IIIa, can be treated with a simple suture repair or end-to-end anastomosis with a fair outcome. Impairment of bile duct vasculature, especially after transection (class IIla) may increase the change on anastomotic stricture after an end-to-end anastomosis ${ }^{19}$. However, in these circumstances stenting or balloon dilatation can be attempted as a minimal invasive, non-operative treatment. Nevertheless, if a severe stricture may develops, a biliodigestive anastomosis can be performed electively on the dilatated proximal duct. The immediate repair of more severe injuries class IIIb and IV often necessitates a (double) biliodigestive anastomosis 
because of tissue loss. This is a difficult procedure to perform on the usually non-dilated hepatic duct. A high incidence of stricture formation can be expected as confirmed in this study. When facing a severe bile duct injury after conversion to laparotomy the option of a biliodigestive anastomosis still remains the only possible treatment. This should be done by surgeons with experience in hepatobiliary surgery, otherwise immediate referral to at specialized center is highly recommended.

If detection or confirmation of a bile duct injury is delayed to a second procedure an inflammatory status may already have occurred. In the less severe injuries an end-to-end repair can be considered. However, this should be considered more as temporarily internal drainage than a definite treatment because an even higher incidence of anastomotic strictures can be expected in the patients with a local inflammatory status. A biliodigestive anastomosis will often be necessary in a later stage. In severe class IIIb and IV lesions percutaneous drainage or intemal tube drainage is preferred. When the inflammatory status has resolved an elective biliodligestive anastomosis will be more successful. An immediate treatment with biliodigestive anastomosis is probably associated with a higher incidence of complications and even mortality as found in this study and therefore not recommended as a routine treatment in these circumstances.

In this survey many delayed injuries were detected during an explorative laparotomy, because of serious symptoms. It should be stressed that diagnostic procedures such as ERCP, PTC, and transcutaneous drainage of fluid collections should preferably be performed before a laparotomy is considered ${ }^{16,20}$.

In conclusion: Treatment of bile duct injuries is associated with a high stricture rate at the repair site of the anastomosis. End-to-end anastomosis is mostly successful in the less severe injury, that was detected during the laparoscopic cholecystectomy. In all other cases this repair can at least be considered as a temporarily internat drainage procedure. The biliodigestive anastomosis can best be considered as a delayed repair after a drainage procedure has resolved the local inflammatory status. 


\section{References}

1) Deziel, D.J., Millikan, K.W., Economou, S.G., Doolas, A., Ko, S.T., Airan, M.C.: Complications of laparoscopic chrolecystectomy: a national survey of 4,292 hospitals and an analysis of 77,604 cases. Am. J. Surg. 165:9, 1993

2) Adams, D.B., Borowicz, M.R., Wootton, F.T., Cunningham, J.T.: Bile duct complications after laparoscopic cholecystectomy. Surg. Endosc. 7:79, 1993

3) Larson, G.M., Vitale, G.C., Casey, J., Evans, J.S., Gilliam, G., Heuser, L., McGee, G., Rao, M., Scherm, M.J., Voyles, C.R.T.I.: Multipractice analysis of laparoscopic cholecystectomy in 1,983 patients. Am. J. Surg. 163:221, 1992

4) Myers, W.C., Branum, G.D., Farouk, M.: A prospective analysis of 1518 laparoscopic cholecystectomies. N. Engl. J. Med. 324:1073, 1991

5) Wolfe, B.M., Gardiner, B.N., Leary, B.F., Frey, C.F.: Endoscopic cholecystectomy. An analysis of complications. Arch. Surg. 126:1192, 1991

6) Manoukian, A.V., Schmalz, M.J., Geenen, J.E., Hogan, W.J., Venu, R.P., Jolunson, G.K.: Endoscopic treatment of problems encountered after cholecystectomy. Gastrointest. Endosc. 39:9, 1993

7) Kozarek, R., Gannan, R., Baerg, R., Wagonfeld, J., Ball, T.: Bile leak after laparoscopic cholecystectomy. Diagnostic and therapeutic application of endoscopic retrograde cholangiopancreatography. Arch. Intern. Med. 152:1040, 1992

8) Blumgart, L.H., Kelley, C.J., Benjamin, I.S.: Benign bile duct stricture following cholecystectomy: Critical factors in management. Br. J. Surg. 71:836, 1984

9) Genest, J.F., Nanos, E., Grundfest-Broniatowski, S., Vogt, D., Hermann, R.: Benign biliary strictures: An analytic review (1970-1984). Surgery 99:409, 1986

10) Andren-Sandberg, A., Johansson, S., Bengmark, S.: Accidental lesions of the common bile duct at cholecystectomy. II. Results of treatment. Ann. Surg. 201: 452 , 1985

11) Pitt, H.A., Miyamato, T., Parapatis, S.K., Tompkins, R.K., Longmire, W.P.:

Factors influencing outcome in patients with postoperative biliary strictures. Am. J. Surg. 144:14, 1982

12) Go, P.M.N.Y.H., Schol, F.P.G., Gouma, D.J.: Laparoscopic cholecystectomy in The Netherlands. Br. J. Surg. 80:1180, 1993 
13) Schol, F.P.G., Go, P.M.N.Y.H., Gouma, D.J.: Risk factors tor bile duct injuries in laparoscopic cholecystectomy: Analysis of 49 cases. Br.J.Surg. $81: 1786,1994$

14) Davidoff, A.M., Pappas, T.N., Muray, E.A., Hilleren, D.J., Johnson, R.D.。 Baker, ME., Newman, G.E., Cotton, P.B., Meyers, W.C.: Mechanisms of najot biliary injury during laparoscopic cholecystectomy. Ann. Surg. 215:196, 1992

15) Bismuth, H.: Postoperative strictures of the biliary tract.

In The Biliary Tract, J.H. Blumgart, editor, Clinical Surgery Intemational Edinburgh, Churchill-Livingstone, 1983, Vol 5, pp. 209-218.

16) Branum, G., Schmiti, C., Baillie, J., Suhocki, P. Baker, M., Davidoff, A., Branch, S. Chari, R., Cucchiaro, R., Murray, E., Pappas, T., Cotton, P., Meyers, W.C.: Management of major biliary complications after laparoscopic cholecystectomy. Ann. Surg. 5:532, 1993

17) Soper, N.J., Wayne, M., Brunt, M., Stockmann, P.T., Sicard, G.A., Picus, D., Edmundowicz, A, Aliperti, G.: Diagnosis and management of biliary complications of laparoscopic cholecystectomy. Am. J. Surg. 165:663, 1993

18) Huang, S.M., Wu, C.W., Hong, H.T., Ming-Liu, K.L., Lui, W. Y.: Bile duct injury and bile leakage in laparoscopic cholecystectomy. Br. J. Surg. 80:1590, 1993

19) Terblanche, J., Allison, H.F., Northover, J.M.A.: An ischemic basis for biliary strictures. Surgery $94: 52,1983$

20) Davids, P.H.P.* Ringers, J., Rauws, E.A.J., de Wit, Th., Huibregtse, K., van der Heyde, M.N., Tytgat, G.N.J.: Bile duct injury after laparoscopic cholecystectomy: The value of endoscopic retrograde cholangiopancreatography. Gut 34:1250, 1993 



\section{CHAPTER 7}

Injuries of major vessels and bowel during 10.000 laparoscopic cholecystectomies in The Netherlands

Schol F.P.G., Go P.M.N.Y.H., Gouma D.J.

Surg.Endoscopy, in press. 



\section{Abstract}

The aim of this study was to determine the incidence of laparoscopic related major complications such as injuries of major vessels and bowel during laparoscopic cholecystectomy in The Netherlands. Common factors for the aetiology of these injuries, their treatment and outcome were determined. The patient charts of 15 identified laparoscopic related major complications from 2 successive national surveys of 9866 laparoscopic cholecystectomies were analysed. Nine vascular injuries, 5 bowel perforations and $\mathbb{1}$ combined vascular/bowel injury occurred. The cause of the injury was in 6/15 a shielded safety trocar, in $6 / 15$ a Veress needle, in 2/15 possible electrosurgical and in 1/15 an unprotected trocar. The vascular injuries were repaired by simple suturing (7x), patch angioplasty only $(\mathbb{x})$ or combined with an end-to-end anastomosis (1x). The bowel injuries were repaired by simple suturing ( $1 \mathrm{x}$ ), partial bowel resection only $(3 \mathrm{x})$ or combined with deviating stomata $(1 \mathrm{x})$. The combined vascular/bowel injury was repaired by suturing. Postoperative complications occurred in $4 / 15$ patients of which 1 died.

Conclusion: The incidence of major vessel and bowel imjuries during laparoscopic cholecystectomy is $0.15 \%$ in The Netherlands. A majority of these laparoscopic related injuries are caused by a Veress needle or (safety shield) trocar. Lean patients are especially prone for such complications operated by surgeons with little experience in laparoscopic cholecystectomy.

\section{Introduction}

The laparoscopic cholecystectomy is currently the method of preference in The Netherlands to treat symptomatic cholelithiasis. The introduction of this procedure is leading to a general surgical interest in laparoscopy. Besides all the good things, specific laparoscopic related complications start to occur. These major complications are well known from gynaecological literature ${ }^{1,23}$. They include major vascular injuries and bowel perforations. Other major complications such as bile duct injuries are more related to the cholecystectomy procedure itself and have been the subject of earlier studies ${ }^{4,56}$. Because a rapidly increasing number of laparoscopic cholecystectomies are performed in the Netherlands, the laparoscopic related major complications are now also becoming apparent.

The aim of this study was to determine the incidence of major vessel and bowel injuries 
during laparoscopic cholecystectomy in The Netherlands and to evaluate common denominators for the aetiology of these injuries, their treatment and outcome.

\section{Materials and Methods}

A national written survey covering a period from spring 1990 until April 1992 and an additional national survey from April 1992 until January 1993 revealed 15 laparoscopic related major vessel and bowel injuries in 9866 laparoscopic cholecystectomies performed in The Netherlands. These injuries occurred in 14 surgical institutions throughout the country. Each case was analysed individually by assessing patient charts and interview of the surgeons inwolved.

Sex, age, Quetelet index and indication for the laparoscopic cholecystectomy of the patients with a major complication were determined. Prior abdominal operations were noted. To detect common factors in the cause of the major complications, specific procedure related actions such as establishing pneumoperitoneum and insertion of the periumbilical trocars were analysed. The type of instruments used were noted. The treatment and outcome of the major complications were evaluated.

Finally, the number of laparoscopic approaches performed by the surgeons at the moment the complicated laparoscopic cholecystectomy occurred, was established.

\section{Results}

Both national surveys had a compliance of $100 \%$ respectively $76 \%$ after additional phone call. With 15 laparoscopic related major complications the incidence ratio was $0.15 \%$.

The results of the analysis of the 15 patients with major laparoscopic related complications that occurred during laparoscopic cholecystectomy are summarised in table 1.

The median age of the patients was 44 (range 16-80) years. In 12 patients it was possible to determin the Quetelet index: 7 patients were considered lean (index $\left.\leq 20 \mathrm{~kg} / \mathrm{m}^{2}\right), 2$ patients were average $\left(21 \leq\right.$ index $\left.<25 \mathrm{~kg} / \mathrm{m}^{2}\right)$ and 3 were considered adipose (index $\geq$ $25 \mathrm{~kg} / \mathrm{m}^{2}$ ). The indication for operation was in all cases symptomatic cholelithiasis. Two patients had a history of prior lower abdominal surgery. In all patients pneumoperitoneum was established with a Veress needle inserted in the periumbilical region. The first trocar was inserted in the periumbilical region without visual guidance. The other trocars were all inserted under control of the endoscopic camera. 


\begin{tabular}{|c|c|c|c|c|c|c|}
\hline ㅊำ & $\begin{array}{l}\text { Quetele } \\
\text { index }\end{array}$ & Injury & $\begin{array}{c}\text { Momeat of } \\
\text { detemtion }\end{array}$ & Cruuse & Type of repair & $\begin{array}{l}\text { Complitications } \\
\text { after repats }\end{array}$ \\
\hline 19 & 19.5 & aorta abdoninalis & at Haparoscopy & saretly trocar & patch angioplasty & - \\
\hline 29 & 20 & aoric branch & at laparoseopy & Veress needle & sutaring & 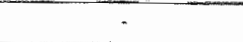 \\
\hline $3 \%$ & - & aortic branch & delayed & Veness needie & suturing & . \\
\hline 48 & 19 & iliac artery & al laparosicopy & Veress needle & suturing & - \\
\hline 58 & 21 & iniac antery & al laparoscopy & Feress needle: & suthering & $\cdot$ \\
\hline $6 \%$ & 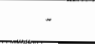 & illiac vein & delayed & Veress netedle & suturitug & - \\
\hline 79 & 17 & Hliac wein & at lataparoscopy & safety trovar & situring & - \\
\hline$B 8$ & 19.5 & ifrac vein & at lanarnscopy & safety trocar & sturing & - \\
\hline 98 & 20 & $\begin{array}{l}\text { iliac veon }+ \\
\text { illac artery }\end{array}$ & at laparoscopy & satety trowar & $\begin{array}{l}\text { palch angloplasty } \\
\text { + end towend } \\
\text { anastomosis }\end{array}$ & Hrombesis femoral vein \\
\hline 108 & 20 & ileum & at laparoscopy & safety trocar & wedge resection & - \\
\hline 116 & 22 & colon transwersum & after conversion & Veress nedle & suturing & sepric, died \\
\hline 12 & 27 & colon transverstatch. & delayed & unproteched trocar & colostoma & crardine arrest \\
\hline $130^{*}$ & - & colon transversuin & delayed & electrosurgical? & hernicolectorny & - \\
\hline $14 \%$ & 37 & $\begin{array}{l}\text { coecum }+ \\
\text { colon transversum }\end{array}$ & delaysed & dectrosurgical? & $\begin{array}{l}\text { hervicolectomy \# } \\
\text { iloostoma }\end{array}$ & $\cdots$ \\
\hline 15 d & 26.5 & $\begin{array}{l}\text { caval vein } \\
\text { jejunum }\end{array}$ & at laparoscopy & saffety trocar & suturing & peritonitis \\
\hline
\end{tabular}

Table 1. Outline of results of major laparoscopic related complications which occurred during laparoscopic cholecystectomy.

In $7 / 9$ patients (no. $1,2,4,5,7,8,9$ ) the vascular injary was detected during the laparoscopic approach and immediately converted to a laparotomy because of retro- or intraperitoneal bleeding visualized by the endoscopic camera. In $2 / 9$ patients $($ no. 3,6$)$ the wascular injury was delayed detected a few hours after the laparoscopic approach because of a blood pressure decrease and laparotomy was performed immediately. The vascular injury of these 2 patients is probably caused by a Veress needle lesion for these injuries were small. In addition the surgeon of patient 6 recalled for difficulties with the veress needle introduction due to adhesions. Only patient 9 with the combined illac artery/vein injury developed a thrombosis of the femoral vein. He was successfully thrombectomized 4 days after initial repair. 
The illeum injury of patient 10 was detected during the laparoscopic cholecystectomy. After conversion to laparotomy it was successful repaired by a small wedge resection. Patient 11 had a colon transversum injury detected after conversion because 3 Veress needle attempts failed due to adhesions after a previous chollecystitis. After repair by suturing, the patient became septic and anuretic and died within a few days. At autopsy the suture was of good quality and a large retroperitoneal non-Hodgkin lymphoma was noted. Patient 12 became septic 2 days after the laparoscopic approach. Faecal discharge occured from an intrabadominal drain left because of a tear in the galbladder during the laparoscopic cholecystectomy. At laparotomy this patient had a perforation in the colon transversum and a grade III peritonitis. A diverting colostoma was made. The surgeon. assumed that the bowell perforation was caused by an unprotected trocar insertion in the upper abdomen. Postoperatively this patient was $9 x$ reoperated to rinse the abdominal cavity. She had also a cardiac arrest that resulted in a temporary partial neuropalsy. The colostomy was reanastomosed and the patient fully recovered after 16 months. Patient 13 developed ileus after laparoscopic cholecystectomy. Three weeks after the laparoscopic approach the patient became septic and laparotomy revealed an encapsulated abscess at the site of a perforation in the hepatic flextre of the colon. A right hemicolectomy was performed and the patient recovered. The Veress needle and trocar insertion were smooth. The involved surgeon considered electrosurgery as the cause of the injury. Patient 14 developed signs of a peritonitis in the right upper abdomen. At laparotomy 9 days after the laparoscopic cholecystectomy a biliary peritonitis due to a small injury in the cystic duct was diagnosed. The cystic duct lesion was repaired and the peritonitis drained. Postoperatively, the patient became respiratory and renal insufficient because of a multi organ failure and was referred to an other hospital for dialysis. In this hospital a secondary laparotomy was performed 4 days later, because of ungoing sepsis. A faecal peritonitis was found due to a perforation in the colon transversum and coecum. A right hemicolectomy with ileostomy was performed. After 7 months the bowel continuity was restored and the patient recovered completely. The colon injury was probably caused by electrosurgery because of late onset of clinical signs of peritonitis.

Patient 15 with the combined vascular/bowel injury was converted to laparotomy during the laparoscopic approach because of blood pressure decrease and blood loss in the lower abdomen after introducing the first umbilical safety shield trocar. At laparotomy a caval 
vein and 2 jejunum injuries were found. Six days after repair a secondary laparotomy was necessary because of a peritonitis due to a non-prior observed third jejunum perforation. After this repair the patient recovered completely.

At the moment of the complicated laparoscopic cholecystectomy 11 surgeons had an experience of less than 20 approaches.

\section{Discussion}

Surgeons in The Netherlands form a coherent group in a relatively small country. Current discussions on safety issues of laparoscopic cholecystectomy encourages them to join surveys on complications. Therefore an incidence ratio of $0.15 \%$ of major laparoscopic related complications in the participating surgical units reflects the actual Dutch situation.

Almost all surgeons, who started the laparoscopic cholecystectomy had an intensive training in laparoscopy in an animal lab and were proctored during their initial procedures. Only injuries of major vessels and bowel perforations were included in this study. This might explain the relatively low incidence ratio for these complications of $0.15 \%$ as compared with other surgical reports $(0.3-0.7 \%)^{7.89}, 10,11$. However, the complication ratio was comparable to the ratio mentioned in the gynaecological literature ${ }^{12,13}$ on major laparoscopic complications. Most major vessel and bowel injuries turned out to be penetrating Veress needle or trocar injuries. It is well recognized that the introduction of these instruments in adipose patients is difficult, because of the lack in "feeling" the instruments penetrating the fascia or too deep insertion. However, most injuries occurred in lean patients. In these patients the distance between abdominal wall and underlying organs is short so that a Veress needle penetrating the abdominal fascia and peritoneum with a little to much force almost immediately hits these tissues. Almost the same problems apply for the insertion of the trocars. There is a widespread belief that a trocar with a safety shield is a safe device for insertion. Most surgeons in The Netherlands use them especially as the first (umbilical) trocar to be placed blindly after esthablishing pneumoperitoneum. In this study $6 / 7$ trocar injuries were caused by a shielded safety trocar. In lean patients the trocar tip already penetrates the peritoneum and punctures intraabdominal or retroperitoneal organs while abdominal wall tissues still withdraw the protective shield ${ }^{14}$. Surgeons must be warned against a misplaced feeling of security by using a trocar with a safety shield. 
In this stries most arterial injuries were caused by a Veress needle. The venous and bowel lestions were mostly caused by trocars. The explanation is probably that the tip of the Veress needle is quite blunt compared to the trocar tip. Therefore the needle does not easily penctrates bowel or veins which will give way. An artery is a more rigid structure and will not give way. In addition, the Veress needle is introduced in the midline of the abdomen with a slight caudal tilting and thus aorta and iliac arteries are anatomically prone to be injured. The insertion of a trocar needs more force than the Veress needle. Because most surgeons are right handed and stand on the left side of the patient, the trocar is often tilted not only a little caudally but also to the right. As the tip of the trocar penetrates first into the abdominal cavity as described above, the bowel, right lliac vein and caval vein are all anatomically in danger. Because the tip of the trocar is razor-sharp these tissues will be perforated easily upon touching. To prevent such injuries, it is important to wait until enough pneumoperitoneum is esthablished (more than 31 in the adult patient) and to pull the abdominal wall firmly ventrally before the Veress needle and sucar are inserted. To have a firm grip on the abdominal wall, it hesps to place 2 grasping forceps on both sides of the umbilical trocar incision instead of grabbing by hand. In difficult or high risk patients an open procedure to bluntly insert the umbilical trocar and subsequently esthablish pneumoperitoneum through the trocar is reconmended ${ }^{15}$. The advantage is that the whole procedure can be performed under visual control and the Veress needle becomes redundant.

Monopolar coagulation is almost exclusively used for hemostasis and dissection in

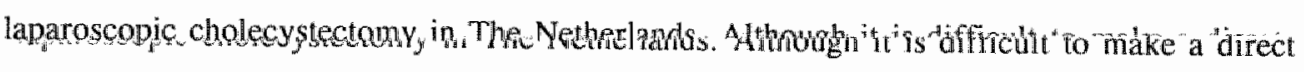
connection, 2 injuries were considered electrosurgical related. Decisive was that both laparoscopic approaches were smoothly and the injuries became symptomatic after more than a week, which is typical for electrical injuries ${ }^{16 .}$

During the analysis, it was found difficult to accurately rank the surgical experience at the time of the complicated laparoscopic cholecystectomy. Therefore the level of experience is arbitrary set at 20 and more. It is not surprising, that surgeons face laparoscopic related major complications more often in the early phase than in the experience phase because a certain feeling for this kind of surgery has to be learned. Therefore emphasis on appropriate and safe Veress needle and trocar application in laparoscopic surgery is necessary to diminish such complications. To achieve this, more attention has to be given 
to the insertion technique of these devices at laparoscopic courses.

Conclusions: The incidence rate of major vessel and bowel injuries during laparoscopic cholecystectomy is $0.15 \%$ in The Netherlands. The majority of these major complications are related to Veress needle and (safety shield) trocar punctures. Especially lean patients are prone for these injuries with surgeons in their early experience phase with laparoscopic cholecystectomy. 


\section{References}

1) Oshnsky, G.S., Smith, A.D. Laparoscopic needles and trocars: An overview of designs and complications. J.Laparoendosc. Surg., 1992, 2: 117-125.

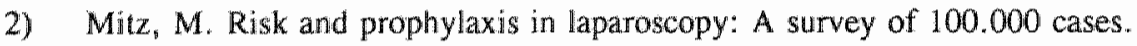
J.Reprod.Med., 1977, 18:269-272.

3) Katz, M., Beck, P., Tancer, M.L. Major vessel injury during laparoscopy: An anatomy of two cases. Am.J.Obstet. Gynecol., 1979, 135: 544-545.

4) Davidoff, A.M., Pappas, T.N., Murray, E.A., and others. Mechanisms of major biliary injury during laparoscopic cholecystectomy. Ann. Surg., 1992, 215: 196-202

5) Schol, F.P.G., Go, P.M.N.Y.H., Gouma, D.J. Risk factors for bile duct unjuries in laparoscopic cholecystectomy: Analysis of 49 cases. Br.J.Surg., 1994, 81: 1786-1788

6) Strasberg, S.M., Sanabria, J.R., Clavien, P.A. Complications of laparoscopic cholecystectomy. Can.J.Surg., 1992, 35“ 275-280.

7) The Southern Surgeons Club. A prospective analysis of 1518 laparoscopic cholecystectomies. N.Engl.J.Med., 1991, 324: 1073-1078.

8) Sim, R.R., Nowicky, D.J., McAlhany, J.C., and others. Laparoscopic cholecystectomy in a community hospital setting. Surg.Gynaecoll.Obstet. „1992, 175: $161-166$.

9) Soper, NJ., Dunnegan, D.L. Laparoscopic cholecystectomy: Experience of a single surgeon. World.J.Surg., 1993, 17: 16-21.

10) Harvey, R. Bernard. M.D., Thomas, W. Hartman, R.A. Complications after laparoscopic cholecystectomy. Am.J.Surg., 1993, 165: 533-535.

11) Lee, V.S., Chari, R.S., Cucchiaro, G., and others. Complications of laparoscopic cholecystectomy. Am.J.Surg., 1993, 165: 527-532.

12) Kehoe, S., Mylotte MJ. 1000 consecutive laparoscopies in gynaecological practice. Ir.J.Med.Sci., 1993, 162:33-36.

13) Chapron, C., Querleu, D., Mage, G., and others. Complications de la coeliochirurgie gynecologique. Etude multicentrique a partir de 7,604 coelioscopies. J.Gynecol. Obstet.Biol.Reprod.Paris., 1992, 21: 207-213.

14) Dunn, D,C., Watson, C.J.E. Disposable guarded trocar and cannula in laparoscopic surgery: A caveat. Br.J.Surg., 1992, 79: 927. 
15) Hasson, H.M. A modified instrument and method for laparoscopy. Am.J.Obstet. Gynecol., 1971, 1.10: 886-887.

16) Levy, B.S., Soderstrom, R.M., Dail, D.H. Bowel injuries during laparoscopy. J.Reprod.Med., 1985, 30: 168-173. 



\section{CHAPTER 8}

Laparoscopic cholecystectomy in a surgical training program

Schol F.P.G., Go P.M.N.Y.H., Gouma D.J., Kootstra G.

Eur.J.Surg., in press. 



\begin{abstract}
Objective: "To evaluate the impact of the introduction of the laparoscopic cholecystectomy on surgical training of residents and to analyse the outcome of laparoscopic cholecystectomies performed by residents compared to surgeons.
\end{abstract}

Design: Retrospective analysis.

Setting: University Hospital

Subjects: 943 patients who were cholecystectomised from January 1987 until Decamber 1993 by residents and surgeons. In 527 patients the cholecystectomy was open and in 416 by laparoscopic technique.

Main outcome measures: Analysis of the percentage cholecystectomies performed by residents in the period 1987 - 1993. Comparison of the outcome of laparoscopic cholecystectomy performed by surgeons and tesidents regarding time of surgery, conversion rate, postoperative complications and hospital stay.

Results: Before the laparoscopic era, on average $70 \%$ of the cholecystectomies were performed by residents. After its introduction in 1990 , the residents performed $38 \%$ of the laparoscopic cholecystectomies in 1991,39\% in 1992 and $64 \%$ in 1993. Statistical analysis showed no difference in outcome of laparoscopic cholecystectomy regarding time of surgery, conversion rate, postoperative complications and hospital stay between surgeons and residents.

Conclusions: The introduction of the laparoscopic cholecystectomy cansed a temporary decline in the number of cholecystectomies performed by residents. The laparoscopic cholecystectomy was integrated as standard surgical procedure in the training program of residents within 2 years after its introduction. The outcome of laparoscopic cholecystectomies performed by supervised residents and surgeons are similar and therefore laparoscopic cholecystectomy should be part of the training of residents.

\title{
Int roduction
}

The cholecystectomy has always been an essential part in the training program of surgical residents. The traditional open cholecystectomy has been replaced by the laparoscopic cholecystectomy and it has become the prefered method to treat symptomatic cholelithiasis in The Netherlands (5). Because of the special skills needed for laparascopic cholecystectomy, a deletion of the cholecystectomy from the surgical training program is 
feared for. Attention is given to the implementation of the laparoscopic techique in the training of surgeons, but little in the training of residents. Laparoscopy forms an integrated part in the training of gynaccological residents, but this program can not easily be copied for surgical training because the procedures differ considerably. A well designed training program for surgical residents is important because the laparoscopic approach can be accompanied with severe major complications due to lack of training or experience as earlier studies showed $(2,6,10)$.

The aim of this study is to determine the influence of the introduction of the laparoscopic cholecystectomy on the number of cholecystectomies performed by residents and secondly, to analyse possible differences in outcome of laparoscopic cholecystectomy between surgeons and residents with respect to tume of surgery, conversion rate to laparotomy, complications and hospital stay.

\section{Patients and Methods}

From January 1987 until December 1993943 cholecystectomies (open and laparoscopic) were performed at the University Hospital of Maastricht. The percentage of totall cholecystectomies anually performed by residents was calculated for open and laparoscopic cholecystectomies.

From its introduction in July 1990 until December 1993416 laparoscopic cholecystectomies were performed by surgeons and residents. All 416 patient charts were studied, to compare the laparoscopic cholecystectomies performed by surgeons and residents. Demografic factors, mean Quetelet index, prior upper abdominal surgery and operation indication were noted. No preselection was made, based on age, Quetelet index, prior stbdominal surgery or operation indication, to determine whether a surgeon or resident would perform the operation. The surgical experience of the residents ranged from 2 to 5 years strgical training. All residents were supervised by an experienced laparoscopic surgeon during the laparoscopic cholecystectomy. A standardised 4 trocar technique was applied in all laparoscopic procedures. Operating time (i.e. total time of the operation as logged by the anaesthesiologist) and time of surgery (i.e. operating time minus the time used for induction of anaesthesia, setup of supportive laparoscopic equipment and extubating after termination of andesthesia as logged by the surgeon) were assessed. Complications during the laparoscopic cholecystectomy, conversion rate to laparotomy, 
postoperative complications, histopathological examination of the gallbladder and hospital stay (including day of admission and discharge) were determined for patients.

\section{Statistical analysis}

An unpaired t-test was used to compare time of surgery between surgeons and residents. With a curve-fit analysis time of surgery of the residents was evaluated. A chi-square test was used to compare the conversion and postoperative complication rate between surgeons and residents. Hospital stay for both groups was compared with an unpaired tutest. Statistical software SPSS $^{*}$ was used. For all tests $p<0.05$ was considered statistical significant.

\section{Results}

The number of cholecystectomies performed by surgeons respectively surgical residents in the years 1987 until December 1993 at our hospital are presented in fig.l.
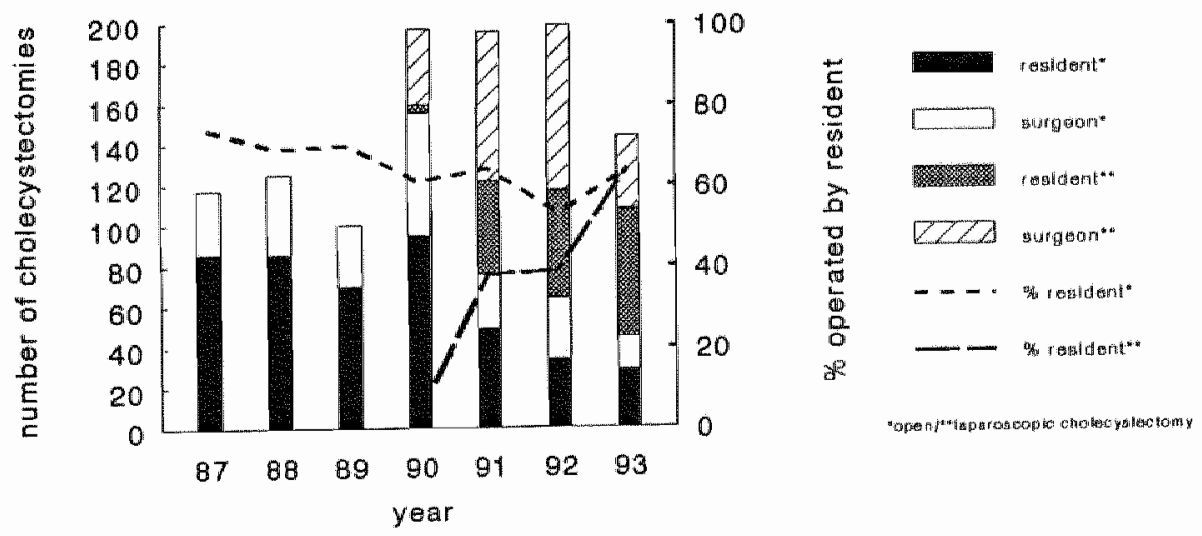

Fig.1. Number of cholecystectomies performed by residents and surgeons for each successive year from 1987 until December 1993. The dotted line indicates the percentage of open or laparoscopic cholecystectomies annually performed by residents. 
Before the introduction of the laparoscopic technique, on average $70 \%$ of the cholecystectomies were performed by residents. During the first 2 years after introduction of the laparoscopie technique in 1991 and $1992,38 \%$ respectively $39 \%$ of the laparoscopic cholecystectomies were performed by residents. In 1993 the residents performed $64 \%$ of the laparoscopic cholecystectomies.

Six surgeons and 12 residents performed 244 respectively 172 laparoscopic cholecystectomies from its introduction in spring 1990 until December 1993. The data comparing patients who underwent laparoscopic chollecystectomy performed by surgeons respectively residents, are given in table 1 and table 2.

\begin{tabular}{|c|c|c|}
\hline Laparoscopic group treated by & Surgeon & Resident \\
\hline number & $\mathrm{n}=244: 680^{x}, 176^{\circ}$ & $\mathrm{n}=172: 380^{m}, 134 \%$ \\
\hline age (mean) & 51 years & 51 years \\
\hline Quetelet index (mean) & $25.6 \mathrm{~kg} / \mathrm{m}^{2}$ & $26.1 \mathrm{~kg} / \mathrm{m}^{2}$ \\
\hline prior upper abdominal surgery & 18 & 11 \\
\hline $\begin{array}{l}\text { operation indication: } \\
\text { symptomatic cholelithiasis } \\
\text { asymptomatic cholelithiasis } \\
\text { congenital spherocytosis }\end{array}$ & $\begin{array}{l}240 \\
3 \\
1\end{array}$ & $\begin{array}{l}172 \\
0 \\
0\end{array}$ \\
\hline $\begin{array}{l}\text { histopathological examination } \\
\text { gallbladder: } \\
\text { acute cholecystitis } \\
\text { chronic cholecystit is } \\
\text { malignancy } \\
\text { no pathology (only gallstones) }\end{array}$ & $\begin{array}{l}11 \\
188 \\
1 \\
44\end{array}$ & $\begin{array}{l}6 \\
148 \\
0 \\
18\end{array}$ \\
\hline
\end{tabular}

Table 1. Comparison for demografic and histopathological data between laparoscop. cholecystectomised groups by surgeons and respectively residents. 


\begin{tabular}{|c|c|c|}
\hline Laparoscopic group treated by & Surgeon & Resident \\
\hline time of surgery (mean) & 71 minutes & 76 minutes \\
\hline $\begin{array}{l}\text { problems encountered during } \\
\text { laparoscopic cholecystectomy: } \\
\text { Veress needle or trocar insertion } \\
\text { insufflation abdomen } \\
\text { infiltration around gallbladder } \\
\text { adhesions } \\
\text { defect of instruments } \\
\text { bleeding eci/a.cystica/hilus } \\
\text { gallbladder perforation } \\
\text { bileleakage cystic duct }\end{array}$ & $\begin{array}{l}69 \text { patients } \\
1 \\
2 \\
18 \\
13 \\
1 \\
1 / 1 / 2 \\
25 \\
5\end{array}$ & $\begin{array}{l}74 \text { patients } \\
4 \\
1 \\
10 \\
11 \\
3 \\
2 / 6 / 8 \\
27 \\
2\end{array}$ \\
\hline $\begin{array}{l}\text { conversion to laparotomy } \\
\text { reason for conversion: } \\
\text { Veress needle or trocar insertion } \\
\text { infiltration around gallbladder } \\
\text { adhesions } \\
\text { intraabdominal bleeding } \\
\text { need for choledochotomy } \\
\text { bile stones intrabdominal }\end{array}$ & $\begin{array}{l}9 \text { patients } \\
0 \\
4 \\
3 \\
1 \\
1 \\
0\end{array}$ & $\begin{array}{l}9 \text { patients } \\
2 \\
4 \\
1 \\
1 \\
0 \\
1\end{array}$ \\
\hline $\begin{array}{l}\text { postoperative complications: } \\
\text { wound infection/bleeding } \\
\text { intraabdominal bleeding } \\
\text { bileleakage transcutaneal drain } \\
\text { pancreatitis } \\
\text { icterus } \\
\text { pneumoniat } \\
\text { ileus } \\
\text { myocardial infarction } \\
\text { death }\end{array}$ & $\begin{array}{l}20 \text { patients } \\
1 / 1 \\
6 \\
7 \\
1 \\
2 \\
1 \\
0 \\
0 \\
1 \text { (myocardial infarction) }\end{array}$ & $\begin{array}{l}19 \text { patients } \\
3 / 2 \\
3 \\
1 \\
3 \\
3 \\
1 \\
1 \\
1 \\
1 \text { (pancreatitis, pneumonia } \\
\text { and cerebral infarction) }\end{array}$ \\
\hline hospital stay (mean) & 4.5 days & 5.0 days \\
\hline
\end{tabular}

Table 2. Comparison between the laparoscopic cholecystectomised groups by surgeons and respectively residents. 
Time of surgery wass 73 minutes compared to operating time 104 minutes. This means, that induction of anathesia, preparing the laparoscopic setup and extubaring after anaesthesia took a mean time of 31 minutes. More experience of the operating staff did not reduce this period. Mean time of surgery of the residents was 5 minutes longer than the surgeons, a difference that was not significant $(\rho=0.44)$. Evaluation of the mean time of surgery for residents during the study period is outlined in fig. 2 .

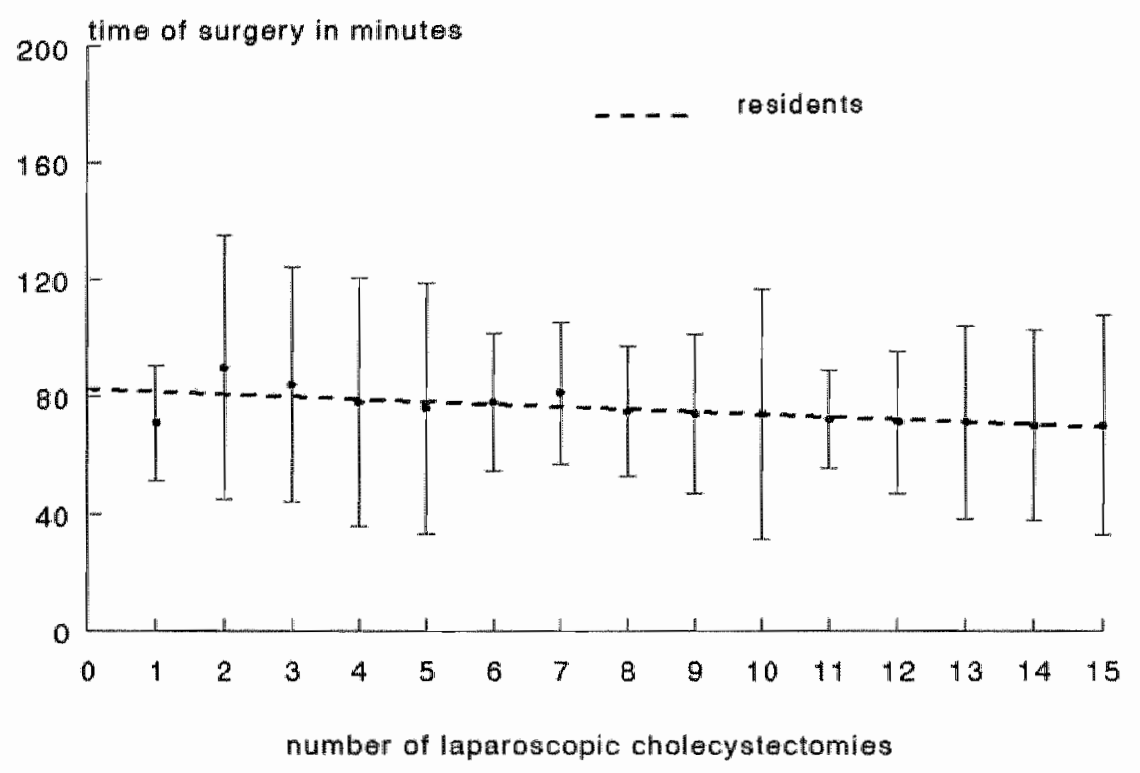

Fig.2. Mean time of surgery ( \pm s.d.) of residents for each consecutive laparoscopic cholecystectomy under supervision of a surgeon. Best curve-fit is $y^{2}=1 / \ln (x)\left(r^{2}=0.69\right)$.

Unclear anatomy encountered by the residents during the laparoscopic approach caused the surgeon in 4 cases to take over the operation from the resident. Both, conversion rate to laparotomy $(p=0.44)$ and postoperative complication rate $(p=0.32)$ were not significantly different for surgeons and residents. Two patients died after a laparoscopic cholecystectomy. One patient, operated by a surgeon, died 20 days after the operation and autopsy showed a massive cardiac infarction. The other patient, operated by a resident, 
died 5 weeks after an acute cholecystectomy which was converted to a laparotony becanse of adhesions. This patient developed a necrotising pancreatitis, an aspiration pneumonia and a cerebral infarction which were confirmed at autopsy. After laparoscopic cholecystectomy 2 patients operated by a surgeon and 3 patients by a resident became jaundiced and an endoscopic retrograde cholangio- pancreaticography was performed. Of the latter, 3 patients had a papillotomy because of common bile duct stones which were succesfully removed. In 2 patients a biliary stent was inserted because of a papil carcinoma in one and a cystic duct leakage in the other. All patients with complications recovered completely from the complication. The mean hospital stay was 4.5 and 5.0 days for surgeons respectively residents which was not statistically different $(p=0.29)$.

\section{Discussion}

Cholecystectomy is considered as an operation with a moderate degree of difficulty and ideal to teach to surgical residents. Before the introduction of the laparoscopic cholecystectomy on average $70 \%$ of all cholecystectomies were performed by residents at the University Hospital of Maastricht. In 1990 the laparoscopic cholecystectomy was introduced. This early introduction induced an increasing number of (extra) regional referrals which led to an increased number of cholecystectomies performed in the 19901993 period. In 1990 only 10\% of the laparoscopic cholecystectomies were performed by residents and the open procedure was performed in $60 \%$ by residents. It is obvious that first the surgeons had to gain experience with the laparoscopic technique before teaching it to the residents. The percentage of residents performing laparoscopic cholecystectomies raised to $64 \%$ in 1993 , which correlates well with the percentage before the laparoscopic era. As the open cholecystectomy is for most residents a basic operation in the training of abdominal surgery, the laparoscopic cholecystectomy can be the same to teach residents laparoscopic surgery. Therefore the cholecystectomy, open or laparoscopically, will remain an operation to be performed by surgical residents in training and has to be included in the training repertoire.

An issue in respect to training is safety and operation time. Teaching can be time consuming. The constant time interval in the operating room before the surgeon or resident actually can start the laparoscopic operation, does not diminish with more experience in laparoscopic procedures, at least in our material. The anaesthesiologist needs a fixed time 
for induction of anaesthesia, but more time is used for training residents and rurses to install all necessary equipment for the laparoscopic approach. Time of surgery was not significantly different for surgeons and residents and is comparable with literature $(1,8)$. There was only small difference in time of surgery for residents between the initial $(1-5)$ laparoscopic cholecystectomies as compared to more experience (10-15) with the laparoscopic procedure, probably because all operations were assisted by an experienced laparoscopic surgeon. Conversion rate and postoperative complication rate were similar for surgeons and residents and in accordance with literature $(1,3,11)$. All these findings indicate, that under the guidance of an experienced laparoscopic surgeon, the resident can be trained to safely perform a laparoscopic cholecystectomy in a time of surgery comparable to the surgeon himself without compromising the quality of health care for the patient. All residents who performed the laparoscopic procedures in this study had prior experience with open cholecystectomy. A new generation surgical residents start their training without this experience. It is not wise to wait with laparoscopic training until these new residents have gained experience with the open cholecystectomy because nowadays most cholecystectomies are performed laparoscopically and only complicated cholecystectomies are performed open. Although most residents attended a laparoscopic teaching course in our facility, training in an animal laboratory to leam laparoscopic operations is in our view not mandatory, because young residents are learning all the time many new surgical techniques in the OR under close proctorship. No commonly performed procedures are trained on animal models first. Training at a skill laboratory to gain experience with the two-dimensional representation of the laparoscopic technique is highly recommended (7), In the near future, computerized simulators with a wirtulal reality system will create extensive laparoscopic training possibilities $(7,9)$. The laparoscopic cholecystectomy can be teached to residents from their second year of surgical training. under the guidance of an experienced laparoscopic surgeon in the same way as the residents learn other surgical techniques. It is obvious, that the teaching surgeon should be confident with the laparoscopic technique, that he or she can anticipate on problems encountered during the procedure performed by the resident. Although no particular number of laparoscopic cholecystectomies can be given before a surgeon is qualified to teach the technique to others, the European Association for Endoscopic Surgery has issued six recommendations for qualification $(4,7)$. 
We conclude that the introduction of the laparoscopic cholecystectomy caused a temporary decline in the number of cholecystectomies performed by residents. The laparoscopic cholecystectomy was integrated as standard surgical procedure in the training program of residents within 2 years after its introduction. The outcome of laparoscopic cholecystectomies performed by supervised residents and surgeons are similar and therefore, laparoscopic cholecystectomy should be part of the training of residents and can function as a basic training for advanced laparoscopic surgery later on. 


\section{References}

1. Atabek U, Spence RK, Pello MJ, Alexander JB, Villanueva D, Camishion RC. Safety of teaching laparoscopic cholecystectomy to surgical residents. I Laparoendosc Surg. $1993 ; 3: 23-26$.

2. Branum $G$, Schmitt $C$, Baillie d, Suhocki $P$, Baker $M$, Davidoff $A$, Branch $S$, Clari $R_{*}$ Cucchiaro $G_{4}$ Murray $E$, Pappas $T$, Cotton $P$, Meyers WC. Management of major biliary complications after laparoscopic cholecystectomy. Ann.Surg. 1993; 217 : $532-541$.

3. Deziel DJ, Millikan KW, Staren ED, Doolas A, Economou SG. The impact of laparoscopic cholecystectomy on the operative experience of surgical residents. Surg Endosc. 1993; 7: 17-21.

4. E.A.E.S guidelines. Training and assesment of competence. Surg Endosc. 1994; 8 . $721-722$.

5. Go PMNYH, Schol FPG, Gouma DJ. Laparoscopic cholecystectomy in The Netherlands. Br J Surg. 1993; 80: 1180-1183.

6. Huang SM, Wu CW, Hong HT, Ming-Liu KL, Lui WY. Bile duct injury and bile leakage in laparoscopic cholecystectomy. Br J Surg. 1993; 80: 1590-1592.

7. Jakimowicz JJ. The European Association for Endoscopic Surgery. Recommendations: for training in laparoscopic surgery. Ann Chir et Gynaecol. 1994; 83: 137-141.

8. Miller RE, Kimmelstiel FM. Surgical laparoscopic experience during the first year on a teaching service. Surg Gynaecol Obstet. 1992: 175: 523-527.

9. Satava RM. Virtual reality surgical simulator, the first steps. Surg Endosc. 1993; 7 : 203-205.

10. Schol FPG, Go PMNYH, Gouma DJ. Injuries of major vessels and bowel during 10.000 laparoscopic cholecystectomies in The Netherlands. Surg Endoscopy in press.

11. Sigman HH, Fried GM, Hinchey EJ, Mamazza J, Wexler MJ, Garzon J, Meakins JL. Role of the teaching hospital in the development of a laparoscopic cholecystectomy program. Can IS Surg. 1992; 35:49-54. 


\section{CHAPTER 9}

Treatment of patients with gallstone disease in the laparoscopic cholecystectomy era 



\section{Introduction}

Patients with gallstone disease are referred for treatment of their gallstone(s) in different clinical stages such as asymptomatic, symptomatic or complicated cholelithiasis. Each clinical stage has its optimal treatment modality. It is therefore important, to select a treatment for each patient based on the clinical stage. A flow chart was designed to help the clinician in this process (fig. 1.). The flow chart gives an overview of the possible treatment modalities for the different stages of gallstone disease and can be used as decision tree. Now the laparoscopic cholecystectomy has been generally accepted, the possibilities of laparoscopic treatment of gallstone disease have been given an important role in this decision tree. It is important to realise, that local expertise or availability of certain techniques will play a central role in the use of the decision tree. If necessary, the surgeon can deviate from the decision tree and choose an other technique or has the option to refer the patient to a specialised center.

\section{Decision tree for treatment of patients with gallstone disease}

The principle of the decision tree is such, thatt all patients with gallstone disease are treated by laparoscopic cholecystectomy unless exclusion criteria are found. The exclusion criteria are summarised in 5 questions. If one of these questions has to be answered affirmative, the patient will follow a side track in the flow chart and initially not eligible for laparoscopic cholecystectomy.

All patients not excluded by one of the 5 criteria above, can undergo a laparoscopic cholecystectomy. In principle, patients excluded by one of the 5 criteria should have an open cholecystectomy. However, surgeons experienced with laparoscopic surgery can perform a cholecystectomy and if indicated a choledochotomy of the initially excluded patients laparoscopically. The threshold for conversion to open cholecystectomy should always be low, to prevent laparoscopic related complications. 
Patients with asymptomatic cholelithasis do not have to be treated.

\section{Suspected bile duct stones}

If bile duct stones are expected because of elevated liver function tests and/or distended bile ducts at ultrasound investigation, it depends on the patient's age which route should be followed. This ange is arbitory set at 50 years. If the patient is 50 years or older, an ERCP and papillotomy followed by a cholecystectomy is recommended. If ERCP fails and for patients youger than 50 years, a cholecystectomy and choledochotomy should be performed to remove the bile duct stones. There is an increasing tendency to perform also an ERCP and papillotomy instead of a choledochotomy in patients younger than 50 years.

\section{Gallstone pancreatitis}

Patients with gallstone pancreatitis are best treated with an ERCP and papillotomy. After symptoms subsided, a cholecystectomy can be performed. If ERCP and/or papillotomy fail, the severity of the pancreatitis determines at which moment the cholecystectomy and choledochotomy can be performed. Patients with mild pancreatitis can be delayed operated. If the pancreatitis becomes more severe, cholecystectomy and choledochotomy should be performed without delay. High risk patients with gallstone pancreatitis should be treated expectatively after ERCP and papillotomy.

\section{Acute cholecystitis}

Patients with a history of acute cholecystitis shorter than I week should have a cholecystectomy early. If the patient's history is longer or infiltration is clearly evident at clinical examination or ultrasound, the cholecystectomy should be postponed until the infiltrate has subsided. About 2-3 months later the cholecystetomy can be delayed performed. High risk patients can be treated with a percutaneous cholecystostomy and cholecystolithotomy or MTBE. If it is not successful, a cholecystectomy should be performed.

\section{Contraindications for laparoscopic chalecystectomy}

Specific contraindications for laparoscopic cholecystectomy consists of inexperience with 


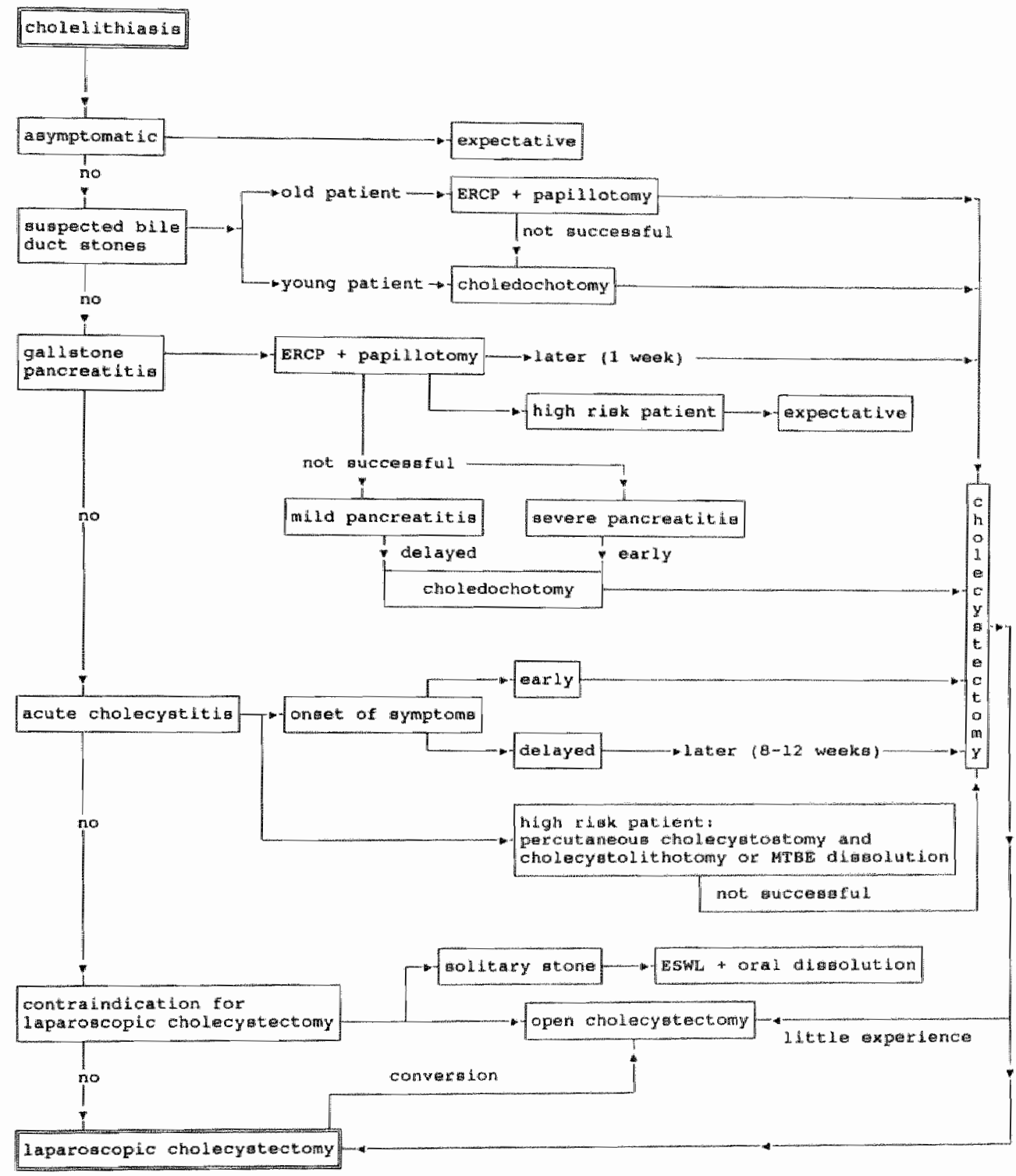

Fig. 1. Decision tree for treatment of patients with gallstone disease. 
the laparoscopic technique, expected lack of anatomical overview due to previous surgery, instrument or other technical failures or patient's preference. These patients should have an open cholecystectomy. In some centers ESWL and oral dissolution therapy is possible for patients with a solutary gallstone. 
CHAPTER 10

Summary / Samenvatting 



\section{Summary}

This thesis was initiated to evaluate the laparoscopic cholecystectomy which has become a generally accepted technique in The Netherlands. Analysis of a new technique in general surgical practice is necessary to evaluate it on its merits. In this thesis the results of laparoscopic cholecystectomy in The Netherlands are analysed from its introduction in spring 1990 until January 1993. Major complications such as injuries of the bile duct, bowel and larger vessels are analysed. Common denominators leading to these complications are identified and evaluated. A second reason to initiate this thesis, was to analyse the implementation of the laparoscopic cholecystectomy on the residential surgical training program.

The current treatment modalities of patients with cholelithiasis in The Netherlands are discussed according to 3 clinical stages in chapter 2. Firstly, asymptomatic cholelithiasis should only be treated in patients with defined high risk on cholelithiasis related complications. Secondly, for patients with symptonatic cholelithiasis, laparoscopic cholecystectomy is the treatment of choice. Alternative treatments for these patients are discussed such as open cholecystectomy, oral dissolution therapy with CDCA or UDCA, dissolving therapy with MTBE, extracorporeal shock-wave lithotripsy and other mechanical direct-contact techniques for fragmentation. Thirdly, complicated gallstone disease is discussed. Patients with an acute cholecystitis should have an early (laparoscopic) cholecystectomy except for longer onset of symptoms. If gallstone pancreatitis occurs, an ERCP and papillotomy should be performed, followed by a laparoscopic cholecystectomy after the symptoms have subsided. If bile duct stones are present, an ERCP with papillotomy, followed by a laparoscopic cholecystectomy is advised for older pattients. For younger patients (laparoscopic) cholecystectomy and bile duct exploration can be considered.

The technique of the laparoscopic cholecystectomy as commonly used in The Netherlands is described in chapter 3. Positioning and intrabdominal introduction of the trocars is explained. The laparoscopic dissection of the gallbladder is discussed and use of the "flag" technique to have a optimal view of the ventral and dorsal anatomical planes of the 
gallbladder hilus is described. The fechnique of the laparoscopic cholangiography is explained and should be performed only if indicated.

The results of 6076 laparoscopic cholecystectomies, which were performed in The Netherlands during the early phase after introduction of the laparoscopic technique from February 1990 until April 1992, are discussed and analysed in chapter 4. These results were obtained by a national survey to all surgical institutions in The Netherlands and a $100 \%$ response was achieved. Conversion rate to open cholecystectomy was $6.8 \%$. Postoperative complications occurred in $4.3 \%$. There were $52(0.86 \%)$ bile duct injuries. Mortality was $0.12 \%$. Average operating time was 70 minutes and average hospital stay was 4.5 days. The results of this general survey are comparable with results from highly specialized centers and overall results of open cholecystectomy, with the exception of the relatively high number of bile duct injuries. The reductions in surgical morbidity and hospital stay will benefit $70-90 \%$ of the patients with gallstone disease ower the next years in The Netherlands.

Thirtyfive hospitals in The Netherlands were personally wisited and the medical charts of the 52 reported patients with bile duct injuries after laparoscopic cholecystectomy were studied. Three injuries reported concerned the cystic duct, so 49 injuries of the bile duct remained to be analysed $(0.81 \%)$. In chapter 5 these 49 bile duct injuries are classified according to a classification proposed by Dr.L.W. Way (University of California at San Francisco, USA). It is hoped for, that this classification for bile duct injuries will be universally used in future studies. The classification is based on operative findings into 4 classes ranging from minor injuries (I, [] and [IIa) to extensive injuries with loss of bile duct tissue (IIIb) or injuries in the liver hilus (IV). Possible risk factors were identified that may contribute to the origin of these injuries. If the bile duct injury was discovered already during the laparoscopic cholecystectomy, the injury was less severe than the delayed detected bile duct injury. Acute cholecystitis and limited laparoscopic experience of the surgeon are contributing factors to the etiology of bile duct injuries. If a bile duct injury is suspected during the laparoscopic cholecystectomy, the operation should be converted for a repair procedure in case enough experience in biliary surgery is present. Otherwise, referral to a specialised center is advised. 
The 49 bile duct injuries described in the latter chapter were repaired by and-to-end or biliodigestive anastomosis. In chapter 6 the results of the repairs of the classified bile duct injuries are analysed. Surgeons preferted end-to-end anastomosis for less severe classified injuries (I, II, IIIa) and the billodigestive anastomosis for more severe classes (IIIb, IV). Three patients treated with a biliodigestive anastomosis after a delayed detected class $\mathrm{I}$, Mnb respectively IV injury died. The 49 repairs had an early stricture rate of $25 \%$ with a median follow up of 134 days. Type of repair and severity of the bille duct injury did not determine the outcome of the repair. Histological proven cholecystitis was predisposing for the occurrence of a stricture at the repair site. It was concluded that end-to-end anastomosis is mostly successful for less severe injuries that were detected during the laparoscopic cholecystectomy. In all other cases this repair can be considered at least as a temporarely internal drainage procedure and a secondary repaim may be indicated after a stricture has occurred. A biliodigestive repair can be best considered as a delayed repair after a drainage procedure has resolved local inflammation.

The patient charts of $15(0.15 \%)$ identified laparoscopic related major vessel and bowel injuries from 2 successive national surveys on 9866 laparoscopic cholecystectomies are examined in chapter 7. The majority of the laparoscopic related injuries were caused by a Veress needle (6/15) or a safety shielded trocar (6/15). In 2/15 possible electrosurgicall and in 1/15 an unprotected trocar caused the injury. The vascular injuries (9) were repaired by suturing, patch angioplasty or combined with an end-to-end anastomosis. The bowel petforations (5) were repaired by suturing or partial bowel resection sometimes combined with a deviating stoma. The combined vascular/bowel injury (1) was sutured. Postoperative complications occurred in $4 / 15$ patients of which 1 died. Patients who are lean by their Quetelet index and surgeons in their early experience phase with laparoscopic cholecystectomy was a special combination for laparoscopic related major injuries.

All 943 cholecystectomies performed by surgeons and residents at the University Hospital of Mastricht from January 1987 until December 1993 were examined. The impact of the introduction of the laparoscopic cholecystectomy on surgical training of residents and the outcome of laparoscopic cholecystectomies performed by residents compared to surgeons were analysed in chapter 8 . In 527 patients the cholecystectomy was open and in 416 
patients laparoscopically. Before the introduction of the laparoscopic cholecystectomy, on average $70 \%$ of the cholecystectomies were performed by residents. After its introduction in 1990, the number of Japaroscopic cholecystectomies performed by residents declined to $38 \%$ in $1991,39 \%$ in 1992 and rised to $64 \%$ in 1993. Within 2 years, the laparoscopic cholecystectomy has become an integrated part of the residential surgical training program. Statistical analysis showed no differences between surgeons and residents regarding the time of surgery, conversion rate to open cholecystectomy, postoperative complications and hospital stay. Thetefore, laparoscopic cholecystectomy should be contimued to be part of the residential training program and can be used as basic skill for advanced laparoscopic surgery.

Treatment of patients with gallstone disease can be difficult and associated with severe complications as showed in the previous chapters. It is therefore essential to choose the optimal treatment for each patient individually. The different treatment modalities for the 3 clinical stages of gallstone disease are outlined in a decision tree in chapter 9. 


\section{Samenvathing}

Dit proefschrift werd geinitieerd on de in Nederland algemeen aanvaarde techniek van de laparoscopische cholecystectomie te evalueren. Analyse in algemeen chirurgische praktijk is noodzakelijk om een nieuwe techniek op haar merites te kumnen beoordelen. In dit proefschrift worden de resultaten van de laparoscopische cholecystectomie in Nederland geanalyseerd vanaf de introductie van deze techniek in de lente van 1990 tot januari 1993. Ernstige complicaties zoals galweg, darm en vaatletsels worden geanalyseerd. Gemeenschappelijke factoren welke tot deze complicaties leiden, worden geidentificeerd en geevalueerd. Een tweede reden tot dit proefschrift was on de consequenties van de introductie van de laparoscopische cholecystectomie voor assistenten in opleiding tot chinurg te analyseren..

Uitgaande van 3 klinische stadia worden in hoofdstuk 2 de huidige behandelings modaliteiten van patiënten met galstenen in Nederland uiteengezet. Patiënten met asymptomatische galstenen moeten alleen behandeld worden als ze tor omschreven risicogroepen behoren warbij er een grotere kans is op complicaties ten gevolge van galstenen. Voor patienten met symptomatisch galsteenlijiden is de laparoscopisclie cholecystectomie de behandeling van keuze. Alternatieve behandelingsmethoden voor deze patiënten worden besproken zoals open cholecystectomie, orale oplostherapie met CDCA of UDCA, oplostherapie met MTBE, extracorporele schok-golf vergruizing en andere mechanische technieken voor fragmentatie van galstenen. Patiënten met gecompliceerd galsteenlijden zoals een acute cholecystitis moeten in een wrote stadium een (laparoscopische) cholecystectomie ondergaan tenzij de symptomen al langer bestatu. Indien een galsteenpancreatitis bestat, is een ERCP en papillotomie noodzakelijk waarna een laparoscopische cholecystectomie kan plaatsvinden zodra de symptomen zijn verminderd. Bij oudere patiënten met choledochusstenen is een ERCP met papillotomie gevolgd door laparoscopische cholecystectomie de beste therapie. Bij jongere patienten daarentegen, moet een (laparoscopische) cholecystectomie met galwegexploratie overwogen worden.

De techniek van de laparoscopische cholecystectomie komt in hoofdstuk 3 aan de orde. 
Positionering en introductie van de trocars worden beschreven. De laparogcopische dissectie van de galblads en de daarbij gebrukte "vlag" techniek, welke dient on een optimaal beeld te krijgen van de ventrale en dorsale amatomische wakken van de galblads, worden uitgelegd. Er is eveneens aandacht voor de techniek van de laparoscopische cholangiografie welke overigens alleen op indicatie verricht moet worden.

De resultaten van 6076 laparoscopische cholecystectomiën welke in Nederland zijn verticht gedurende de vroege fase na introductie van de laparoscopische techniek in februari 1990 tot april 1992, worden in hoofdstuk 4 geanalyseerd. Deze resultaten werden via een nationale enquête bij alle chirurgische klinieken in Nederland verkregen. De respons op de enquête was $100 \%$. In $6,8 \%$ was conversie van een laparoscopische naar een open cholecystectomie noodzakelijk. Bij 4,3\% van de patiënten deden zich postoperatieve complicaties voor. Er waren $52(0,86 \%)$ galwegletsels. De mortaliteit was $0,12 \%$. De gemiddelde operatieduur was 70 minuten met een gemiddelde opnameduur van 4,5 dagen. De resultaten van dit onderzoek zijn vergelijkbaar met de resultaten van gespecialiseerde klinieken en met de resultaten van open cholecystectetomie in het algemeen, met uitzondering van het relatief hoge aantal galwegletsels. In de komende jaren zullen vermindering van chirurgische morbiditeit en opnameduur voor 70-90\% van de patiënten met galsteenlijden in Nederland tot voordeel zijn.

Vijfendertig ziekenhuizen werden in Nederland bezocht om de medische gegevens van de 52 gerapporteerde patienten met cen gahwegletsel na laparoscopische cholecystectomie in re zien. Drie gemelde letsels bleken echter van de ductus cysticus te zijn, zodat 49 letsels van de galweg overbleven om geanalyseerd te worden $(0,81 \%)$. In hoofdstuk 5 worden deze letsels geclassificeerd naar een classificatie volgens dr.L.W.Way (University of California at San Francisco, Verenigde Staten). Er wordt woor gepleit dat deze indeling van galwegletsels ter wille van universaliteit ook in toekomstige studies gebruikt gaat worden. De classificatie is gebaseerd op operatieve bevindingen waarbij 4 klassen te onderscheiden zijn gaande van lichte letsels (I, II en Mla) tot uitgebreide letsels met weefselverlies van de galweg (IIIb) of letsels in de leverhilus (IV). Mogelijke risicofactoren die zouden kunnen. bijdragen tot het ontstaan van deze letsels werden geidentificeerd. Indien een galwegletsel nog gedurende de laparoscopische cholecystectomie werd ontdekt, bleek deze minder 
emstig dan het laat gedetecteerde galwegletsel. Acute cholecystitis en beperkte laparoscopische ervaring van de chirurg zijn bijdragende factoren in de etiologie van galwegletsels. Indien er bij laparoscopische cholecystectomie verdenking is op een galwegletsel moet de operatie geconverteerd worden om een herstel procedure te verrichten indien voldoende kenus van biliaire chirurgie aanwezig is. Zoniet, lijkt verwijzing nat een gespecialiseerd centrum aan te raden.

De 49 galwegletsels uit het vorige hoofdstuk werden middels een end-to-end of biliodigestieve anastomose hersteld. In hoofdstuk 6 worden de resultaten wan deze hersteloperaties van de geclassificeerde galwegletsels geanallyseerd. Chinurgen hadden de voorkeur voor een end-to-end anastomose bilj de minder emstige geclassificeerde letsels (I, II, IIIa) en een biliodigestieve anastomose bij de meer emstige klassen (IIIb, IV).

Drie patiënten zijn met een biliodigestieve anastomose na een laat gedetecteerde klasse II, IIIb respectievelijk IV letsel overleden. De 49 hersteloperaties hadden een vroege strictuur percentage van $25 \%$ bij een mediane follow up van 134 dagen. Type van hersteloperutie en ernst van galwegletsel waren niet bepalend voor het succes van de herstelprocedure. Histologische bewezen cholecystitis was wel predisponerend voor het optreden van een strictuur in het gebied van de hersteloperatie. Een end-to-end anastomose geeft meestal alleen een goed resultaat bij de minder ernstige letsels welke nog gedurende de laparoscopische cholecystectomie zijn ontdekt. In alle andere gevallen moet dit type van herstelloperatie worden beschouwd als een tijdelijke inteme drainage waarna een secundaire hersteloperatie mogelijkerwijze noodzakelijk is als een strictuur ter plaatse van de anastomose ontstaat. Een biliodigestieve procedure moet als een uitgestelde hersteloperatis gezien worden nadat, een drainage procedure de locale ontstekingreactie heeft doen verdwijnen.

De gegevens van $15(0,15 \%)$ patienten, welke met een laparoscopisch gerelateerd letsel wan de grote vaten of darmen gediagnostiseerd zijn in 2 opeenvolgende nationale enguêtes naar 9866 laparoscopische cholecystectomiën, worden in joofdstuk 7 onderzocht. De meerderheid van de laparoscopisch gerelateerde letsels werden veroorzaakt door cen Veress naald (6/15) of trocar met beschermhuls (6/15). In 2/15 was de oorzak mogelik electrochirurgisch en in $1 / 15$ een trocar zonder beschermhuls. De vaatletsels (9) werden 
middels overhechten, patch plastiek of in combinatie met een end-to-end anastomose gerepareetd. Damperforaties (5) werden middels overhechten of partiele darmesectie hersteld warbij soms ook een onllastend stoma noodzakelijk was. Het gecombineerde vatuldarmletsel (1) werd owerhecht. Vier van de 15 patienten hadden postoperatiewe complicaties warbij 1 patient overleed. Patienten, die volgens de Quetelet index mager zijn en chinurgen met weinig ervaring in laparoscopische cholecystectomie bleken een predisponerende combinatie te zijn voor laparoscopisch gerelateerde emstige letsels.

Alle 843 cholecystectomiën, welke door chirurgen en assistenten in opleiding tot chirurg zijn verricht vanaf januari 1987 tot december 1993 in het Academisch Ziekenhuis Maastricht, werden bestudeerd. Het effect wan de introductie van de laparoscopische cholecystectomie op het opleidingsprogramma van assistenten en de resultaten van laparoscopische cholecystectomiën verricht door assistenten vergeleken met de resultaten van chirurgen worden in hoofdstuk 8 geanalyseerd. Bij 527 patiënten werd de cholecystectomie via laparotomie verricht en bij 416 patiẻnten via de laparoscopische procedure. In de periode voor de introductie van de laparoscopische cholecystectomie werden $70 \%$ van de cholecystectomiën door assistenten verricht. Na introductie in 1990 daalde het aantal laparoscopische cholecystectomien door assistenten tot $38 \%$ in $1991,39 \%$ in 1992 en steeg weer tot $64 \%$ in 1993. Binnen 2 jaar was de laparoscopische cholecystectomie een geintegreerd onderdeel van het opleidingsprogramma voot assistenten in opleiding tot chirurg geworden. Er konden na statistische analyse geen verschillen vastgegteld worden tussen chirurgen en assistenten wat betreft operatieduur, aantal converstes natr open cholecystectomie, postoperatieve complicaties en opnamedun. De laparoscopische cholecystectomie dient darom onderdeel te blijen van het opleidingsprogramma en daardoor als basis dienen voor meer geavanceerde laparoscopische chirurgite.

Behandeling van patienten met galsteenlijden kan moeilijk zijn en gepaard gaan met emstige complicaties zoals uit de vorige hoofdstukken blijkt. Het is daarom essentieel, dat voor iedere patiënt individueel de optimale behandeling wordt gekozen. De verschillende behandelingsmodaliteiten voor de 3 klinische stadia van galsteenlijden worden in een beslisboom in hoofdstuk 9 samengevat. 


\section{Dankwoord}

Ik ben alle chirurgen in Nederland, die mij de benodigde gegevens ten behoeve van dit proefschrift zo welwillend ter hand hebben gesteld, bijzonder erkentelijk. In vele gevallen hebben zij ook de tijd kunnen winden om de problematiek van de casus in een persoonlijk gesprek met mij te analyseren. De geweldige medewerking bij dit onderzoek bevestigt volgens mij de eenheid en bereidheid van de Nederlandse chinurgen om innovatieve technieken kritisch op hun merites te beoordelen. Het was voor mij tevens op persoonlijk vlak van bijzondere betekenis om met zoveel verschillende chirurgen door heel Nederland in contact te komen. Ik wil daarom al de chirurgen hartelijk danken voor hun gastvrijheid.

Als volgende wil ik mijn co-promotor dr.P.M.N.Y.H.Go bedanken. Beste Peter, het was jouw enthousiasme, dat me overtuigde, dat een promotie hallbaar was, hoewel ik nog minder dan 2 jaar opleiding te gaan had tot registratie als specialist. Dit enthousiasme zorgde er ook voor, dat ik op wrijwel elk moment van de dag bij je kon binnenvallen voor overleg. Daarbij komt nog, dat ik al gauw merkte dat je een uilzonderlijke gedrevenheid bezit omdat elk geschrift dat ik je ter beoordeling gaf, binnen maximaal twee dagen weer terug was. Hierdoor bleef er een flinke vaart in het proefschrift. Beste Peter, ik ben je blijvend erkentelijk voor alle hulp en adviezen die je mij hebt gegeven gedurende deze jaren.

De bovengenoemde gedrevenheid vond ik ook terug bij mijn promotor Prof.dr.D.J.Gouma. Beste Dirk, elke keer als ik je een hoofdstuk uit het proefschrift ter beoordeling gaf, stond je me in no time met raad en daad bij. De vele discussies welke we onderling en met Peter voerden over elk onderdeel van het proefschrift hadden tot gevolg, dat er duidelijk meer diepte werd bereikt. Ik wil je daarom hartelijk danken voor de intensieve begeleiding bij het tot stand komen van dit proefschrift.

Mijn promotor Prof.dr.G.Kootstra ben ik eveneens bijzonder dankbaar voor zijn adviezen bij de verwezenlijking van dit proefschrift. Beste Gauke, je hebt erg veel bijgedragen door je actieve inbreng in veel hoofdstukken van de these waardoor de kwaliteit is verbeterd. 
Daamaast heb je ook taallkundig talloze verbeteringen aangegeven waarwan ik dankbaar gebruik heb gemaakt.

Mijn collegae wit het Academisch Zjekenhuis Maastricht en het Catharina Ziekenhuis te Eindhoven wil ik danken woor hun hulp en "back up" als ik afwezig was.

Tenslotte wil ik Inge en mijn ouders danken woor hun steun en vertrouwen bij het schrijven van dit proefschrift. 


\section{Curriculum vitae}

Francois Schol was born on March $3^{\text {th }} 1958$ in Amsterdam, The Netherlands. After attending high school in Bilthoven, he entered Medical School in 1976 at the University of Gent, Belgium. After transition to the Medical School of the University of Nijmegen in the Netherlands, he graduated in 1985 .

Within a few months after graduation he started his surgical training at the Catharina Hospital in Eindhoven (head dr.J.Prins). The last 2 years of surgical training were received at the Academic Hospital Mastricht (head Prof.dr.G.Kootstra). During these academic years this thesis was accomplished under the supervision of dr.P.M.N.Y.H.Go and Prof.dr. D.J.Gouma.

Registration as general surgeon followed on January $\mathbb{1}^{\text {th }} 1994$.

Since March $1^{\text {th }} 1994$ he is vascular fellow at the department of vascular surgery of the Catharina Hospital in Eindhoven (head dr.J.Buth). 
Het verschijnen van dit proefschrift werd mogelijk gemaakt door de financiële steun van mijn beicle ouders. 